Portland State University

PDXScholar

Summer 9-30-2019

\title{
Fault Deformation at the Base of and within the Crescent Formation along the Dosewallips River, Olympic Mountains Peninsula, Washington, USA
}

Christine Meryl Maher

Portland State University

Follow this and additional works at: https://pdxscholar.library.pdx.edu/open_access_etds

Part of the Geology Commons

Let us know how access to this document benefits you.

\section{Recommended Citation}

Maher, Christine Meryl, "Fault Deformation at the Base of and within the Crescent Formation along the Dosewallips River, Olympic Mountains Peninsula, Washington, USA" (2019). Dissertations and Theses. Paper 5177.

https://doi.org/10.15760/etd.7053

This Thesis is brought to you for free and open access. It has been accepted for inclusion in Dissertations and Theses by an authorized administrator of PDXScholar. Please contact us if we can make this document more accessible: pdxscholar@pdx.edu. 
Fault Deformation at the base of and within the Crescent Formation along the Dosewallips River, Olympic Mountains Peninsula, Washington, USA

\title{
by
}

\section{Christine Meryl Maher}

A thesis submitted in partial fulfillment of the requirements for the degree of

\author{
Master of Science \\ in \\ Geology
}
Thesis Committee:
Nancy Price, Chair
Ashley Streig
Ray Wells

Portland State University

June 2019 
(C) 2019 Christine Meryl Maher 


\begin{abstract}
The Olympic Mountains, in the cost ranges of northwest Washington, expose a Cenozoic accretionary complex east of the Cascadia Subduction Zone. Accreted material consists of metasedimentary deposits thrust eastward beneath a basaltic terrane (i.e., the basaltic Crescent Formation and the basal Blue Mountain Unit [BMU] turbidite) along a major fault, the Hurricane Ridge Fault (HRF). Recent isotopic dating of zircons from the BMU indicate that it is about 8 my younger than the basalt, implying another major fault may exist east of the HRF, between the BMU and the Crescent Fm. Field observations, data, and samples for microstructural analysis were collected along the Dosewallips River on
\end{abstract} the eastern side of the mountains beginning just west of the HRF, across the fault and BMU, ending about $4.5 \mathrm{~km}$ to the east in Crescent Fm. Evidence for fault-related comminution and frictional melt is present at two locations along the transect: the base of Crescent Fm. and within the Crescent Fm., about $1.6 \mathrm{~km}$ from the base. At the contact between the BMU and the Crescent Fm., there is a damage zone that encloses a $4 \mathrm{~m}$ wide fault, consisting of an increase then drop in fracture density, progression of comminuted material, and the presence of cataclasite and pseudotachylyte. The structure frequency declines to the east for $0.8 \mathrm{~km}$ until our second study site within the Crescent Fm. This outcrop is also notably cut by cataclasite and pseudotachylyte and has a similar increase then drop in fracture density leading to a fault structure, although a fault core has not been identified there. The mineral assemblage in these fault structures includes prehnite, pumpellyite, and epidote, implying that fault deformation occurred at depth along the boundary between the prehnite-pumpellyite and greenschist facies. The fault at the BMU and Crescent Fm. contact, which we name the Ori fault, is a well-developed fault with a 
mappable damage zone and fault core. This supports isotopic age determined hypothesized thrust fault between the BMU and Crescent Fm. The absence of faultrelated deformation between the west and east sites implies two separate fault structures. Overall, evidence from this study suggests primary fault deformation at the contact between the BMU and Crescent Fm. and also within the Crescent Fm. The fault structures documented in this study reveal that along the eastern side of the Olympic Mountains, the Crescent Fm. is more deformed than previously described and that the Siletzia terrane was once seismically active, potentially linked to accretionary processes. 


\section{Dedication}

This thesis is dedicated to Ori, my faithful companion, who has kept me company throughout this entire process, brought light into all of our offices, and whom this fault is named after. 


\section{Table of Contents}

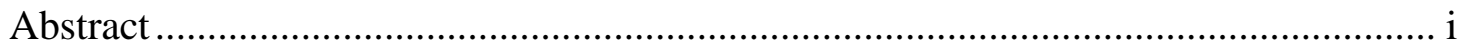

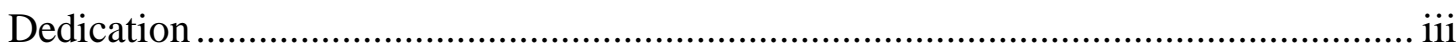

List of Tables ............................................................................................... vii

List of Figures .......................................................................................... viii

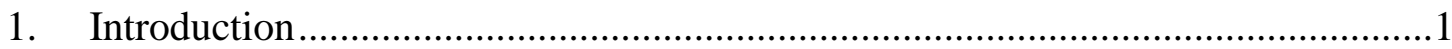

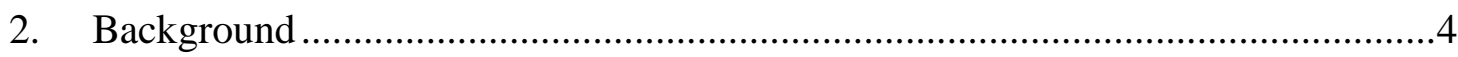

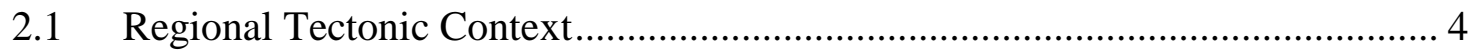

2.2 Rock Units of the Olympic Mountains \& Geologic Setting ............................. 4

2.3 Deformation Structures in the Olympic Mountains ....................................... 6

2.4 Deformation History of the Olympic Mountains .............................................. 8

2.5 Fault Zone Development ...................................................................... 9

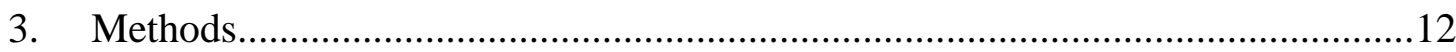

3.1 Outcrop Locations \& Sample Collection ................................................... 12

3.2 Orientation Data Collection and Analysis ............................................. 15

3.3 Fracture Density ............................................................................. 16

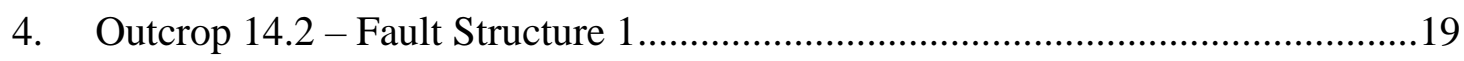

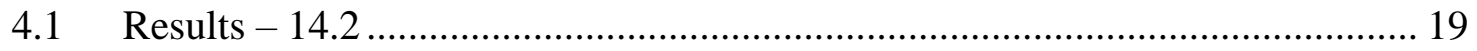

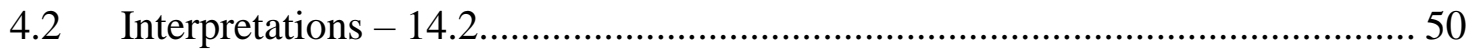

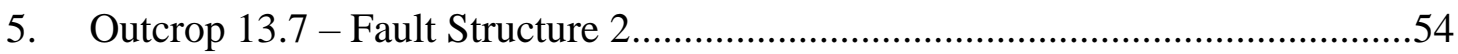


5.1. Results -13.7

5.2. Interpretations -13.7

69

6. Outcrop 15.1 and 14.9 - Metasediments west of the Hurricane Ridge Fault........71

6.1. Results 15.1 - Needle Greywolf Lithic Assemblage .................................. 71

6.2. Results 14.9 - Needles Greywolf Lithic Assemblage ................................... 75

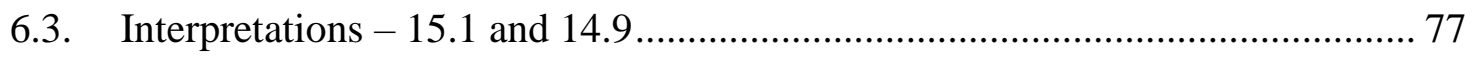

7. Outcrop 11.8 - Crescent Formation ........................................................ 78

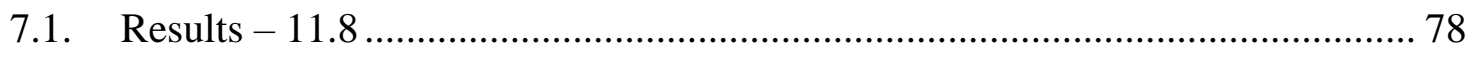

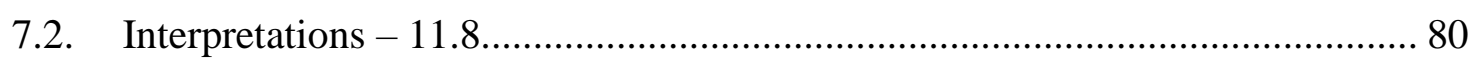

8. Comparison of Sites Along the Dosewallips Transect ...................................82

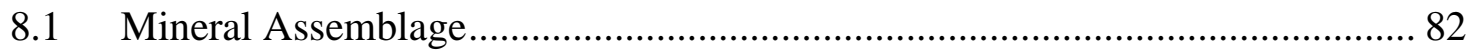

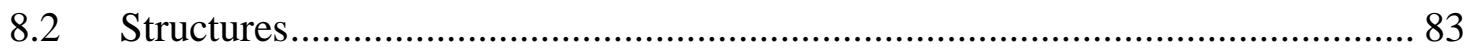

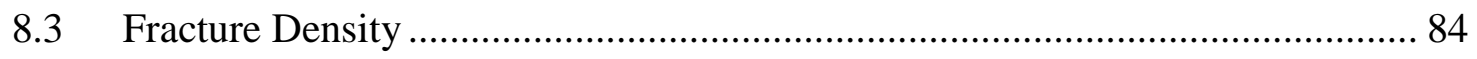

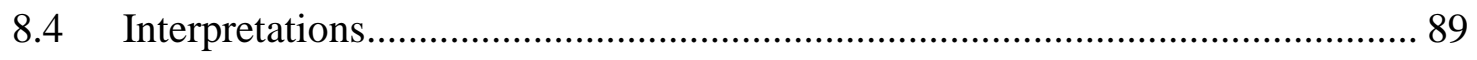

9. Regional Implications and Conclusions....................................................96

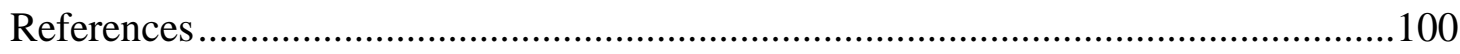

Appendix A - Outcrop Boundary GPS Coordinates .........................................103

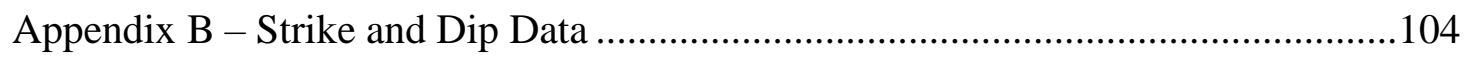

Appendix C - Additional Stereonet Graphs .................................................109 
Appendix D - Additional Fracture Density Data and Graphs

.114 


\section{List of Tables}

Table 3.1. Distribution of outcrop and outcrop subsections along the Dosewallips

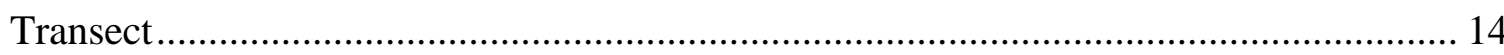

Table 4.1. Summary of the fracture representation planes, the acute angle between them,

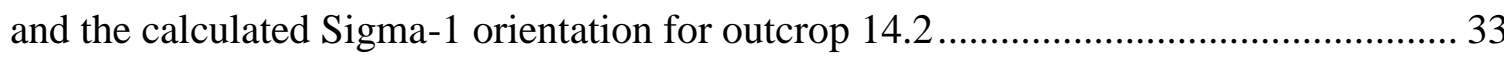

Table 4.2. Fracture density data gathered from outcrop 14.2 that include all counted fractures, NS and EW trending fractures, NS trending fractures, and EW trending fractures.

Table 5.1. Summary of the fracture representation planes, the acute angle between them, and the calculated Sigma-1 orientation for outcrop 13.7

Table 5.3. Fracture density data gathered from outcrop 13.7 that include all counted fractures, NS and EW trending fractures, NS trending fractures, and EW trending fractures

Table 7.1. Fracture density data gathered from outcrop 11.8 that include all counted fractures, NS and EW trending fractures, NS trending fractures, and EW trending fractures 81

Table 8.1. Mineral assemblage from collected samples as listed by outcrop. 82

Table 8.2. Structures observed in outcrop across the Dosewallips transect. 83 


\section{List of Figures}

Figure 1.1. Map of Cascadia Subduction Zone and the Olympic Peninsula. ................... 3

Figure 2.1 Tabor and Cady's four-part deformation history for the Olympic Mountains . 9

Figure 3.1. Geologic map of the study transect and outcrop locations, from the red box in

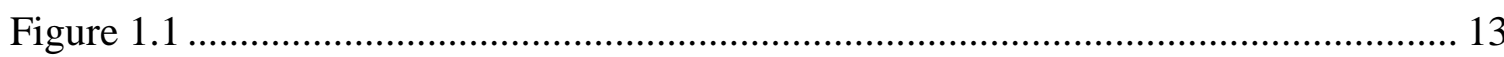

Figure 3.2. Structure from Motion image from outcrop $13.7 \mathrm{G}$ that illustrates how fractures were counted to evaluate fracture density along the transect. ........................ 18

Figure 4.1. Schematic illustration highlighting the structures along outcrop $14.2 \ldots \ldots . . .21$

Figure 4.2. Field images of the main fractures found at $14.2 \mathrm{~A}$ and B ........................ 22

Figure 4.3. Image of fracture gouge for a sub-horizontal fracture at $14.2 \mathrm{~A} \ldots \ldots \ldots \ldots \ldots . . . . . .23$

Figure 4.4. Zoomed in image of lithons from the white box in Figure 4.2A ................. 23

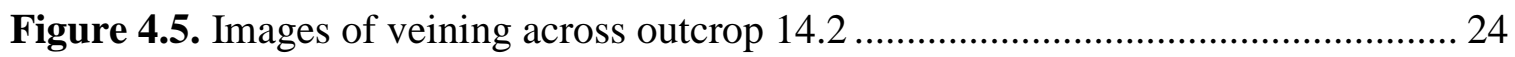

Figure 4.6. Host rock clasts surrounded by black matrix in a vein at $14.2 \mathrm{~B}$................. 25

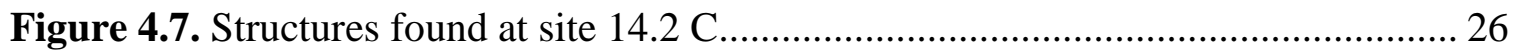

Figure 4.8. Image from the west end of locality 14.2 D, where cross-cutting fractures

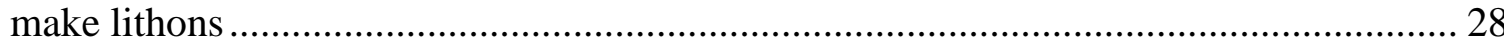

Figure 4.9. Images of the different clast sizes and range of matrix colors at locality

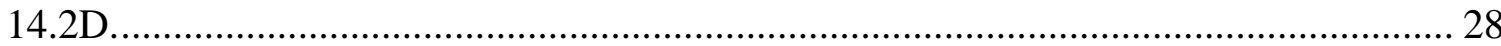

Figure 4.10. Different veins found at 14.2D, all interlayering with the host rock.......... 29

Figure 4.11. Boundary between pillow basalt rich rock and clast supported material .... 30

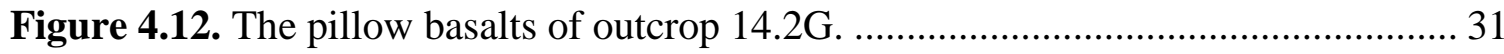


Figure 4.13. Equal area lower hemisphere stereonet of the bedding planes and poles at outcrop 14.2.

Figure 4.14. Equal area lower hemisphere stereonet of the representative fracture planes from each site in the 14.2 outcrop. 33

Figure 4.15. Equal area lower hemisphere stereonet of the vein planes and poles for outcrop 14.2. 34

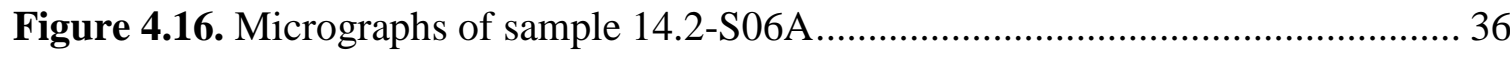

Figure 4.17. Slab scan and plane polarized thin section images of sample DOS14.2207A. 37

Figure 4.18. Backscattered electron images of the edge of a clast in sample DOS14.2S07A. 38

Figure 4.19. Backscattered electron micrograph of distinctly different zones in the matrix of sample DOS14.2-S07A. 39

Figure 4.20. Plane polarized thin section, slab scan, and backscattered electron micrograph images of sample DOS14.2-S09B 41

Figure 4.21. Plane polarized and backscattered electron micrograph images of a sample

DOS14.2-S02B. 42

Figure 4.22. Images from sample DOS14.2-S03A. 43

Figure 4.23. Plane polarized thin section and backscattered electron micrograph images from a sample of the red and green clastic rock from outcrop 14.2D 44

Figure 4.24. Images of sample DOS14.2-S05C A) Slab scan of hand sample 45

Figure 4.25. Images from sample DOS14.2-S05C showing stretched glass grains. 46 
Figure 4.26. Cross polarized thin section images of quartz vein material in samples 14.2S02B (left) and 14.2-S10B (right) showing evidence of quartz bulging in outcrop 14.2. 47

Figure 4.27. SE micrographs of a basalt sample DOS14.2-S011A from 14.2 G showing interlocking grains growing in random orientations............................................. 48

Figure 5.1. Schematic sketch showing the general observable trends throughout outcrop 13.7 55

Figure 5.2. Images showing the difference in the character of fractures along outcrop

13.7. 56

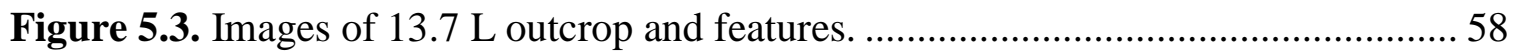

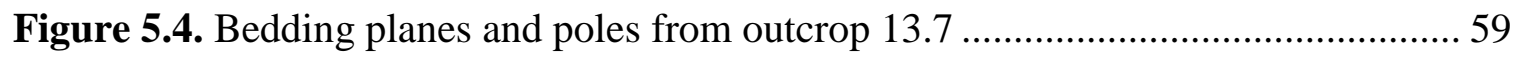

Figure 5.5. Equal area lower hemisphere stereonets of the sectional fracture

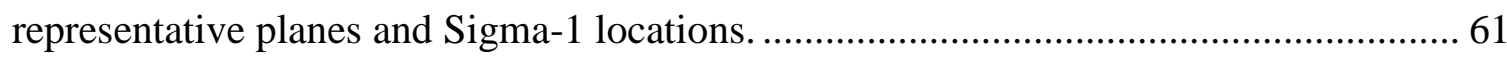

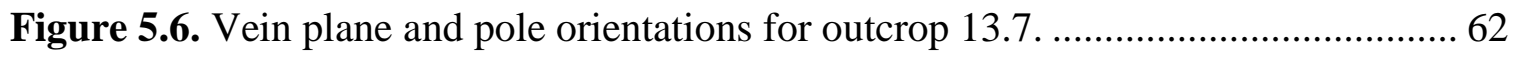

Figure 5.7. Equal area lower hemisphere stereonet showing the collected strike and dip

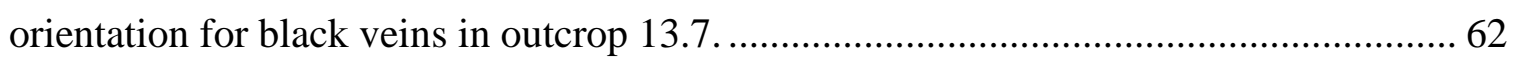

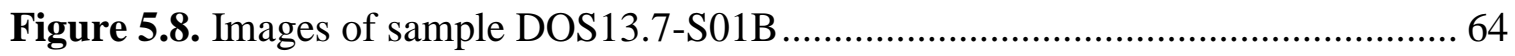

Figure 5.9. Thin section and false colored micrographs of pseudotachylyte from sample

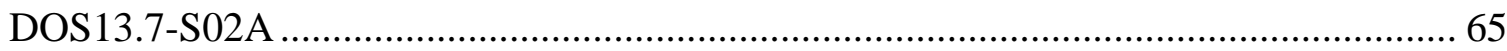

Figure 5.10. Backscattered electron micrograph images of a folded quartz vein in a sample from DOS13.7-S02B 66 
Figure 5.11. Equal area lower hemisphere stereonets of the representative fracture planes, Simga-1 orientations, and interpretative fold axis of fanned Simga-1 orientations

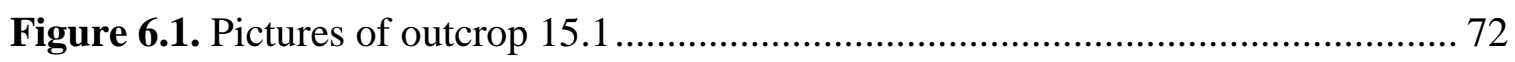

Figure 6.2. Equal area lower hemisphere stereonets of the bedding and fracture data for outcrop 15.1 73

Figure 6.3. Thin section and backscattered electron micrographs of metasedimentary

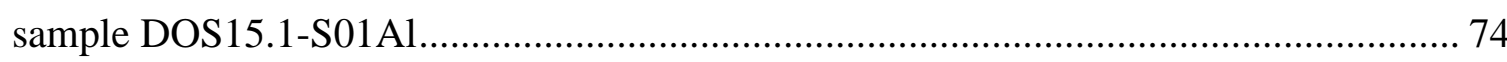

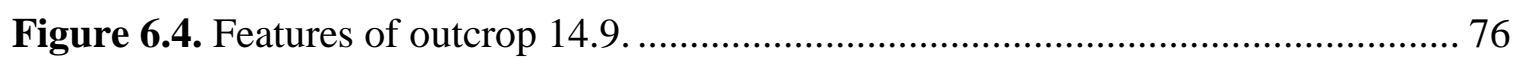

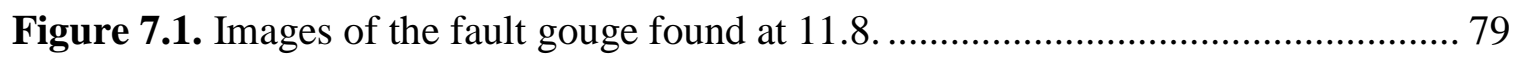

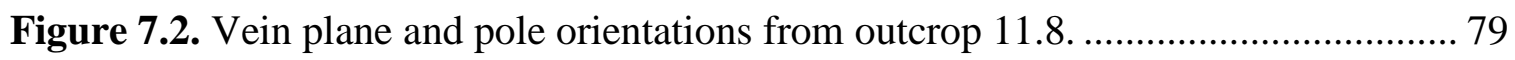

Figure 8.1. Graph illustrating in-situ per meter fracture density. ............................... 84

Figure 8.2. Line graphs showing the Structure from Motion derived fractures per meter

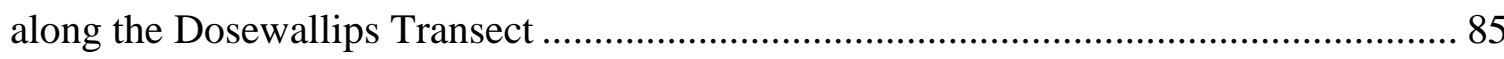

Figure 8.3. Line graphs showing the Structure from Motion derived per square meter

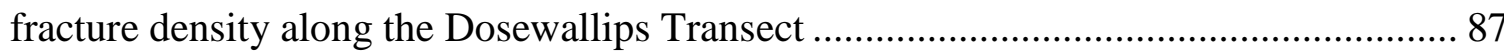

Figure 8.4. Line graphs showing NS and EW trending Structure from Motion per square meter derived fracture density along the Dosewallips Transect ................................... 88

Figure 8.5. Graph comparing the average fracture density of all fracture, NS and EW fractures, and the difference between the two datasets........................................... 88

Figure 8.6. Map and schematic cross sections of the fault structures found along the

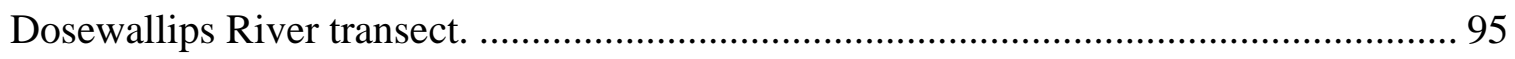


Figure 9.1. Updated structural map of the Olympic Mountains with documented faults and folds...... 


\section{Introduction}

Along the convergent margin of the northwestern US and adjacent Canada, the Juan de Fuca plate subducts northeastward beneath North America along the Cascadia subduction zone (Figure 1.1A). Sediments on the incoming oceanic plate have been scraped off and underthrust beneath the leading edge of North America, producing an accretionary wedge above the subducting plate. In northwesternmost Washington State, structural doming has exposed the accretionary complex onshore, in the Olympic Mountains (Tabor and Cady, 1978a, b; Figure 1.1B).

Within the Olympic Mountains, fault-bounded packages of metasediments are thrust beneath the Crescent Formation, a thick, older accreted terrane of oceanic basalt that has been updomed into a horseshoe shape and forms the structural backstop for the accreted metasediments (Tabor and Cady, 1978a). The Hurricane Ridge Fault (HRF), near the base of the Crescent Formation, is the major terrane bounding fault separating the metasediments from the peripheral forearc rocks. Between the HRF and the base of the Crescent Fm. basalt lies the Blue Mountain Unit (BMU), a lithic turbidite sequence thought to depositionally interfinger with the basalt (Tabor and Cady, 1978a; Gerstel and Lingley, 2003). However, geochronologic data from the northeast and southeast corners of the orogen (Eddy et al., 2017) shows the BMU as approximately 8 million years younger than the Crescent Fm., suggesting the potential for a thrust fault east of the HRF. Preliminary field observations suggest faulting at multiple locations within the Crescent Fm. along the Dosewallips River (Figure 1.1B). This fault deformation has not previously been characterized and its context has not 
been investigated, particularly as it relates to established patterns of deformation with the metasediments (Tabor \& Cady, 1978a, b) or broad fracturing and folding in the basalt (Tabor and Cady, 1978a; Gerstel \& Lingley, 2003).

This project documents the character of deformation across the metasedimentBMU/Crescent Fm. contact with a focused investigation on the locations where evidence of transient seismic slip has been observed. The transect parallels the Dosewallips River trail on the eastern side of the Olympic Mountain peninsula in Washington State, USA. This study finds a collection of fault-related structures leading to a well-developed fault core at the contact between the BMU and Crescent Fm. and another fault structure further east within the Crescent Fm. adjacent to a fractured zone, both structures containing evidence of transient seismogenic activity. These structures add to the established deformation history (Tabor \& Cady, 1978b) and to the regionally mapped structures from Gerstel \& Lingley (2003).

The character and spatial distribution of structures were determined through (a) the field-based collection of orientation data and in-situ fracture density measurements; (b) the investigation of samples using the scanning electron microscope backscattered electron imaging and energy dispersive spectroscopy-based compositional imaging and in-situ analyses; and (c) image-based fracture density measurements using Structure from Motion. 


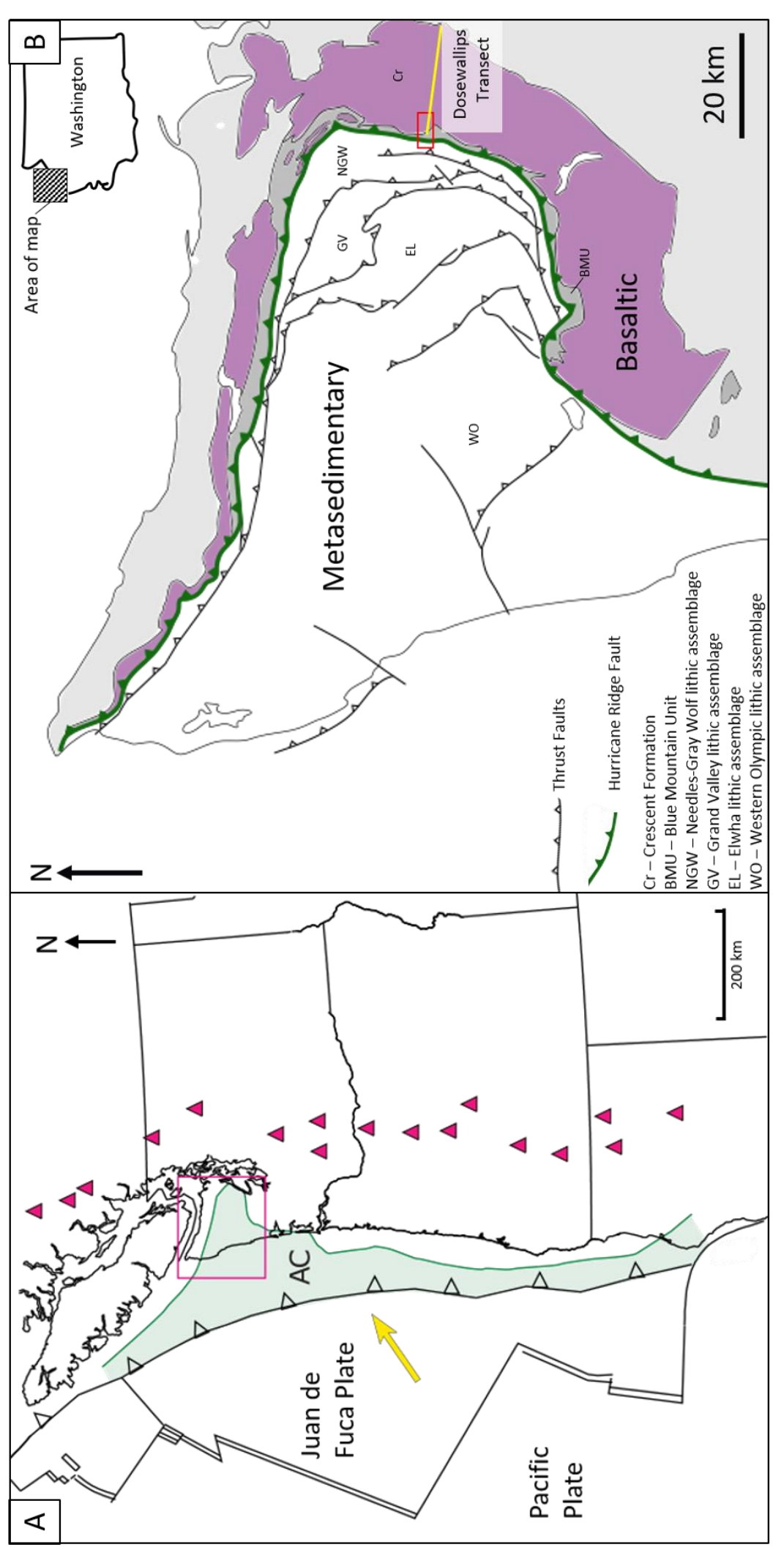

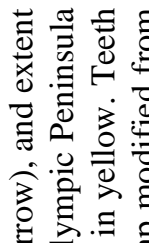

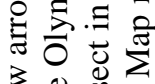

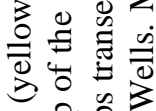

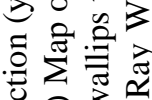

包苞范

ป

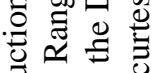

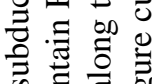

क $\overline{0}$ 元

壳芒离

융 융

玨热苛

¿ U

도

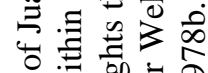

․․ㅎ․

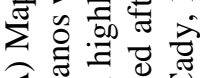

భ

สं

可语完

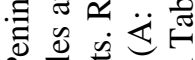

.ำ

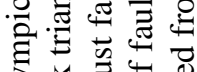

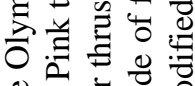

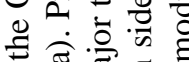

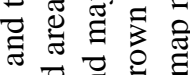

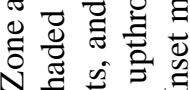

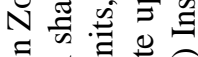

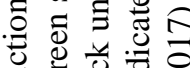

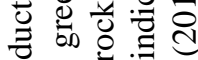

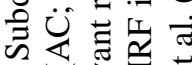

.

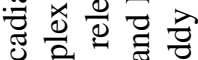

吾 $<$

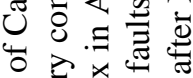

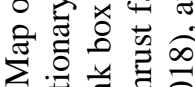

눙

겅

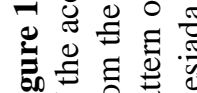

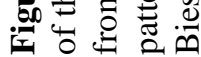




\section{Background}

\subsection{Regional Tectonic Context}

The Cascadia subduction zone accretes material onto North America, creating an accretionary wedge complex, and contributes to microplate rotation within the North American plate, figure 1.1A. Subduction causes SW-NE compression, while the rotation of microplate blocks causes N-S compression in the Olympic Peninsula and extension in the southeast (i.e., the Basin and Range; Wells et al., 1998). These components play a critical role in the development of the Olympic Mountain accretionary wedge and the respective structures observed on the Olympic Peninsula.

\subsection{Rock Units of the Olympic Mountains \& Geologic Setting}

The Olympic Mountains primarily consists of two dominate lithologies: basaltic units to the east that are thrusted over metasedimentary units to the west (Figure 1.1B; white and purple/grey, respectively). Metasedimentary units consist of the Needles-Gray Wolf, Grand Valley, Elwha, and Western Olympic Lithic Assemblages and are predominantly metasandstone and slate that date from Eocene to Miocene epochs (Gerstel \& Lingley, 2003). These are referred to as the Olympic Core Complex by Tabor and Cady (1978b) because they form the structural core of the Olympic Mountains.

The basaltic Crescent Fm. is part of the peripheral rocks that form the north, east, and southern boundaries of the metasedimentary units. The Crescent Fm. is typically divided into upper and lower units, both Eocene in age. The upper unit comprises massive to columnar basalt, and the lower unit comprises densely packed 
pillow basalts (Babcock et al., 1992). The Blue Mountain Unit is a continentally derived turbiditic unit (Einarsen, 1987) that resides between the Needles-Gray Wolf and Crescent Fm. and is typically described as a basal sedimentary deposit associated with the lower Crescent Fm.

The basaltic rocks in the Olympic Mountains are considered part of Siletzia, an accreted oceanic basalt terrane forming the basement of the Oregon and Washington Coast Ranges. There are two hypotheses for the origin of Siletzia, both agree the basaltic unit formed at a rift, but disagree on the location. Duncan (1982) and Wells et al. (2014) suggest that Siletzia formed at the ancient Kula-Farallon mid-oceanic ridge, circa $58 \mathrm{Ma}$, when the ridge moved over the offshore Yellowstone Hotspot in the Pacific basin. The Farallon plate then carried the Siletzia terrane into the Cascadia Subduction Zone and accreted the plateau onto North America (Schmandt and Humphreys, 2011). However, Babcock et al. (1994) suggests Siletzia formed as a rift along the North American west coast.

The Blue Mountain Unit (BMU) and its role at the base of the lower Crescent Fm. is the subject of debate. Until recently, the relationship between the BMU and the Crescent Fm. was defined as depositional (Einarsen, 1987; Gerstel \& Lingley, 2003; Tabor \& Cady, 1978a), where the BMU was the product of continental erosion and deposition during nearby Siletzia volcanism. When the geochronological age of the BMU was compared to that of the Crescent Fm., the BMU was found to have a maximum depositional age as $44.72 \pm 0.21 \mathrm{Ma}$, about $8 \mathrm{~m} . \mathrm{y}$. younger than when Siletzia emplaced between $53.18 \pm 0.17 \mathrm{Ma}$ and $48.364 \pm 0.036$ (Eddy et al., 2017). 
Eddy et al. (2017) proposes that the boundary between the juxtaposed units and age difference is a thrust fault, that puts the older Crescent Fm. on top of the BMU. This fault has possible candidates in the northern parts of the peninsula as the Lower Elwha, Lake Creek - Boundary Creek, and Crescent Faults. The location of the fault along southern parts, such as the Dosewallips River, was defined as uncertain.

The rock units are characterized by burial-driven low-grade metamorphism. The facies gradient ranges from zeolite to lower-blueschist, with the highest-grade rocks near the contact between the metasedimentary units and the Blue Mountain Unit and Crescent Fm. The facies gradient decreases both east and westward from these contacts (Hirsch \& Babcock 2009). Uplift of the mountains exposed the Siletzia terrane and underlying metasedimentary units and fault structures. Exhumation is attributed to isostatic rebound, continuous underplating, and/or compression from microplate rotation (Batt et al., 2001; Tabor \& Cady, 1978b; Wells \& McCaffrey, 2013).

\subsection{Deformation Structures in the Olympic Mountains}

Deformation structures observed in the Olympic Mountain metasediments resemble those expected in an accretionary complex. At the macroscale (i.e., map to outcrop scale), folds and faults tend to orient orogen-parallel. These include the Hurricane Ridge Fault (HRF), which is considered the suture boundary between the metasedimentary core and the Crescent Fm. and BMU of the peripheral rocks (Parsons et al., 1999; Tabor \& Cady, 1978a,b). At the mesoscale (i.e., outcrop to hand sample scale), structure orientations generally mimic the larger scale and show evidence of 
multiple stages of folding and overturned beds (Tabor \& Cady, 1978b). The macroscale structures and their relationship to lithologic units are apparent on the geologic map made by Gerstel and Lingley (2003), and both macro- and meso-scale structures are described in detail by Tabor and Cady (1978b).

Macroscale structures are primarily thrust faults and folds. Figure 1.1B shows a map of the Olympic Mountains and major thrust faults. These faults are map scale, subparallel, mirror the horseshoe-map pattern of the Crescent Fm., and define structural contacts between lithic formations. Although the contact between the Crescent Fm. and BMU is not mapped as a structural boundary, this study and the work by Eddy et al., suggest that is it also a structural contact.

Tabor and Cady (1978b) describe the outcrop to map-scale structures in the Olympic Mountains. The outcrop-scale structures include cleavage, faults, folds, and pencil structures. They state that the dominant structure in the metasedimentary units is cleavage, most prevalent in slaty, schistose, and phyllitic rocks due to the abundance of phyllosilicate minerals. They find that folds are more common in the metasedimentary units than the Crescent Fm., disrupting both thin slate and thick sandstone beds. Many fold hinges were destroyed by shear along cleavage planes. Of the preserved hinges, those in the thicker sandstone layers tend to have round hinges and those in the thinner slate beds tend to have sharp hinges. All the folds range from open to tight. Most of the folds have changing layer thicknesses that indicate flexural flow processes due to differences in layer competency. They interpret that intersecting 
cleavage planes and folded foliations indicate multiple folding events in the metasedimentary core.

\subsection{Deformation History of the Olympic Mountains}

Tabor and Cady (1978) summarized the development of the Olympic Mountain accretionary wedge into a four-part sequence from deposition of the rock units to present day geometry (Figure 2.1). This sequence was based on the interpretation of outcrop-scale structural measurements and observations. In their model, SW-NE compression formed early NW-SE oriented folds, faults, and imbrications (Figure 2.1B and C). This is supported by the orientation of folds preserved at the periphery of the metasediments nearest to the Crescent Fm. (i.e., Domain 12 of Tabor \& Cady, 1978b). Second, the subparallel nature of macroscale fault structures suggests that continued compression pushed the soft sediment against the harder basaltic rocks, molding the Crescent Fm. into a horseshoe shape and pushing the formation into a sub-vertical orientation (Figure 2.1C). This is indicated by the overturned orientations of structures and beds more inland and the steepened folds and faults in the metasedimentary units that parallel the map pattern of the Crescent Fm. The Crescent Fm. constrained the sedimentary rocks and prompted shear folding and doming of the mountain core (Tabor \& Cady, 1978b). This stage is associated with folded folds and secondary cleavage. Finally, Tabor and Cady (1978b) cite isostatic uplift due to the thickened wedge and erosion. 

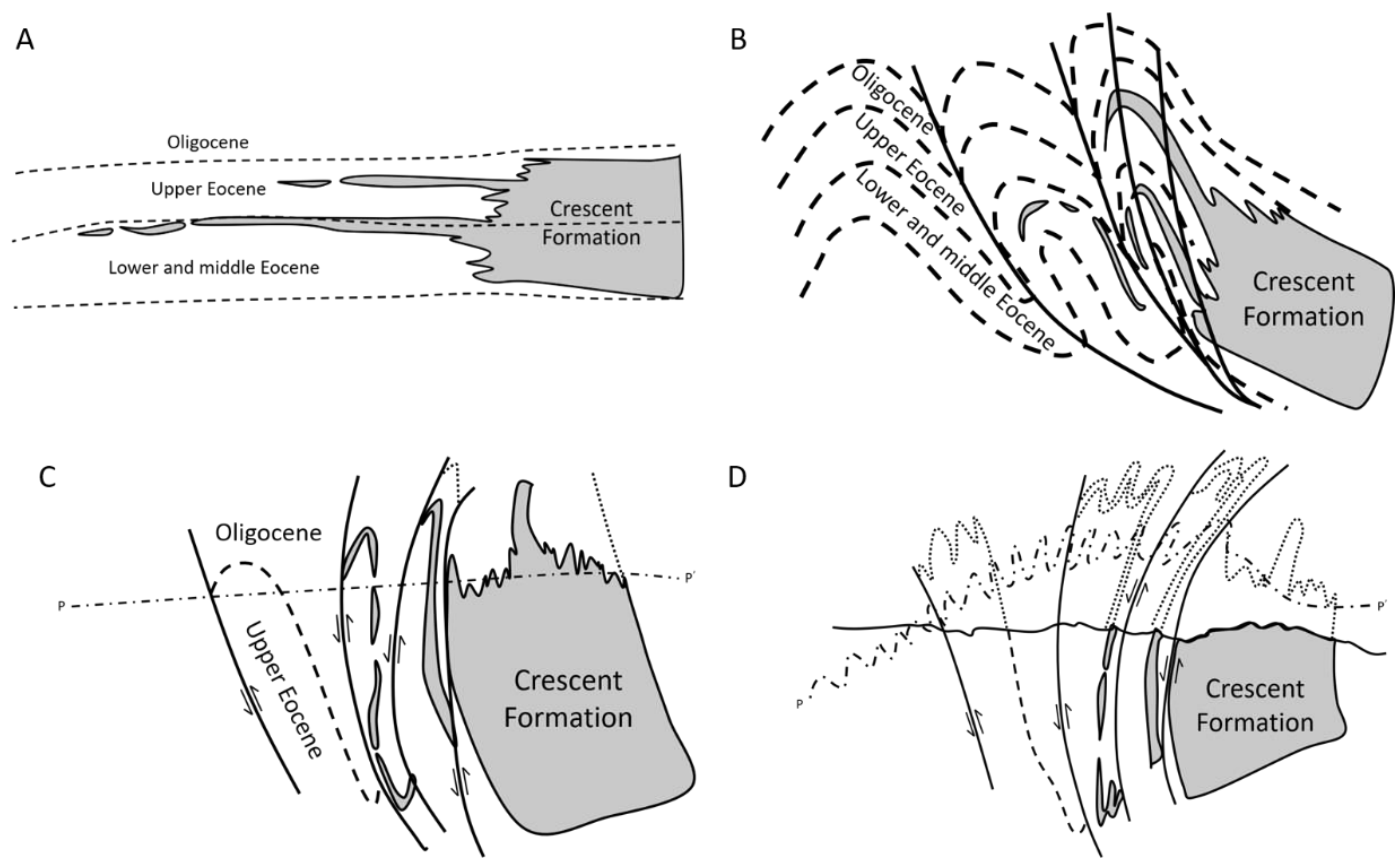

Figure 2.1 Tabor and Cady's four-part deformation history for the Olympic Mountains. The Crescent Formation is shaded in grey and the metasedimentary units are white. Faults are black lines and folds are dashed lines. A) Ages and rock units prior to folding. B) The initial folding and faulting. The Crescent Formation acts as a backstop that the metasedimentary units fold up against. C) The faults steepened into sub-vertical orientations. D) The initial faults overturn due to the wedge thickening and orogenic doming. (Modified from Tabor \& Cady 1978).

\subsection{Fault Zone Development}

Understanding how faults form is critical to investigating the character and spatial distribution of fault-related structures. Lithospheric faults form through the localization and accumulation of strain. Commonly, fault zones develop in two stages (Billi et al., 2003). The first stage is the nucleation and start of the fault through areas of weakness or irregularities (Handy et al., 2007). The second stage is the development of a through-going fault with a damage zone (Billi et al., 2003). The damage zone is distinguished by (a) fractures and smaller faults subparallel to the fault 
core and (b) fault-related structures like fault gouge, cataclasite, and pseudotachylyte (i.e., field evidence of seismic slip) (Choi et al., 2016).

In the first stage of fault zone development, irregularities act as an area of weakness that focuses the formation of initial fractures. Irregularities can be, but are not limited to, preexisting fractures, mineralogical differences, and rough surfaces (Handy et al. 2007). These fractures are the primary structures of the fault's damage zone. Overtime, this damage zone will develop into a strain gradient of dense brittle deformation that stands out from the background deformation, or deformation unrelated to fault zone development (Choi et al., 2016). Fractures eventually connect with other fractures via wing cracks, joint openings, or other connecting structures (e.g., R, P shears). The most fractured part of the damage zone will typically become the weakest part, localizing strain to form the fault core (Kim et al., 2004). This is the second stage of fault formation. Eventually, the majority of strain is taken up within the fault core. Sometimes slip occurs at an accelerated rate, causing an earthquake, and forms cataclasite and pseudotachylyte (i.e., frictional melt) (Lin, 2008). In a welldeveloped fault zone, the end result is a through-going fault that has fractures and smaller-scale faults subparallel to it, a surrounding damage zone, and fault-related structures like fault gouge, cataclasite, and pseudotachylyte (Choi et al., 2016). There is a strain gradient with proximity to the main fault, so these structures are typically most prevalent closest to the fault (Billi et al., 2003).

Cataclasite and pseudotachylyte are the meso- to microscale products of seismogenic faulting. Cataclasite is a highly comminuted rock formed from brittle 
fracturing without melting that contains angular to rounded clasts within a finergrained matrix (Passchier \& Trouw, 2005). Pseudotachylyte is glass that results from frictional melting and rapid cooling (Lin, 2008). Features associated with pseudotachylyte are flow banding, flow folds, injection veins, ladder fracture network, rim halos, devitrified crystals (microlites), and a damage zone of cataclasite (Lin, 2008; Price et al., 2012). Flow banding is the concentration of elements into bands, typically alternating in composition, and flow folds occur where flow bands are folded during frictional slip. Injection veins are the result of melt filling fractures at the edge of the pseudotachylyte vein. Rim halos appear around clasts that were melted in-situ. Devitrified minerals are crystals that grow from the quenched glass. 


\section{Methods}

The methods for this investigation characterize deformation at each outcrop and, where identified, characterize fault deformation. Characterization of outcrop deformation involved identifying rock type via field observations and thin section analysis, and documenting the types and orientation of structures, such as foliations, fractures, and fault structures. Fault-related structures were identified as planar structures with evidence of penetrative, comminution, or frictional melt at the outcrop scale and/or microscale. Orientation measurements were taken to document the representative structure orientation at each outcrop, compare data between outcrops and/or subsections to determine changes along the transect, and compare the orientation of structure types (e.g. the orientation of fault structures vs. the orientation of fracture populations). Fracture density measurements (in-situ and using Structure from Motion) were used to investigate potential damage around identified fault structures. Sample analysis using the scanning electron microscope focused on confirming mineral assemblage and fault deformation (e.g., identifying cataclasite and pseudotachylyte; after Price et al., 2012). The backscatter electron (BSE) was used for imaging and the energy dispersive spectrometer (EDS) was used for in-situ quantitative analyses and qualitative elemental mapping.

\subsection{Outcrop Locations \& Sample Collection}

The study area is located along the Dosewallips River near Brinnon, WA on the eastern side of the Olympic Mountains, figure 1.1. A total of five outcrops were used in this investigation following a transect from the edge of the metasedimentary 
core, across the Hurricane Ridge Fault (HRF), and into the base of the Crescent Formation, three in the Blue Mountain Unit/Crescent Fm. and two within the Needles Grey Wolf lithic package, figure 3.1. Outcrop names are based on their respective distances, in miles, from Highway 101. Outcrops of sufficient size or complexity were further subdivided by letter (e.g., outcrops 14.2, 13.7, and 11.8), with subdivisions set at places where a tree blocks the outcrop or similar natural breaks. The sizes of each lettered subsection are unknown; however, each outcrop is internally continuous (i.e. the subsections are adjacent to each other). Some parts of the outcrops were covered in vegetation, and for these reasons sections 14.2E-F and 13.7 A-D will not be discussed.

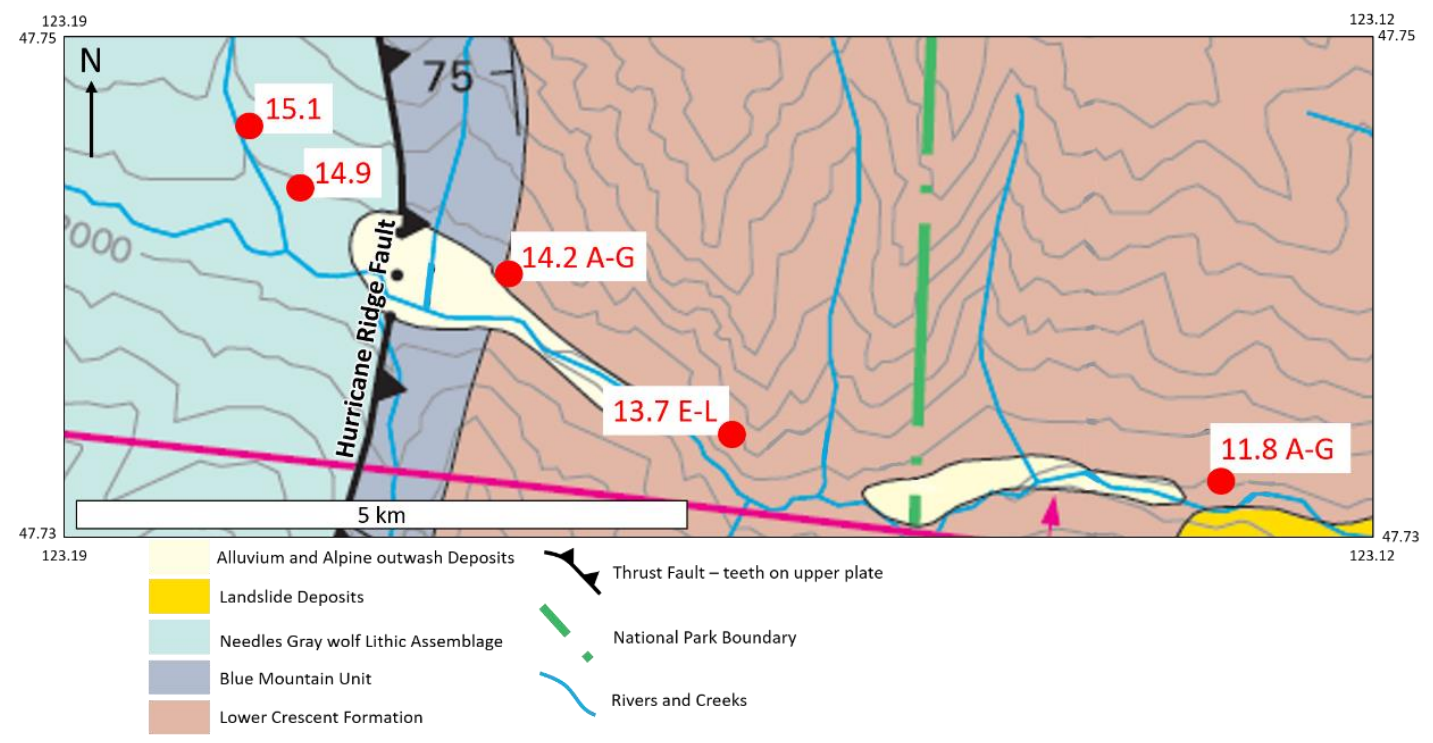

Figure 3.1. Geologic map of the study transect and outcrop locations, from the red box in figure 1.1. Outcrop locations and names are shown by the red dots. Map modified from Gerstel \& Lingley, 2003.

Samples were collected to characterize the mineral assemblage and microscale features of each rock unit. These samples were cut either perpendicular to foliation and parallel to lineation, perpendicular to a planar structure, or in map view. Samples taken only for the purpose of compositional analysis were cut in map view. Additional 
samples were collected along fault structures and veins to investigate microscale faultrelated features and to determine the metamorphic facies of the study area during vein formation. Examples of these samples include comminuted host rock, cataclasite, pseudotachylyte, sheared veins, fault core material, and for comparison, undeformed parent rocks. Fault and vein samples were cut perpendicular to fault orientation, parallel to fault movement (or assumed fault movement); or map view if the rock was not near a fault. Sample names and their respective location within each outcrop subsection are outline in Table 3.1, GPA locations can be found in the appendix (Table A1).

Table 3.1. Distribution of outcrop and outcrop subsections along the Dosewallips Transect. Moving down the table is equivalent to moving from west to east along the transect.

\begin{tabular}{|c|c|c|c|}
\hline Site - Length & Subsection & Rock Unit & Sample Name - Cut \\
\hline 15.1- $1.5 \mathrm{~m}$ & & NGW & DOS15.1-S01 - Perp Foli \\
\hline $14.9-5.75 m$ & & NGW & \\
\hline \multirow{7}{*}{$\begin{array}{l}\tilde{E} \\
\stackrel{\infty}{\infty} \\
\\
\dot{H}\end{array}$} & A & BMU/Crescent Fm. & $\begin{array}{l}\text { DOS14.2-S04 - Map View } \\
\text { DOS14.2-S06 - Perp Foli }\end{array}$ \\
\hline & B & BMU/Crescent Fm. & $\begin{array}{l}\text { DOS14.2-S07 - Map View } \\
\text { DOS14.2-S08 - Map View }\end{array}$ \\
\hline & C & BMU/Crescent Fm. & \\
\hline & $\mathrm{D}$ & BMU/Crescent Fm. & $\begin{array}{l}\text { DOS14.2-S02 - Perp Fault } \\
\text { DOS14.2-S03 - Map View } \\
\text { DOS14.2-S05 - Perp Foli } \\
\text { DOS14.2-S09 - Perp Foli } \\
\text { DOS14.2-S10 - Perp Fault }\end{array}$ \\
\hline & $E$ & Undetermined & \\
\hline & $\mathrm{F}$ & Undetermined & \\
\hline & G & Crescent Fm. & DOS14.2-S11 - Map View \\
\hline \multirow{7}{*}{ 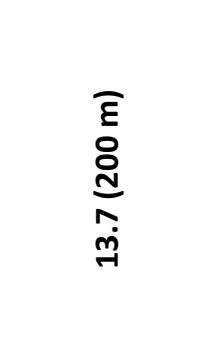 } & $E$ & Crescent Fm. & \\
\hline & $\mathrm{F}$ & Crescent Fm. & \\
\hline & G & Crescent Fm. & \\
\hline & $\mathrm{H}$ & Crescent Fm. & \\
\hline & 1 & Crescent Fm. & \\
\hline & $\mathrm{J}$ & Crescent Fm. & \\
\hline & $\mathrm{K}$ & Crescent Fm. & \\
\hline
\end{tabular}




\begin{tabular}{|c|c|c|c|}
\hline & $\mathrm{L}$ & Crescent Fm. & $\begin{array}{l}\text { DOS13.7-S01- Perp Fault } \\
\text { DOS13.7-S02- Perp Fault }\end{array}$ \\
\hline \multirow{7}{*}{ 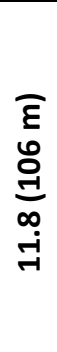 } & $A$ & Crescent Fm. & \\
\hline & B & Crescent Fm. & \\
\hline & $C$ & Crescent Fm. & \\
\hline & $D$ & Crescent Fm. & \\
\hline & $E$ & Crescent Fm. & \\
\hline & $\mathrm{F}$ & Crescent Fm. & \\
\hline & $\mathrm{G}$ & Crescent Fm. & \\
\hline
\end{tabular}

Abbreviations: NGW-Needles Grey Wolf; BMU - Blue Mountain Unit; Perp Foli - cut perpendicular to foliation; Perp Fault - cut perpendicular to fault.

\subsection{Orientation Data Collection and Analysis}

Strike and dip measurements, using right hand rule, were taken along structural features at each outcrop, including; fractures, faults, veins, cataclasite, foliations, and bedding where confidently defined. These data were plotted on a lower hemisphere stereographic projection using the Stereonet 10 program (R. W. Allmendinger et al., 2013; Richard W. Allmendinger, 2018; Cardozo \& Allmendinger, 2013). Structural data was plotted for the entire outcrop and lettered subsections. Representative orientations of measured structures were determined by plotting the poles to the planes, contouring the poles, and then choosing the area(s) with the highest concentration of poles; the plane to that pole is a representative plane for the dataset.

For fracture populations, I found the best representative poles and calculated the orientations of a hypothesized state of stress. If a dataset contained two locations of high concentrations of poles and the angle between the poles was close to that predicted by Anderson's Theory of Faulting (i.e., acute angle of about 35 to 81; Anderson, 1951), the planes were considered as conjugate fractures, or fractures that 
formed coevally under the same state of stress. This is determined by finding the intersection between the two planes (Sigma-2) and the plane to the pole of the intersection, which contains Sigma-1 and 3. Sigma-1, the maximum principal stress, resides in the middle of the acute angle between the two planes. Sigma-3, the minimum principal stress, is 90 degrees from Sigma-1. I compared the predicted Sigma-1 orientations among outcrops and subsections within a single outcrop to determine similarities and differences that may be related to regional tectonic conditions.

For folded rock, the fold axis was determined where the poles of planar structures (e.g., bedding) fit a great circle. In Stereonet 10, the best cylindrical fit function found the girdle to the poles of the planes, which is the representative great circle that best fits the poles. The pole to the girdle is the trend and plunge of the fold axis. This axis represents Sigma-2 of the state of stress in which the fold formed (i.e., assuming coaxial strain). Although it is difficult to determine the orientation of Sigma1 and 3 without field evidence of fold morphology, the state of stress was approximated based on regional tectonics.

\subsection{Fracture Density}

Fracture density was collected using in-situ data collection as the number of fractures per meter and using Structure from Motion (SfM) as the numbers of fractures both per meter and per square meter. In the in-situ method, a 1 meter rope was placed on the outcrop at chest height, or where the outcrop was best accessible, and all the 
fractures that crossed the line were counted. The fractures that crossed the line included outcrop-scale fractures, mesoscale fractures, and en echelon fractures.

SfM data collection involved taking a series of adjacent photographs along each outcrop section, photos are stitched together and used to determine fracture density. Each photograph overlaps the previous, and when stitched together using the SfM program Agisoft, spatial relationships among structures can be analyzed from one image that covers the entire outcrop section. To determine fracture density per meter, a subparallel line was drawn about $1.5 \mathrm{~m}$ above the base of the outcrop. All fractures apparent in the image that cross-cut this line were counted. Where possible, more than one line was drawn per outcrop, and the fracture densities per meter were averaged for one number per subsection. SfM values were directly compared to in-situ fracture counts.

To determine fracture density per square meter using $\mathrm{SfM}, 1 \mathrm{~m}^{2}$ boxes were drawn on the stitched outcrop image and the fractures in the box were counted. To count fractures, each image had multiple sets of boxes in columns, figure 3.2. The base of each column is at the base of the outcrop in the image. Squares were drawn above each other until three boxes were stacked or until no accessible rock was exposed in the image. Columns of stacked boxes were drawn across the outcrop. Since each outcrop and outcrop sections vary in size, the number of squares in each column and the number of columns varied throughout out the transect. The fractures within the square that were apparent at the resolution of the image were counted. This included outcrop scale and mesoscale fractures. A single average fracture density was 
calculated for all grid boxes. For each analysis of fracture density per square meter, I

conducted two types of counts: counting all fractures and counting fractures based on common fracture strike orientation trends. When looking at specific strike orientation fractures, the north arrow on the outcrop was used to determine the fractures relative orientation.

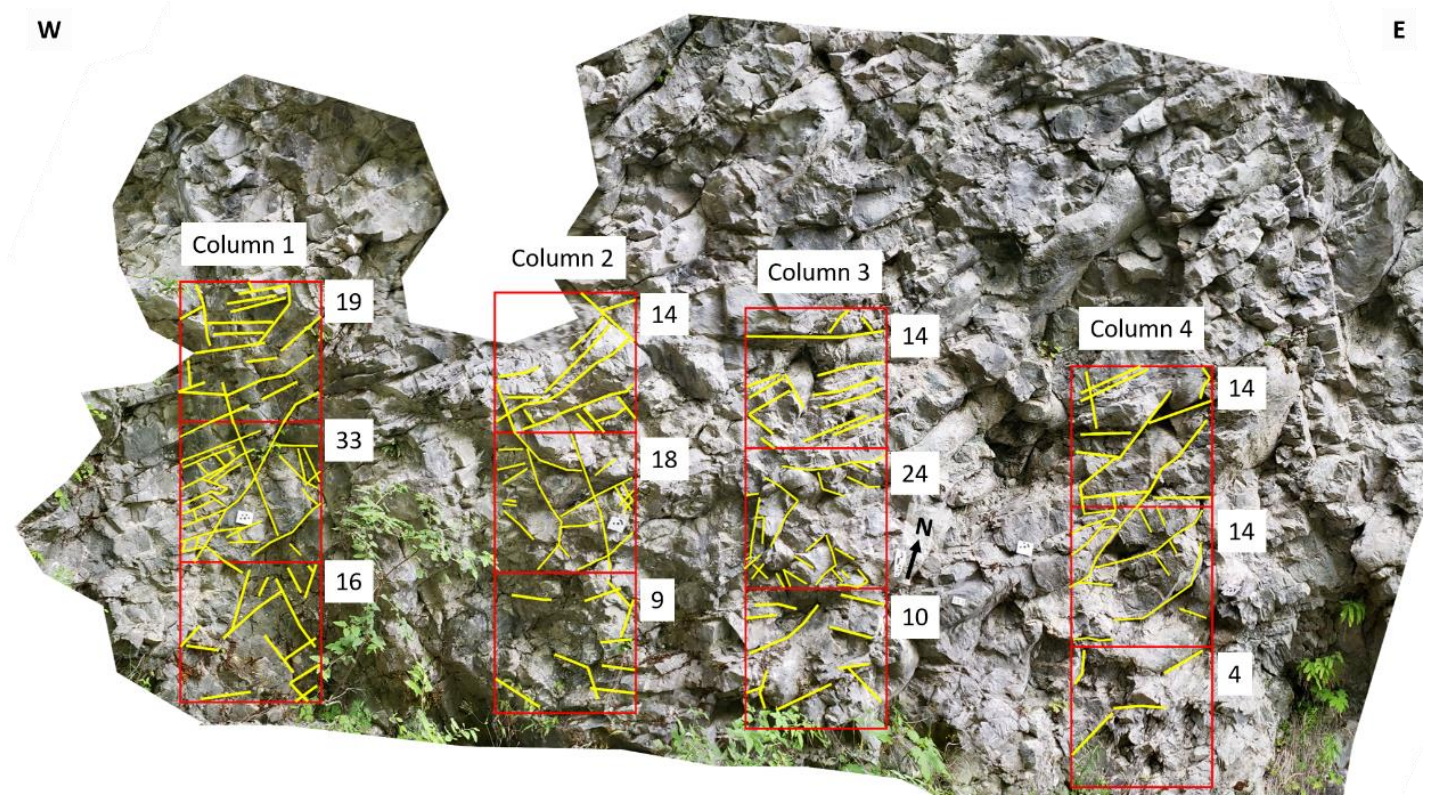

Figure 3.2. Structure from Motion image from outcrop 13.7G that illustrates how fractures were counted to evaluate fracture density along the transect. 


\section{Outcrop 14.2 - Fault Structure 1}

\subsection{Results -14.2}

\subsubsection{Field Observations and Fault-related Structures}

The documentation of the field observations and fault-related structures is summarized in figure 4.1 as a schematic sketch showing major structures, bedding, and their relative locations along the outcrop. Outcrop 14.2 is broken into seven sections A-G. Section A contains the Blue Mountain Unit (BMU), B-D appear to transition between the BMU and the Crescent Fm., E-F are covered in moss and inaccessible, and $\mathrm{G}$ is the Crescent Fm.

\section{$\underline{14.2 \mathrm{~A}}$}

There are two main rock types in this outcrop: fine-grained pillow basalt and a coarse-grained rock with clasts of $2 \mathrm{~mm}-1 \mathrm{~cm}$ in size. The contact between these rocks is irregular between areas that contain pillow basalts within the coarse-grained rock and areas of outcrop scale collections of pillow basalts.

The outcrop is dominated by two apparent fracture populations of subhorizontal fractures that span the outcrop with about 1 to 5 meters spacing and a representative orientation of $(254,26)$. Another set of subvertical fractures also span the outcrop with a representative orientation of $(210,83)$. Sub-horizontal fractures are commonly truncated by vertical fractures, figure 4.2. Fractures that do not span the length of the outcrop exhibit a similar pattern and orientation. The intersection and connectivity of these smaller-scale fractures create lithons locally where the horizontal 
fractures truncate at the vertical fractures. One of the sub-horizontal fractures at the base of the outcrop through the end of section 14.2D contains fractured gouge, figure 4.3. Gouge was not observed within the subvertical fractures, however lithons commonly formed at the intersection between the subvertical and sub-horizonal fractures, figure 4.4 .

Veins locally cut the outcrop. They range $0.5-2 \mathrm{~cm}$ in size, $(202,85)$ and $(43$, $61)$ in orientation, and have a white and/or yellow appearance. Some veins contain breccia-like clasts of host rock, the edges of which match the adjacent clast (Figure 4.5-14.2A).

$\underline{14.2 B}$

Rock types and fracture populations in outcrop 14.2B are similar to those described in 14.A (Figure4.2B). At this outcrop, an isolated mass of pillow basalt is bound on the bottom and west side by fractures. Mineralized veins are a similar color as those in 14.2A and also contain angular clasts; however, adjacent clasts do not have matching edges, figure 4.5-14.2B. Closely-spaced fractures also create lithons, although these fractures varying more in orientation, generally striking NE-SW and dipping northwest. Cataclastic matrix supported veins are locally present with rounded clasts of up to $5 \mathrm{~cm}$, a black fine-grained matrix, and a sharp irregular boundary with the host rock, figure 4.6. A sample of this material was taken for microscale analysis. 


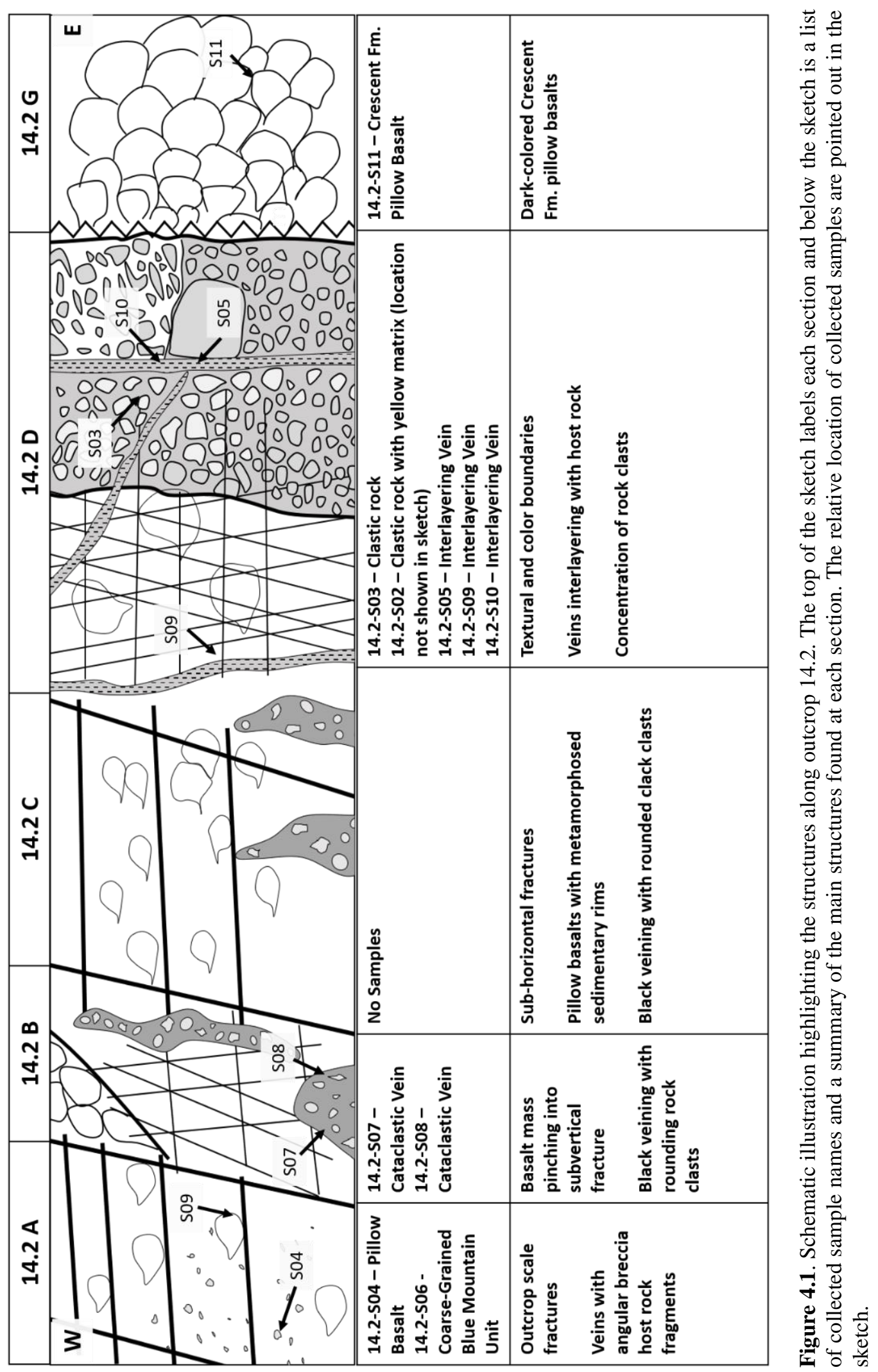




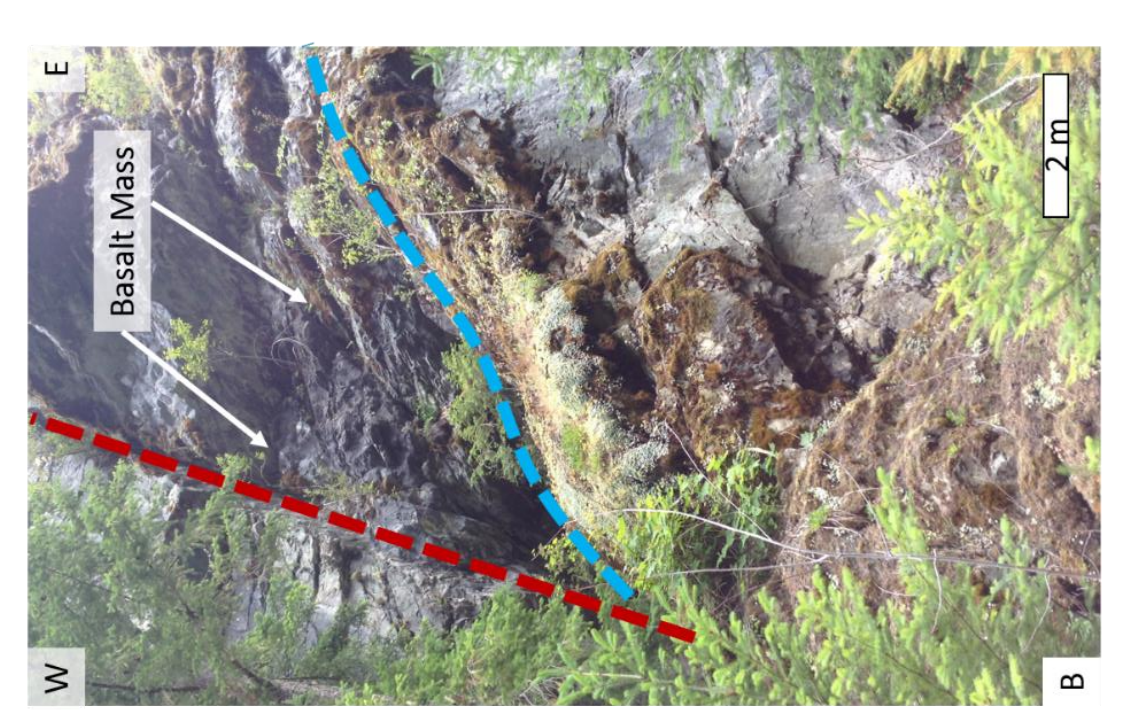

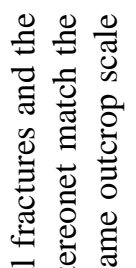

త⿹

気导

产商兽

我 过

言离密

중ㅎㅇ

के

웡응

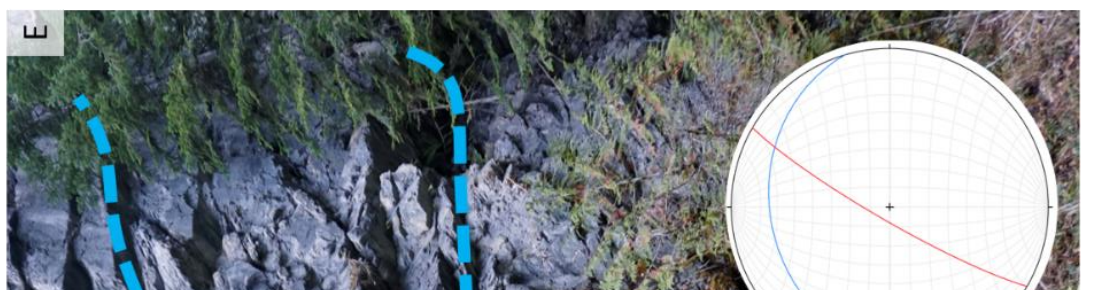

늠 을

边 的

런 츤

兽导高

马्ये

ص 흥 웡

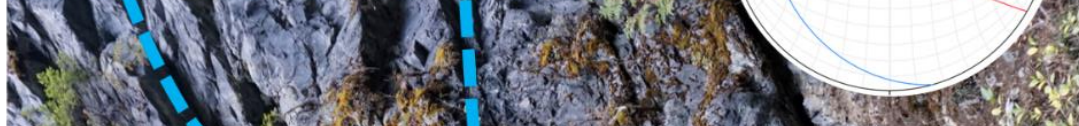

B.

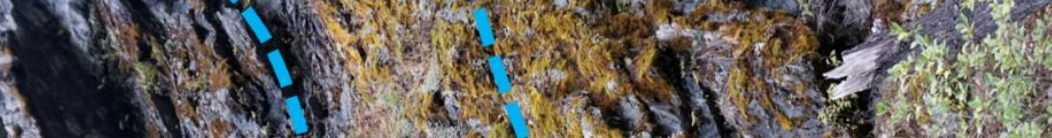

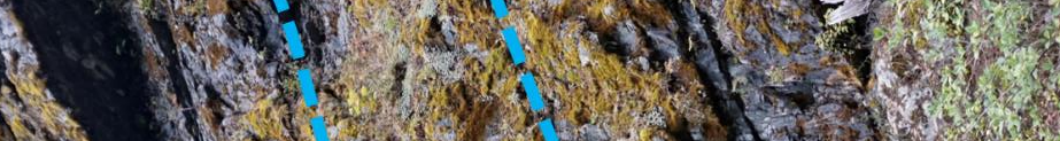

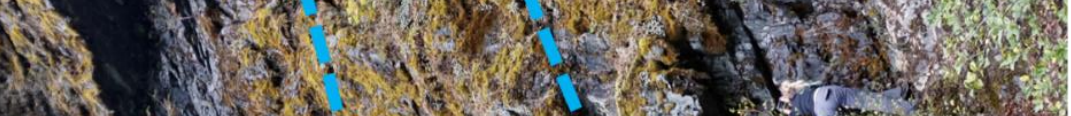

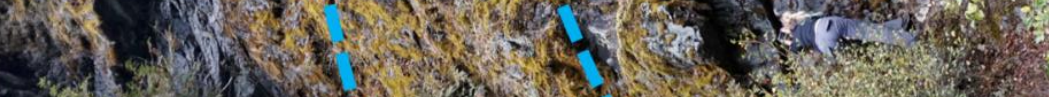

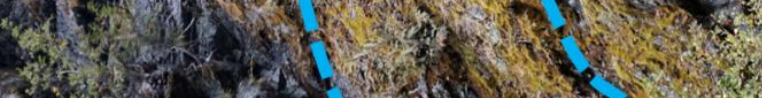

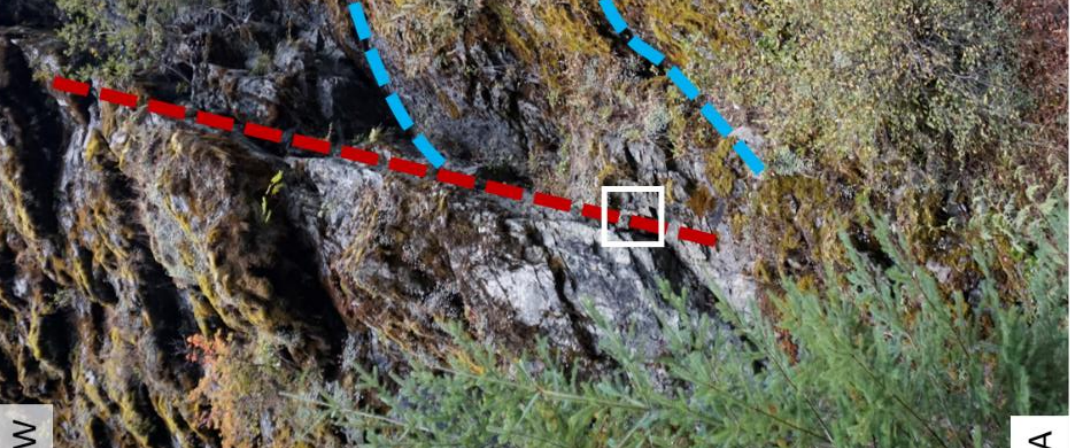

चै

$\varangle \stackrel{0}{0}$

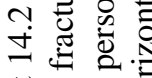

त 00 \&

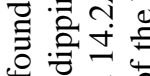

4 क

总恶产

ज्ञ

‡

동 巳

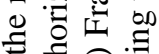

专市

ये के

임 $\frac{0}{0}$

豞艺

㐾总导

ํ.

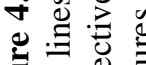

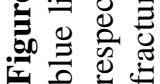




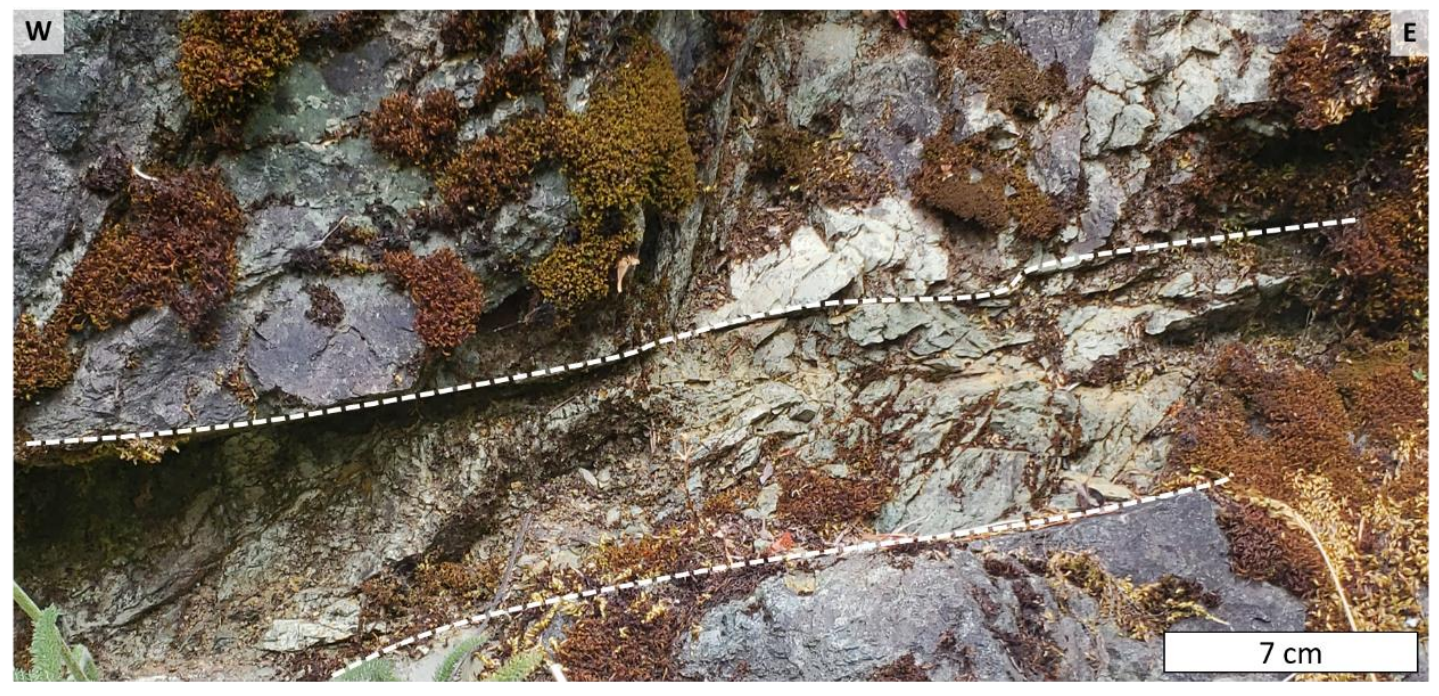

Figure 4.3. Image of fracture gouge for a sub-horizontal fracture at 14.2 A. The upper and lower boundaries (dashed white lines) bound the fractured gouge.

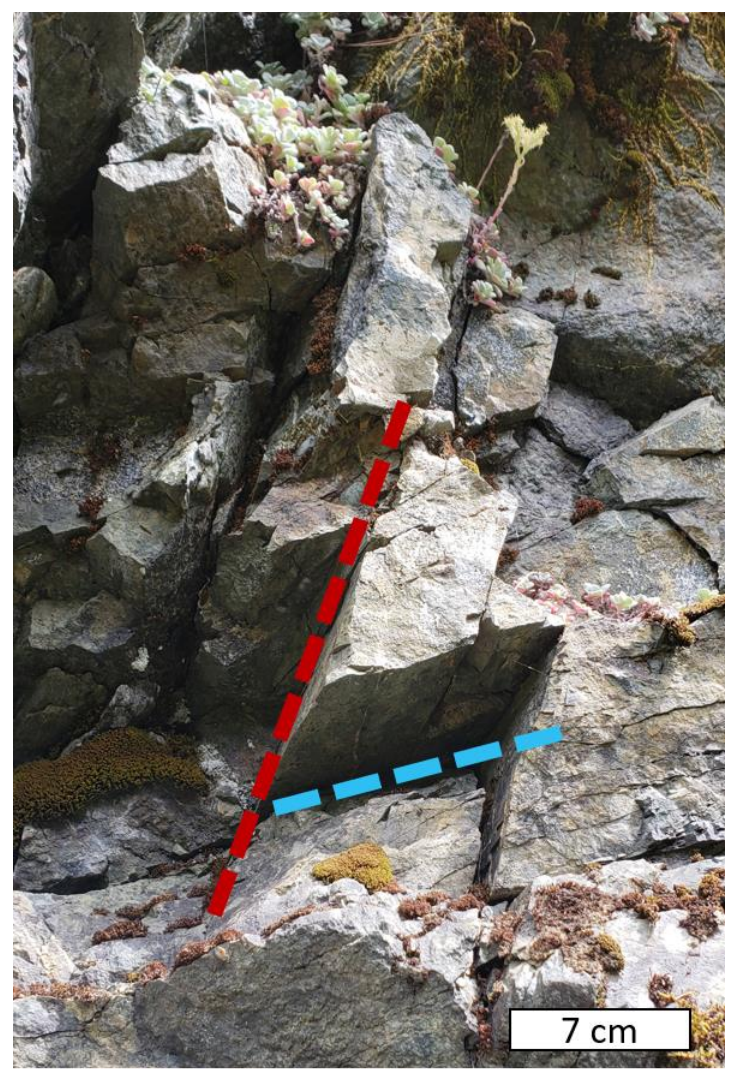

Figure 4.4. Zoomed in image of lithons from the white box in figure 4.2A. Lithons form at the contacts between the subvertical (red dashed line) and sub-horizontal (blue dashed line) fractures. Fractures bounding the lithons are similar orientations of the outcrop scale fractures. 

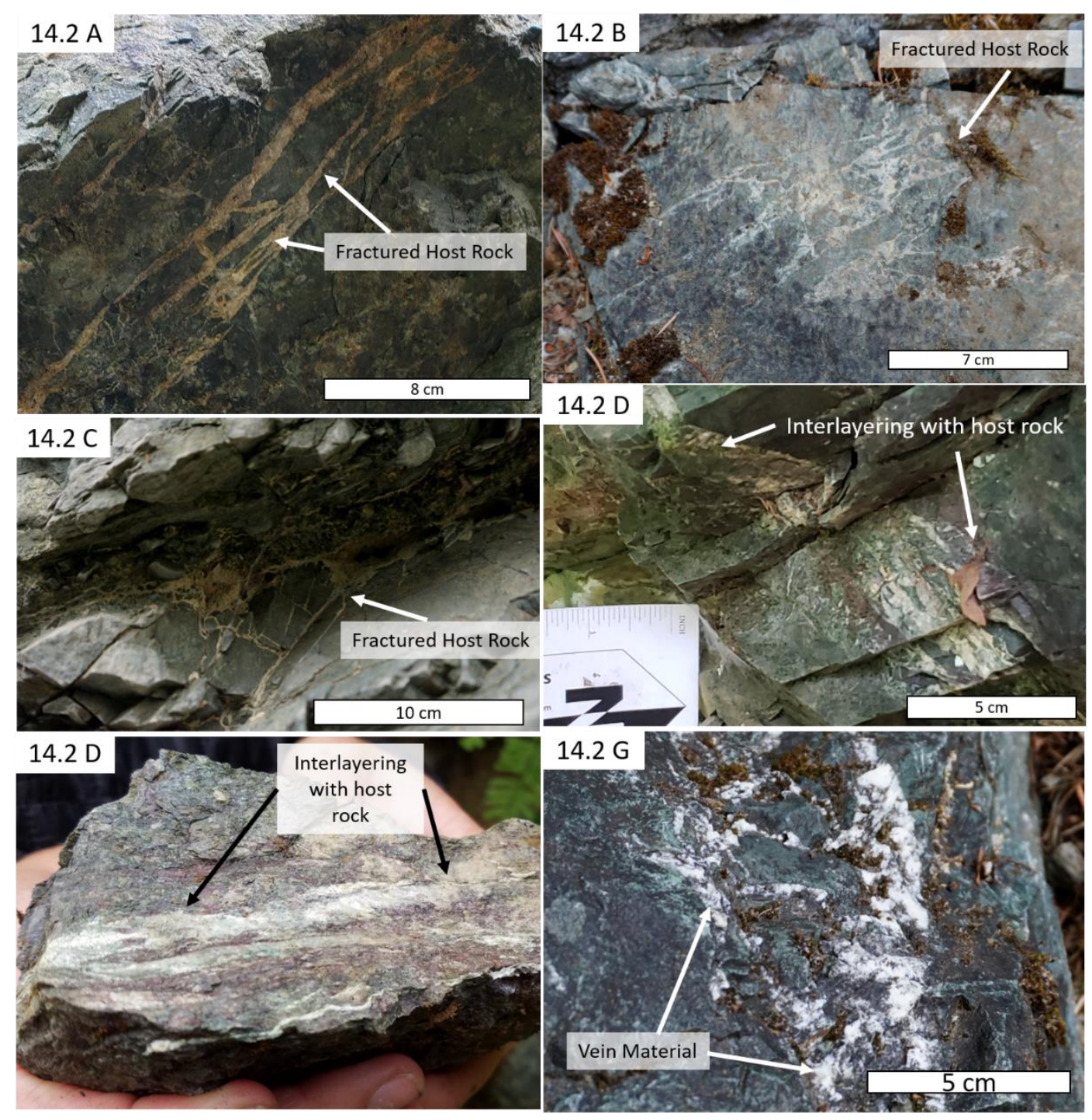

Figure 4.5. Images of veining across outcrop 14.2. Each image is label with their respective outcrop section. 


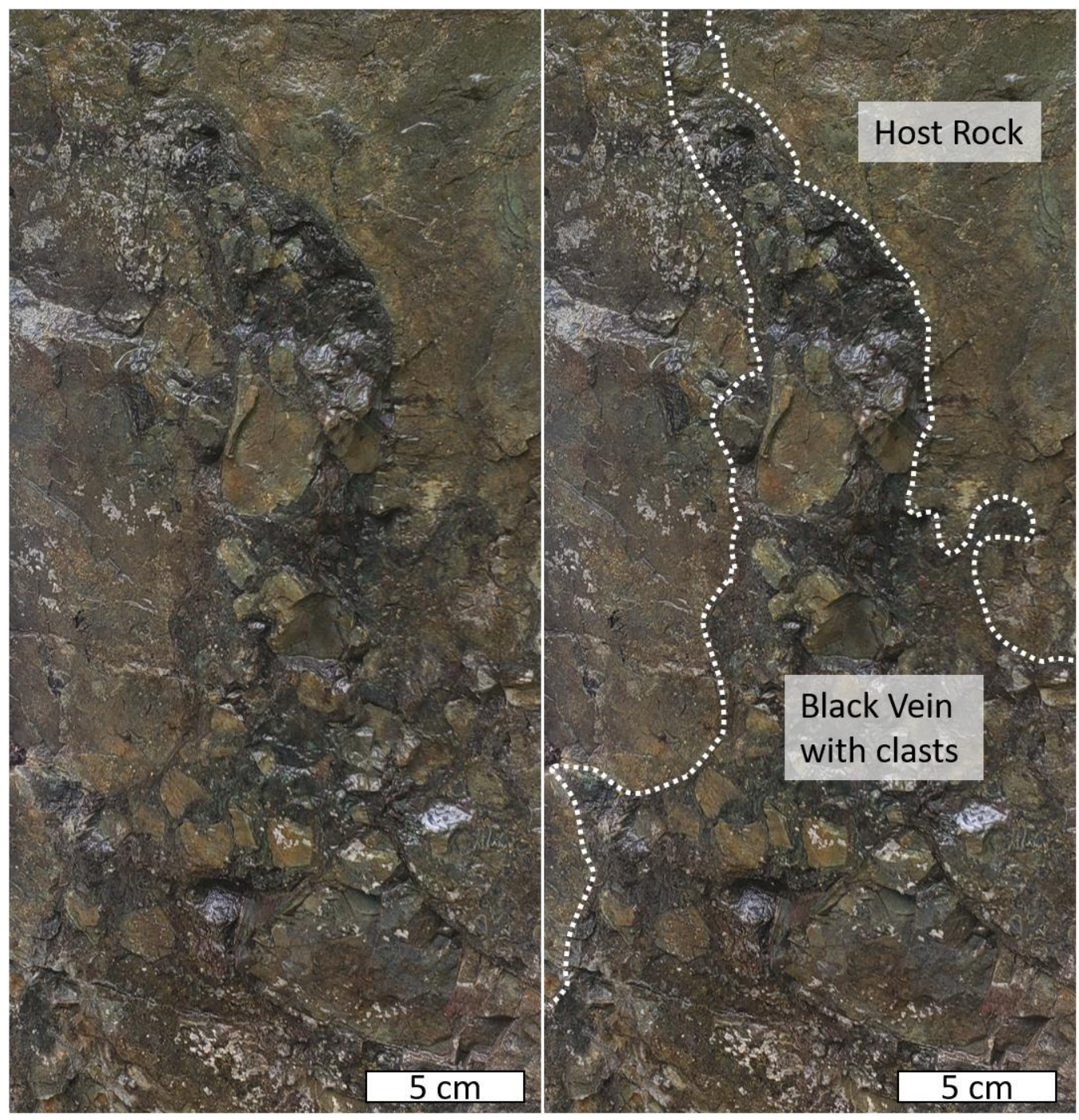

Figure 4.6. Host rock clasts surrounded by black matrix in a vein at 14.2B. Left) Original picture. Right) Annotated picture showing the boundaries between the vein and host rock.

\section{$\underline{14.2 C}$}

14.2C is an outcrop made of pillow basalts that contains similar features to outcrops 14.2A and 14.2B. It has similar sub-horizontal fractures, in size and orientation, black veins containing rounded clasts of host rock (Figure 4.7C), and white or yellow mineralized veins, some containing clasts of the host rock (Figure 5.4- 
14.2C). Pillow basalts are more prominent, and BMU rocks found in 14.2A and 14.2B are not observed in this outcrop. Pillow basalts are best identified by metamorphosed interstitial sediment rims (Figure 4.7A). A sub-horizontal fault structure at the base of this section is similar in orientation $(255,23)$ to the sub-horizontal fractures, is red and green at the edges, and contains matrix supported gouge (Figure 4.7B).

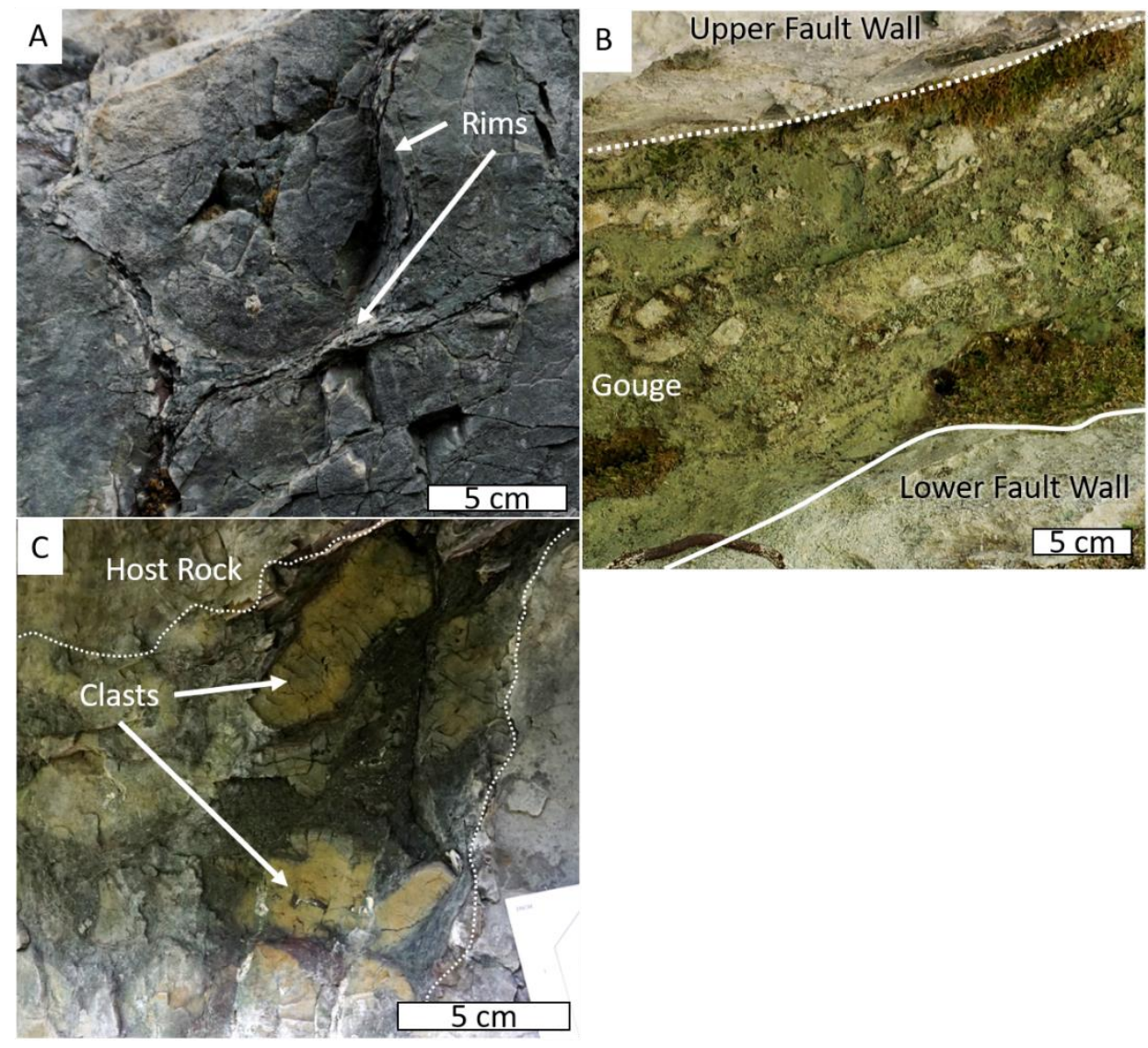

Figure 4.7. Structures found at site 14.2 C. A) Pillow basalts and metamorphosed rims. B) Gouge within an outcrop-scale horizontal fault structure. C) Clasts within a black vein. 


\section{$14.2 D$}

On the western end of outcrop $14.2 \mathrm{D}$ is fractured host rock and on the eastern end the outcrop is composed of rock clasts and gouge. Two apparent fracture populations are apparent on the western end of this subsection and are generally oriented at $(195,25)$ and $(193,71)$, and intersect and form lithons (Figure 4.8). On the eastern end of the outcrop, the rock is made up of clasts within either a black or yellow fine-grained matrix. The clasts range from angular to rounded in shape and millimeters to decimeters in size (Figure 4.9A). Clast compositions at outcrop scale appear to be the surrounding host rock (Figure 4.9B), and both fractures and veins cross-cut the clastic material (Figure 4.10B).

Veins are similar to those seen in outcrops $14.2 \mathrm{~A}$ to $\mathrm{C}$ and a new vein type is observed. Toward the west end, a vein that contains clasts of host rock also appears to interlayer with the host rock, (Figure 4.10A). Within the area that has the rock clasts to the east, the vein cuts and also interlayers with the clastic host rock, although it is redder in appearance and more difficult to discern from the complexity of the host rock, figure $4.10 \mathrm{~B}$ and $\mathrm{C}$.

The transition into and through the clastic rock is marked by changes in the appearance, or texture of the outcrop and matrix color, which is apparent as distinct boundaries. The color boundaries occur where there is a difference between zones of black and yellow matrix, figure 4.9A and C. There are three notable boundaries from west to east at locality $14.2 \mathrm{D}$. First, is a change from grey rock with clearly defined pillows to a matrix supported clastic rock that is red and green, figure 4.11A and B. 


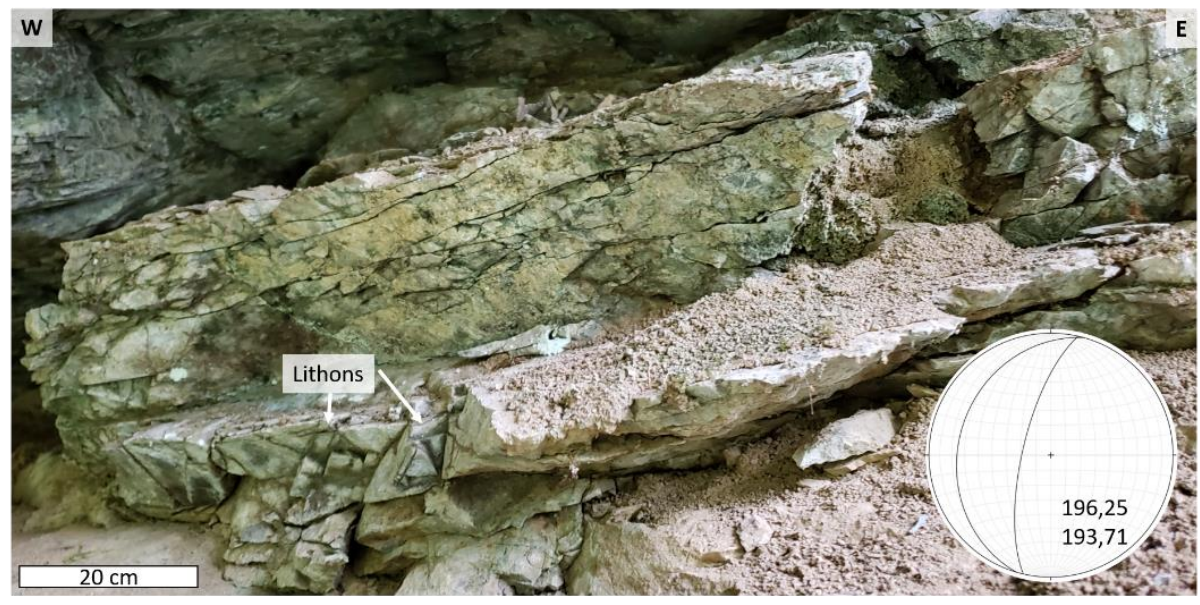

Figure 4.8. Image from the west end of locality 14.2 D, where cross-cutting fractures make lithons. The lower-hemisphere equal area stereonet shows the common representative fracture orientations in this outcrop section.

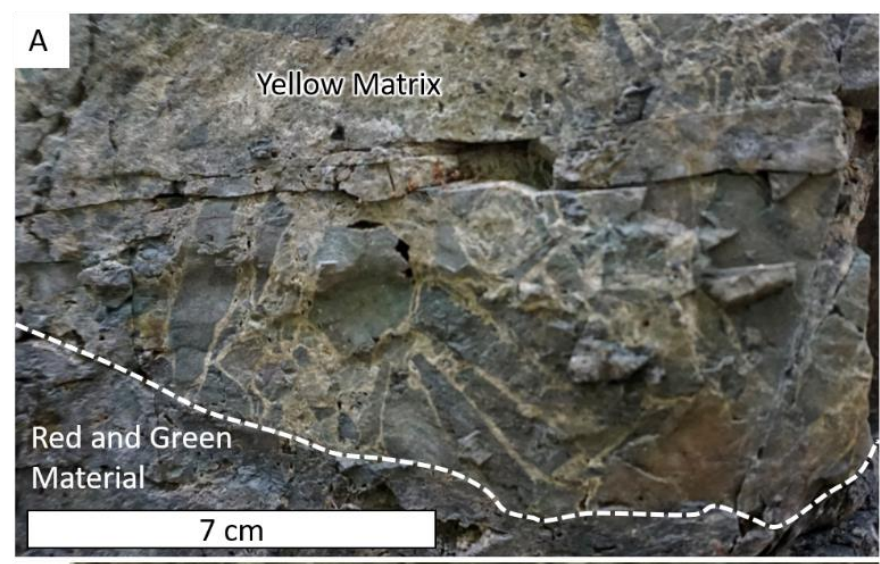

Figure 4.9. Images of the different clast sizes and range of matrix colors at locality $14.2 \mathrm{D}$. A) Clasts within a yellow matrix, the boundary with the darker red and green material is shown by the white dashed line. B) Rounded clasts within a darker matrix.

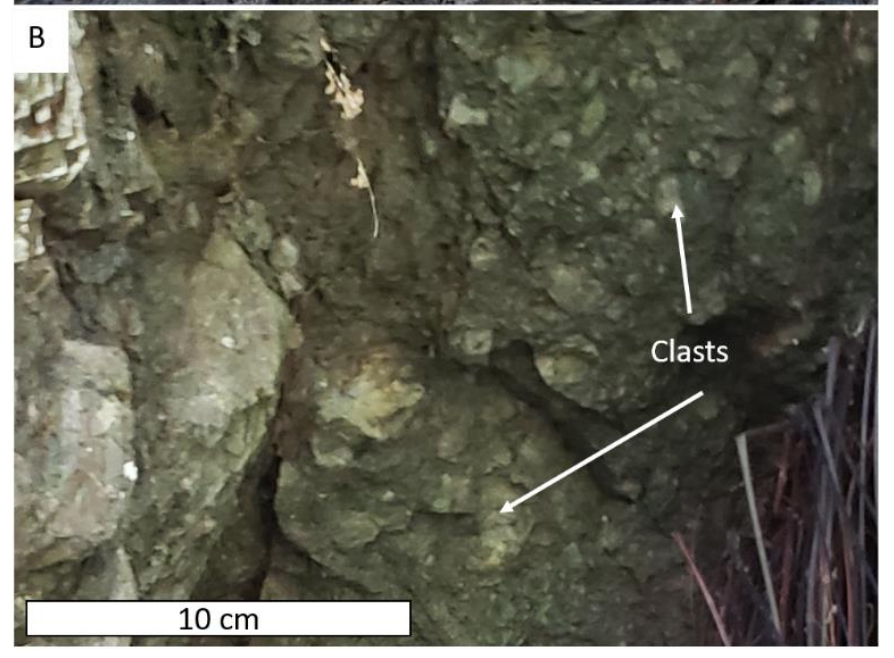




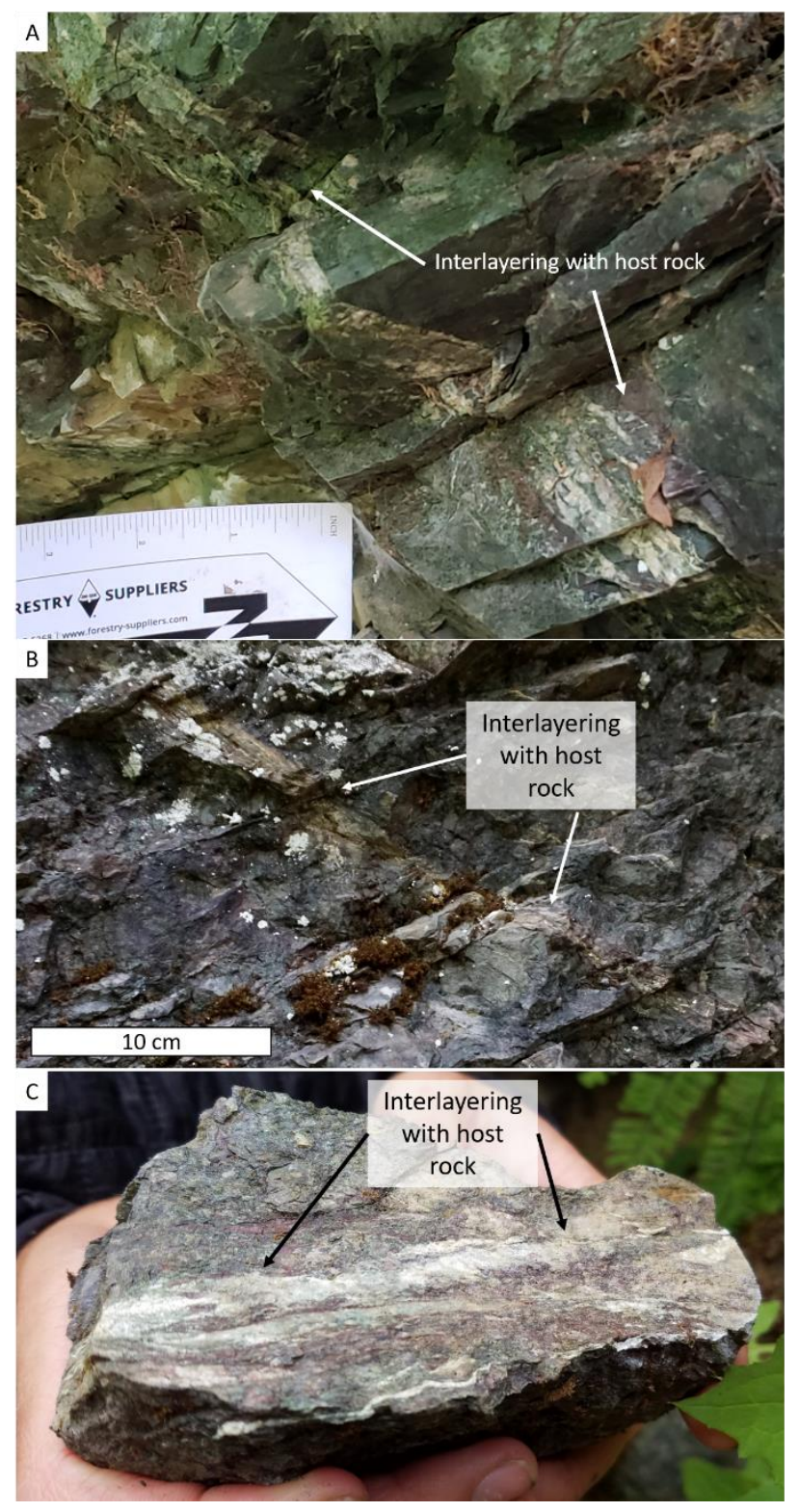

Figure 4.10. Different veins found at $14.2 \mathrm{D}$, all interlayering with the host rock. A) Vein from the west of the section. The vein alternates between quartz and host rock material. B) Vein interlayering with the red and green host rock material. C) Sample taken from a similar vein as B. A closer look at the interlayering between vein and host rock material, in hand sample.

This texture continues eastward approximately $2 \mathrm{~m}$ until the next boundary where the outcrop changes to grey and fractured rock. Finally, about $1 \mathrm{~m}$ east of the grey fractured rock, a boundary marks where the rock returns to a red and green material. The rock type exposed at the eastern margin of $14.2 \mathrm{D}$ and sections $\mathrm{E}$ and $\mathrm{F}$ is unclear due to moss-covered rock. 


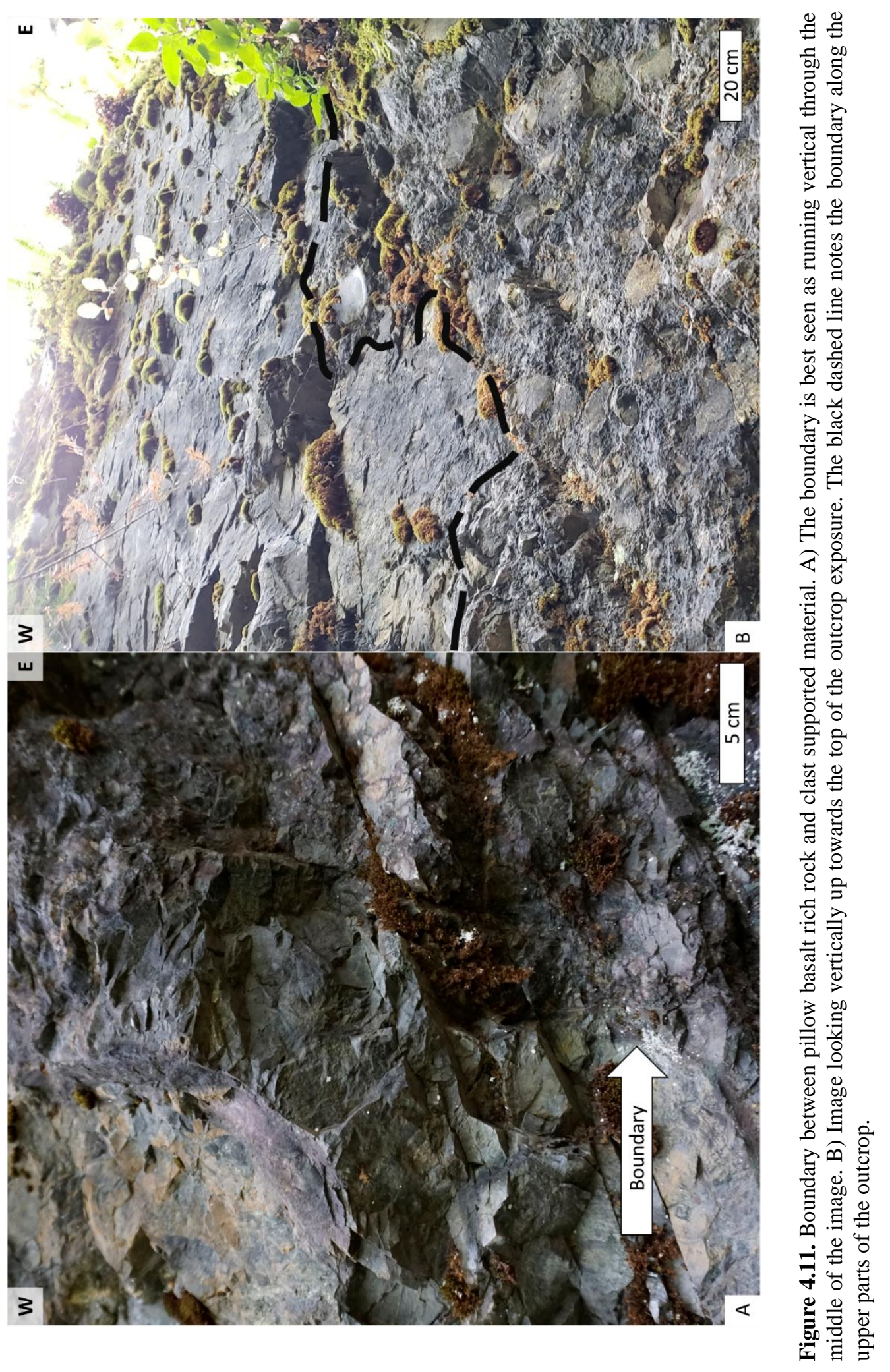


The majority of structures found in the preceding sections cease in $14.2 \mathrm{G}$.

There are no longer cataclastic veins containing clasts of host rock, a mixture of rock types, outcrop scale subvertical and sub-horizontal fracturing, or lithons. The outcrop is comprised of dark-colored pillow basalts, figure 4.12. There are some fractures that span the entire outcrop, however many of the fractures at this outcrop are en echelon in nature where they are not continuous and connect through the entire outcrop but instead are locally contained within pillows. There is some veining, mainly yellow and white, and some veins containing host rock fragments, figure 4.5-14.2G.

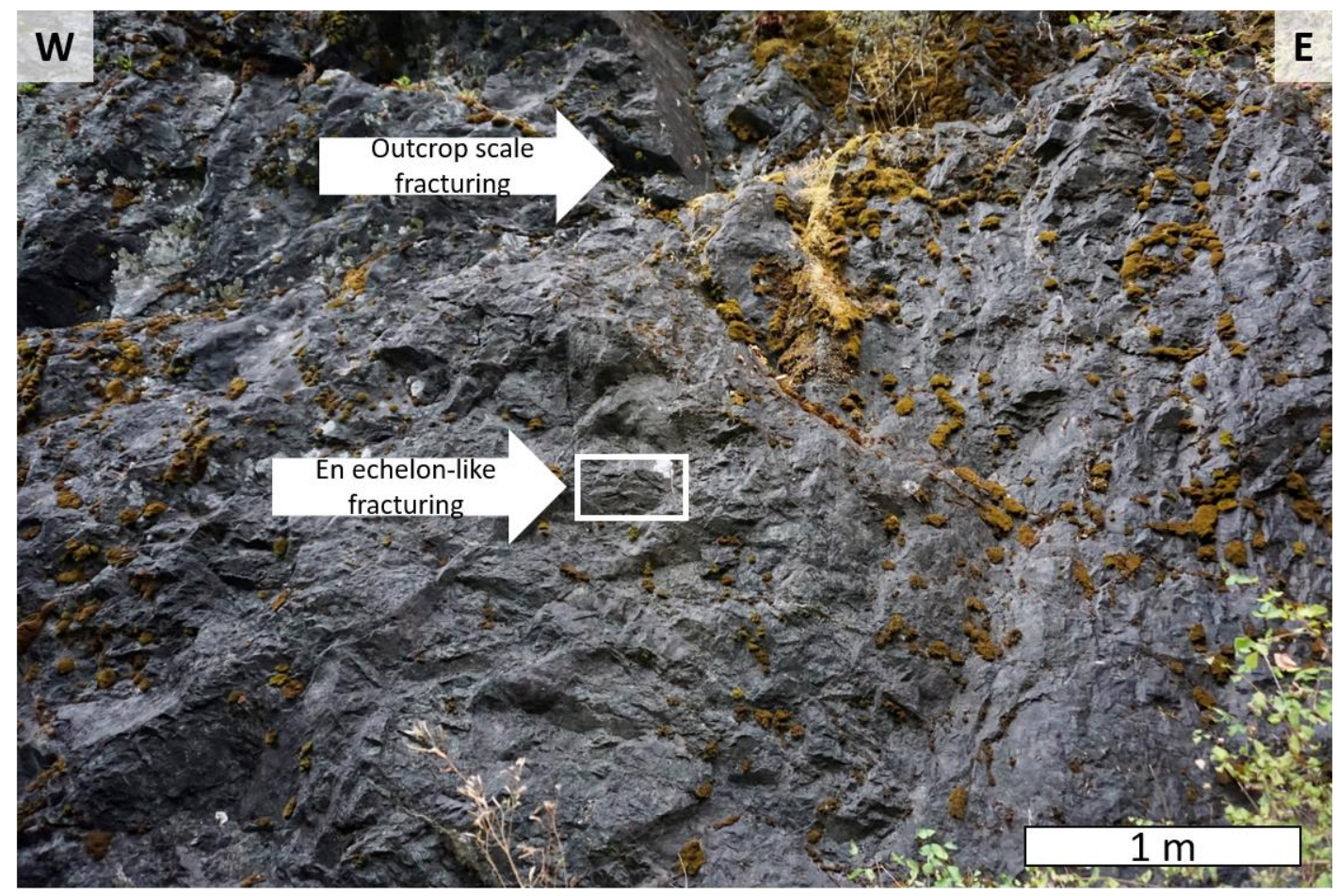

Figure 4.12. The pillow basalts of outcrop $14.2 \mathrm{G}$. The outcrop is comprised of dark-colored pillow basalts with some fractures that span the entire outcrop and smaller en echelon-like fractures. 


\subsubsection{Orientation Data}

\section{Bedding Orientation}

Bedding orientations were taken from the tops of basalt pillows. There are two general orientations, trending NNE-SSW and WSW-ENE, both steeply dipping, figure 4.13.

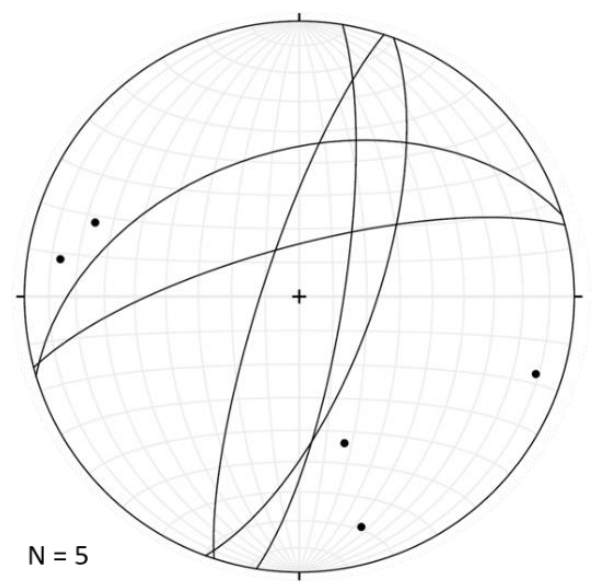

Figure 4.13. Equal area lower hemisphere stereonet of the bedding planes and poles at outcrop 14.2.

\section{Fracture Orientations}

Fracture data was divided into respective outcrop subsections. Representative fracture orientations, their relative acute angles, and calculated Sigma-1 orientations are summarized in Table 4.1 and shown in stereographic figures in the appendix (Figures $\mathrm{C} 1$ and $\mathrm{C} 2$ ). Section $14.2 \mathrm{~B}$ has a small sample size relative to the other sections and is grouped with section 14.2C. Representative fracture planes for sections A-D have similar fracture and Sigma-1 orientations whereas $14.2 \mathrm{G}$ has different orientations. The predicted Sigma-1 for $14.2 \mathrm{G}$ plots in the NE quadrant compared to 
the other sections with plot in the NW quadrant. If all the fracture data for the entire outcrop are considered together, the overall representative fracture planes and predicted Sigma-1 are at similar orientations as 14.2A-D, figure 4.14.

Table 4.1. Summary of the fracture representation planes, the acute angle between them, and the calculated Sigma-1 orientation for outcrop 14.2.

\begin{tabular}{|l|l|l|r|l|}
\hline Outcrop Name & Rep Plane 1 & Rep Plane 2 & Acute Angle & Sigma-1 \\
\hline 14.2 A & 254,26 & 210,83 & 65 & $276 \rightarrow 47$ \\
\hline 14.2 B/C & 225,23 & 213,62 & 40 & $295 \rightarrow 41$ \\
\hline 14.2 D & 196,25 & 193,71 & 46 & $280 \rightarrow 48$ \\
\hline 14.2 G & 208,18 & 316,24 & 35 & $076 \rightarrow 05$ \\
\hline 14.2 All Data & 212,85 & 198,25 & 63 & $311 \rightarrow 53$ \\
\hline
\end{tabular}
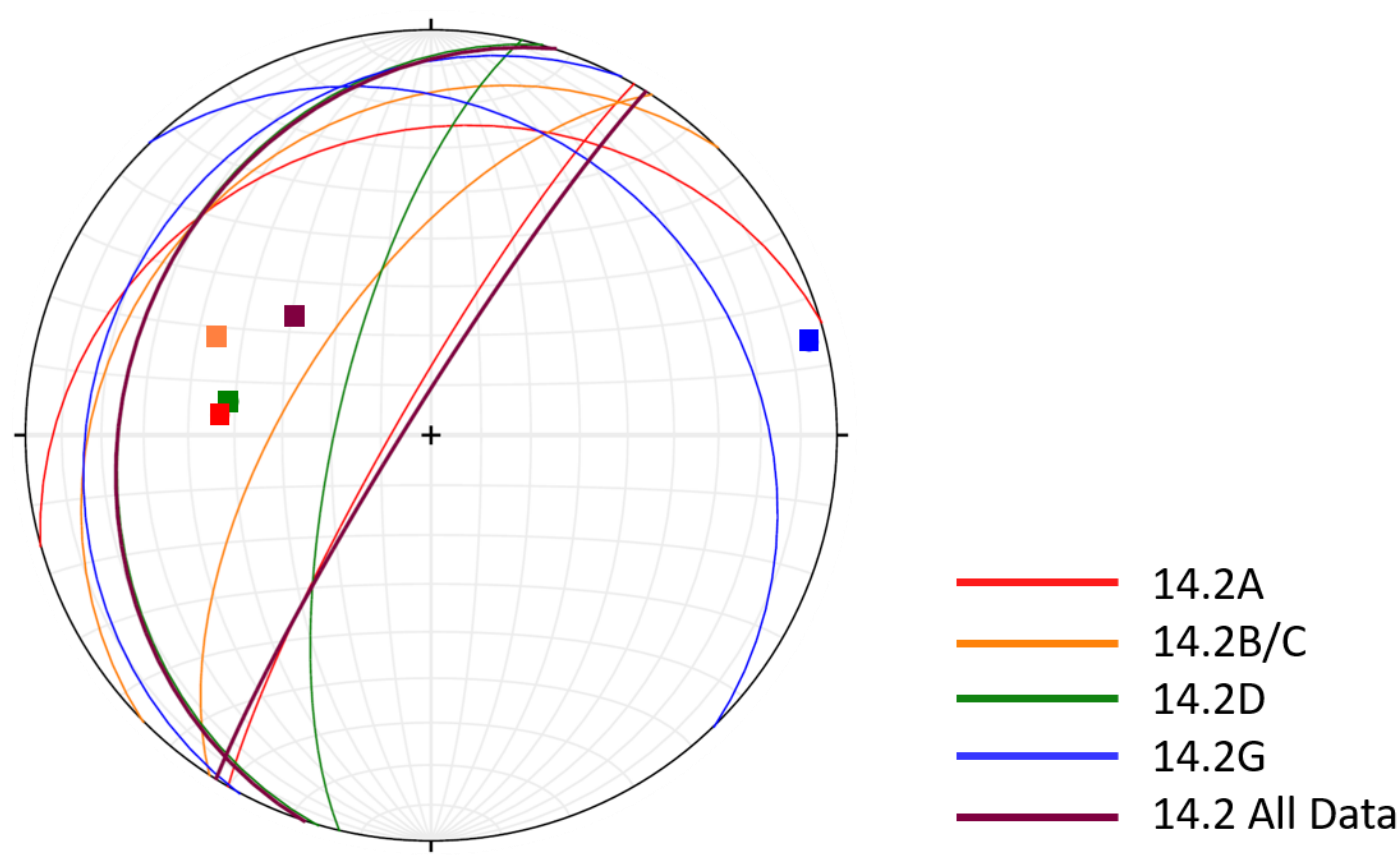

Figure 4.14. Equal area lower hemisphere stereonet of the representative fracture planes from each site in the 14.2 outcrop. The solid lines are the fracture planes and the dots are the predicted Sigma-1 orientations. Each colored plane has Sigma-1 orientation of the same color. 


\section{Vein Orientations}

Figure 4.15 shows the vein planes and poles on stereonets for the variety of veins observed throughout 14.2. The interlayering veins at $14.2 \mathrm{D}$ are oriented $(27,27)$, $(127,16)$, and $(208,87)$. Most of the planes vary in dip but primarily strike in a northerly direction. This is also evident in the pattern of poles, where they fan across the plot rather than cluster.
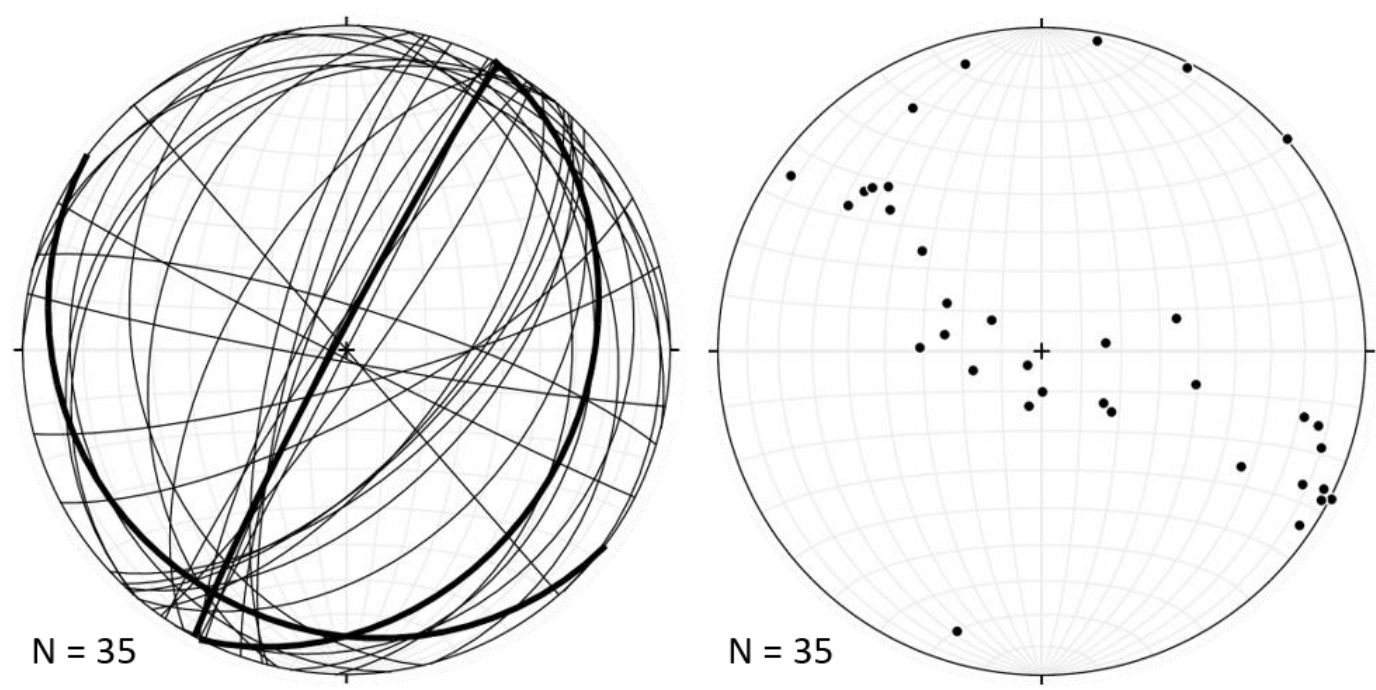

Figure 4.15. Equal area lower hemisphere stereonet of the vein planes (left) and poles (right) for outcrop 14.2. The orientations of interlayering veins are the thicker lines.

\subsubsection{Microscale Data and Observations}

Host rock, vein, and fault material samples were collected from outcrop 14.2.

The following minerals were present in the rock samples: amphibole, calcite, chlorite*, epidote*, feldspar/plagioclase*, hornblende, iron oxide, prehnite*, pumpellyite*, pyrite, quartz*, and titanite. The following minerals were present in the vein samples: chlorite, quartz, prehnite, epidote, pumpellyite, and calcite. (Note: 
Asterisks indicate minerals commonly used to identify metamorphic facies). These samples and their associated minerals are discussed in more detail below.

$\underline{14.2 \mathrm{~A}}$

A sample of a pillow basalt and the coarse-grained rock with clasts were taken for microscale analysis. The basalt sample contained plagioclase phenocrysts in a groundmass of interlocking hornblende, feldspar, pumpellyite, and titanite grains. The clasts of the coarser-grain rock includes (a) plagioclase phenocrysts, (b) pockets of altered vein-like material with pumpellyite, plagioclase, and chlorite, and (c) rounded to ameboid-shaped grains that morph around neighboring grains and contain chlorite cores. At the nanoscale, the grains are compositionally zoned with an Al-rich core and $\mathrm{Fe} / \mathrm{Mg}$-rich rims, figure 4.16A. Throughout the sample are titanite crystals, varying in shape. At the edges of the morphed grains, titanite is elongated, whereas the cores have a concentration of circular titanite.

\section{$14.2 \mathrm{~B}$}

The sample from 14.2B was taken from the black vein material and contained rounded to angular clasts of varying sizes, figure 4.17. The clasts in this sample are fractured and mineralized fragments of basalt and BMU host rock that contain amphibole, feldspar, and quartz. The matrix contains quartz, titanite, pumpellyite, chlorite, feldspar, iron oxides, and epidote. Veins in this sample are made of calcite, prehnite, quartz, and pumpellyite. The edge of clasts are distinguished by an abrupt change in matrix grain size, where there is a fine-grained matrix with angular clasts 
next to coarser-grained, interlocking minerals of the host rock. The edges of some

clasts have a less distinct boundary with the matrix, with finer grained clasts that

decrease in size moving outward from the clast center, figure 4.18. Parts of the matrix

have distinct boundaries between other matrix material. Compositional and grain-size

differences highlight these boundaries. For example, there is a compositional

difference between the iron oxides and neighboring compositions, figure 4.19.

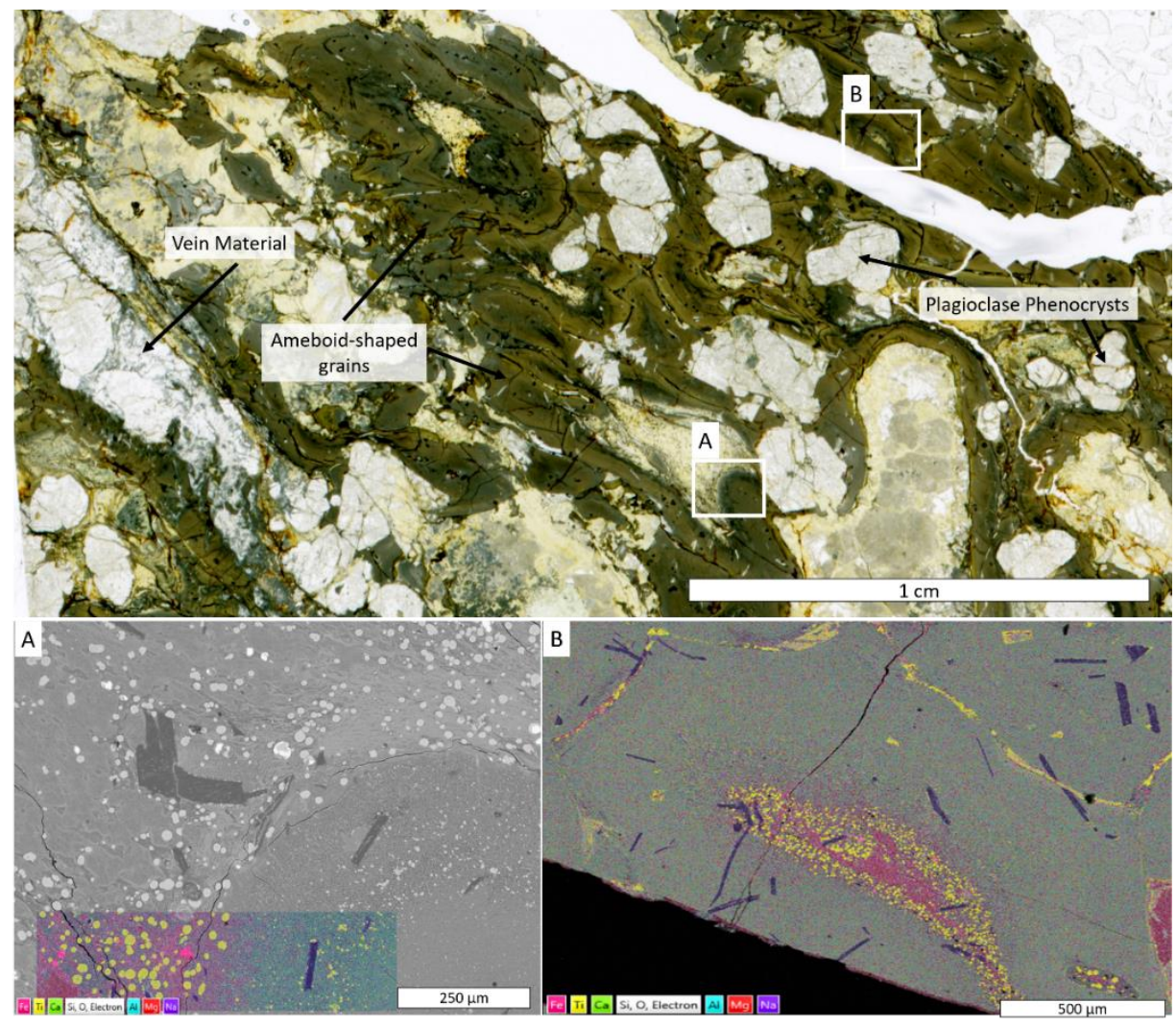

Figure 4.16. Micrographs of sample 14.2-S06A. Top is an annotated plane polarized thin section image of the sample. Vein material, grain shape, and phenocrysts are labeled. The location of the bottom backscattered electron and energy dispersive elemental micrographs are labeled respectively. A) Backscattered electron micrograph of a grain edge composition zoning. The center and mantle are Al-rich, and the rim is $\mathrm{Fe}$ and $\mathrm{Mg}$-rich. The yellow features are titanite grains, the dark purple features are feldspar grains. B) Energy dispersive elemental map of an ameboid-shaped grain. The pink to red areas are chlorite. This grain does not have the same degree of composition zoning as the grain at A. The yellow features are titanite grains, which are circular within the grain and elongated along the perimeter of the grain. 


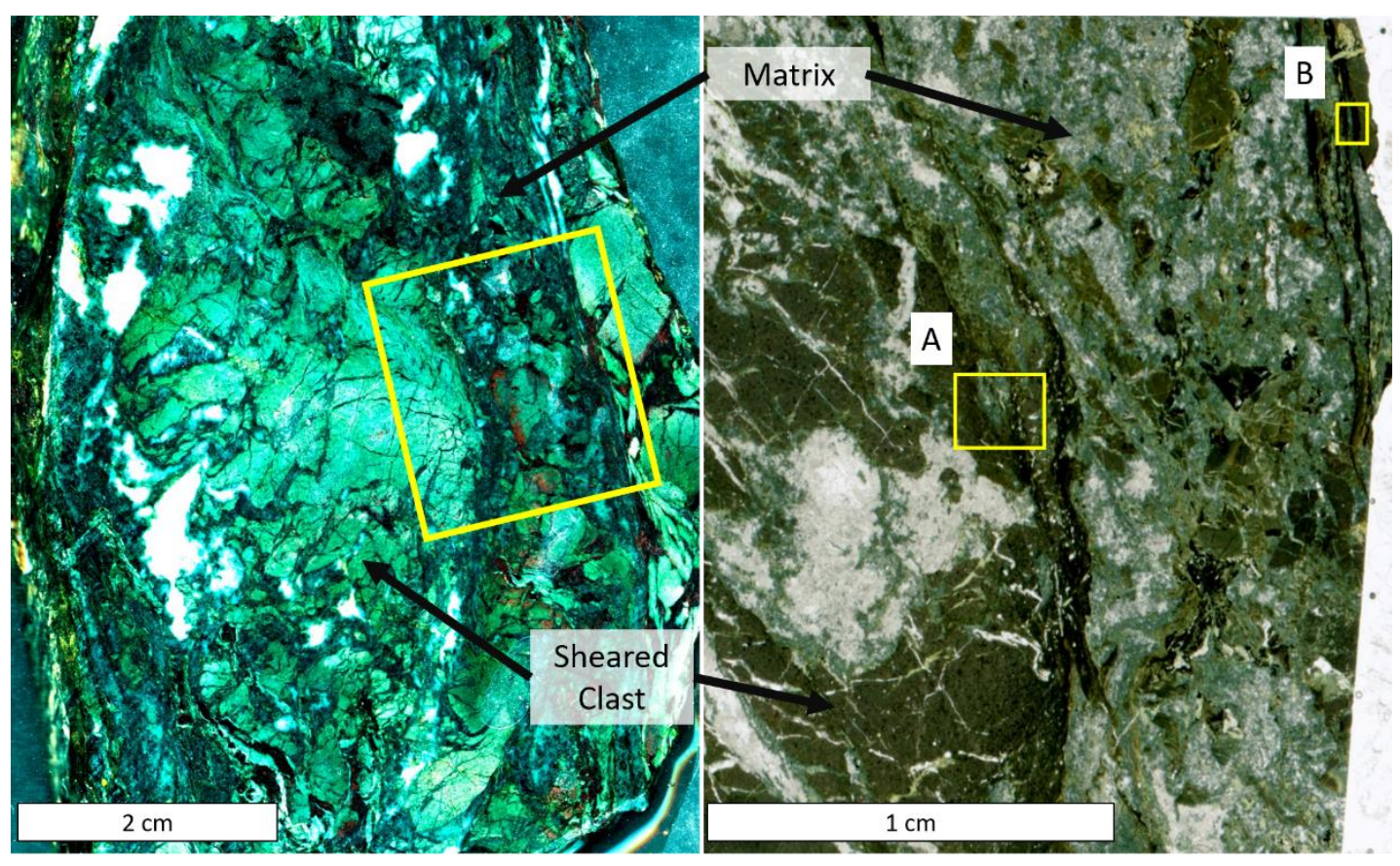

Figure 4.17. Slab scan (left) and plane polarized thin section (right) images of sample DOS14.2-207A. Left) The yellow box on the slab scan notes the location of the thin section image. Right) Yellow boxes in the thin section image show the locations of the backscattered electron images in figures 4.18 (A) and 4.19 (B). 


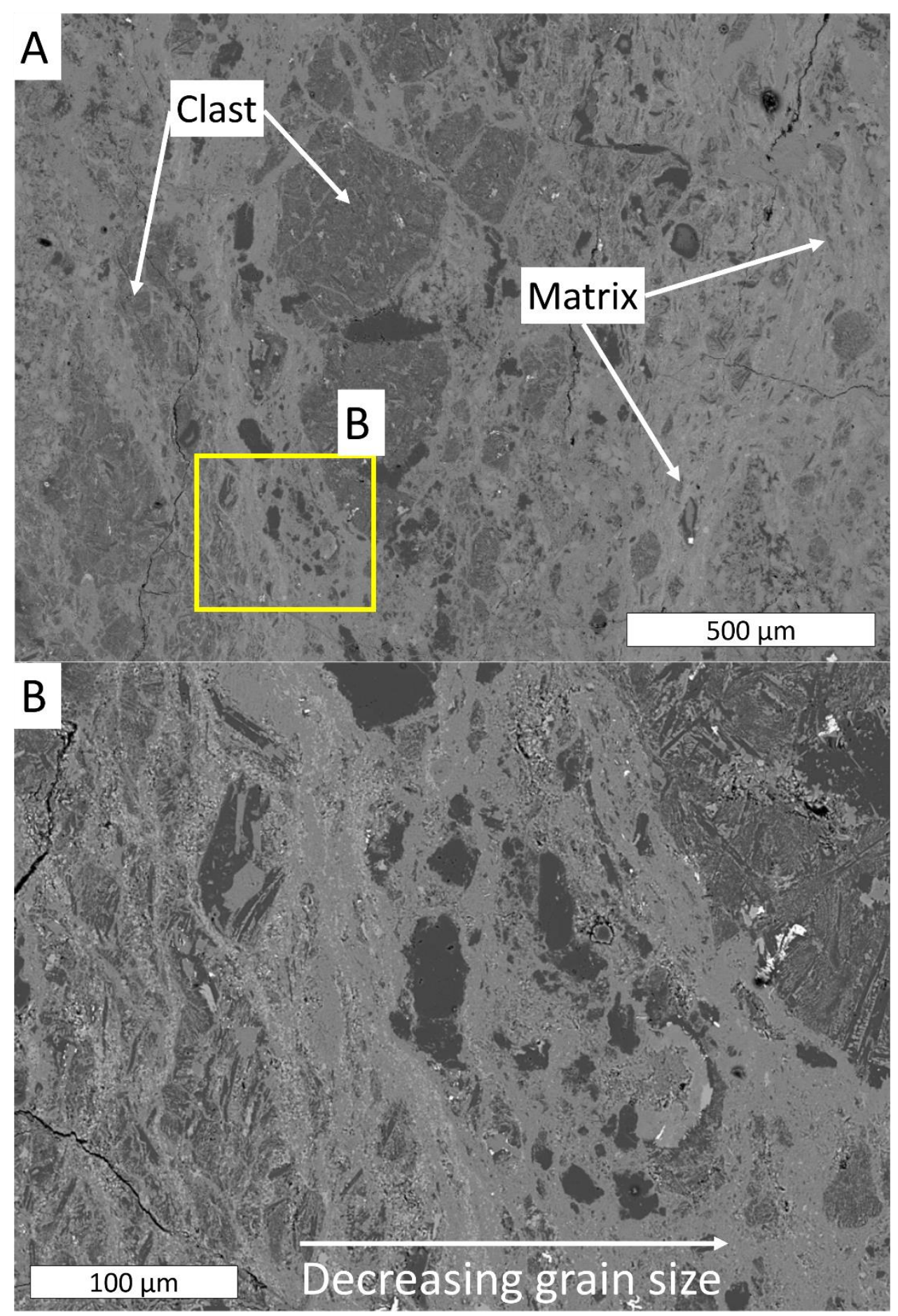

Figure 4.18. Backscattered electron images of the edge of a clast in sample DOS14.2-S07A. A) View of the clast edge highlighted in figure 4.17. B) Finer scale image of the yellow box in A. There is a gradational change in grain sizes moving to the right, away from the clast edge. 

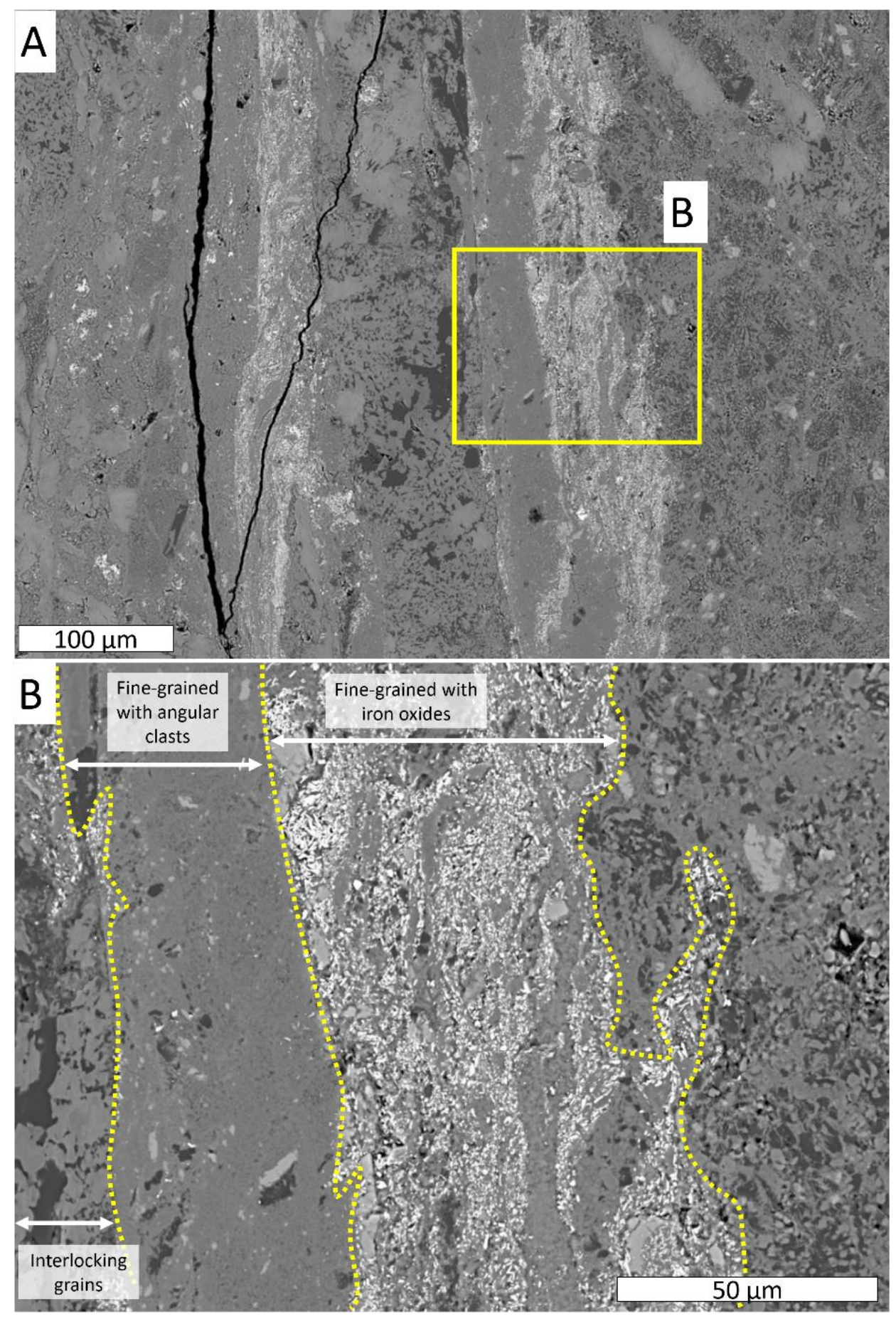

Figure 4.19. Backscattered electron micrograph of distinctly different zones in the matrix of sample DOS14.2-S07A. A) Image of the boundaries between different materials within the matrix. B) Finer scale image of the yellow box in A. Yellow lines outline distinct boundaries between different materials in the matrix; from left to right: interlocking grains, fine-grained with angular clasts, and fine-grained with iron oxides. 
Multiple samples taken throughout the entire outcrop subsection focused on veins and clastic rock. These samples include: a vein interlayered with the grey host rock (e.g., Figure 4.10A), the clastic rock with yellow matrix material (e.g., upper right, Figure 4.9A), the green and red clastic rock (e.g., lower left, Figure 4.9B), and a vein interlayered with the green and red host rock (e.g., Figure 4.10B and C). The host rock and clasts are made of quartz, prehnite, epidote, pumpellyite, titanite, and chlorite. Veins consist of quartz and prehnite and matrix contains the minerals pumpellyite, titanite, chlorite, quartz, iron oxide, prehnite, and epidote.

One sample was collected from a vein that is interlayered with the grey host rock, figure 4.10A. At the microscale, there are subparallel planes of vein material, host rock, and cataclastic material, figure 4.20. The vein material is quartz, pumpellyite, and epidote, the host rock material is iron oxides, pumpellyite, amphibole, quartz, titanite, and epidote, and the cataclastic material includes clasts of host rock and matrix of quartz, pumpellyite, and titanite.

A sample was taken from the clastic rock with yellow-colored matrix material. This sample spanned one of the contacts between the yellow-colored matrix material and the red and green clastic rock (e.g., Figure 4.9A). Where there is yellow-colored matrix, the clasts are rounded and made up of host rock and cataclasite (i.e., very-finegrained comminuted material distinguishable at the nanoscale), figure 4.21A and C. The clasts are made of quartz, prehnite, epidote, pumpellyite, titanite, and chlorite in a matrix of pumpellyite, titanite, chlorite, quartz, iron oxide, prehnite, and epidote. At 
the contact between the yellow matrix material and green/red rock, there is a chaotic texture and the clasts and matrix become less distinct. Pockets of quartz and epidote vein material occur through this sample (i.e., shown as white patches in the thin section image; Figure 4.21A and B).

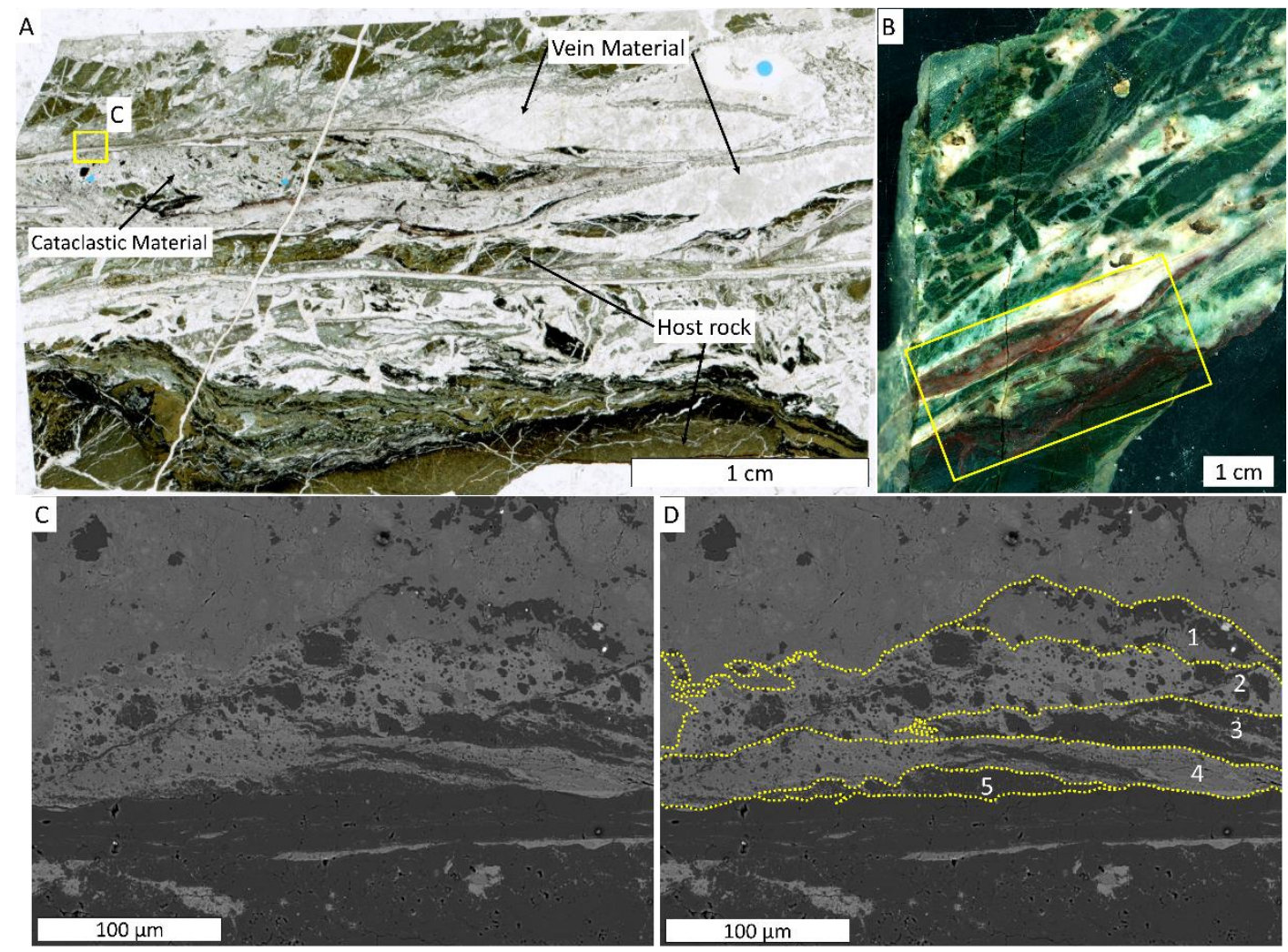

Figure 4.20. Plane polarized thin section, slab scan, and backscattered electron micrograph images of sample DOS14.2-S09B. This sample interlayers with the host rock and has pockets of vein and cataclastic material. A) Thin section image. Yellow box shows location of backscattered electron image in C. B) Slab scan of rock sample. Yellow box outlines the location of the thin section image. C) Backscattered electron micrograph of a plane with cataclastic material wedged in the upper part of the rock. D) Outline of different layers of cataclastic material wedged along a quartz plane. 

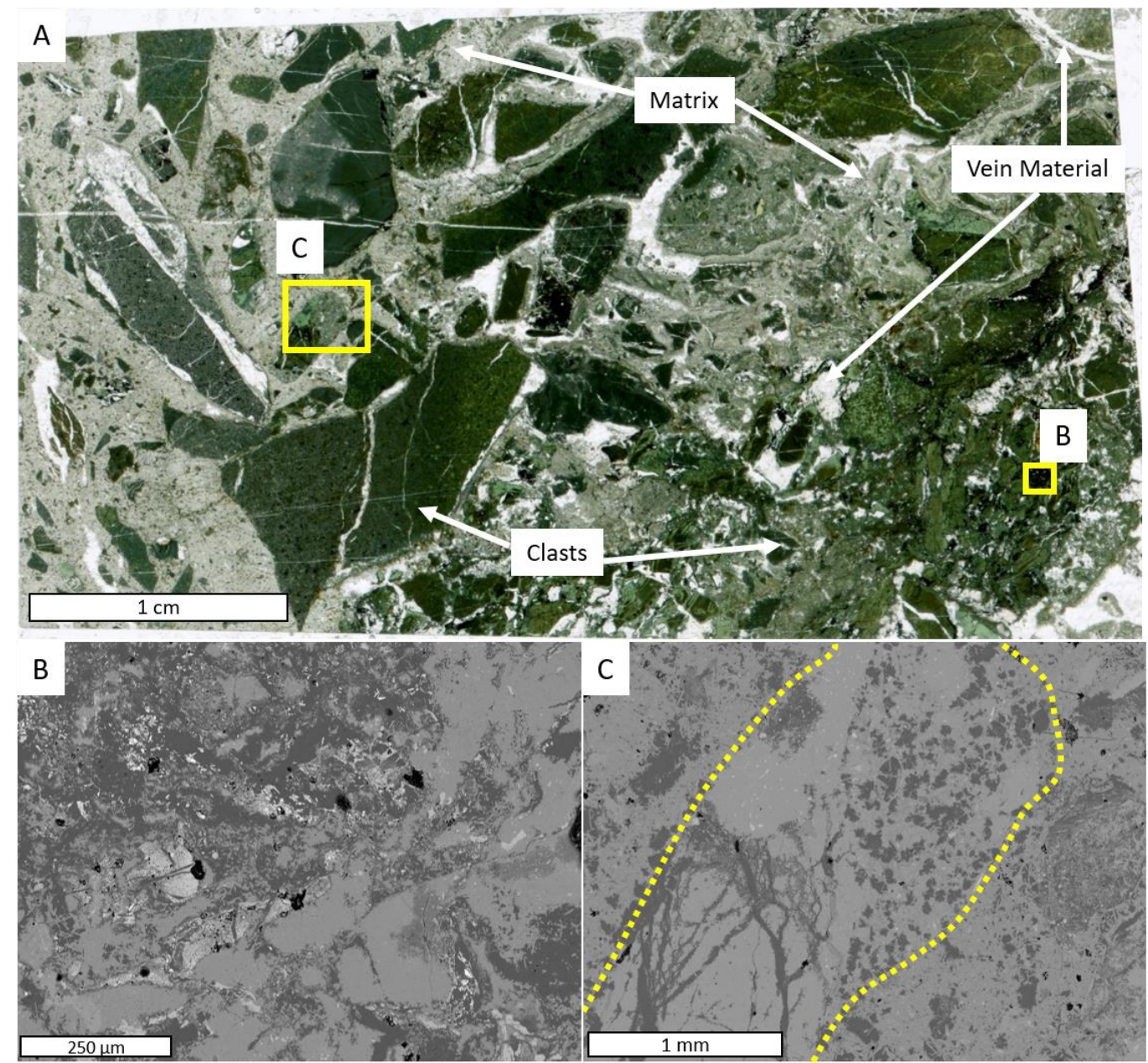

Figure 4.21. Plane polarized and backscattered electron micrograph images of a sample DOS14.2S02B. A) Thin section showing the variety of clast sizes and shapes within and very fine-grained matrix (left side) and the gradual change in the rock as it gets closer to the contact between the pale matrix and red and green rock (right side). Locations of $\mathrm{B}$ and $\mathrm{C}$ backscattered electron images are labeled. B) Micrograph showing the more chaotic texture and shape of clasts and less fine-grained material. C) Micrograph outlining one of the clasts in the yellow-pale matrix. This clast contains cataclastic material in contact with other clasts from the parent rock.

The sample taken from the red and green rock contains a mix of material, including the glassy grains similar to those found in $14.2 \mathrm{~A}$, figure 4.22 . Within the grains are the same mineral textures and circular titanite grains, though this sample lacks titanite grains at its edges. Other parts of the sample have material filling in crevasses between grains, figure 4.23A. Where this happens, there is a textural 
difference where the grains truncate the material, figure 4.23B. Material between grains includes titanite, chlorite, and a glass with a composition similar to illite.
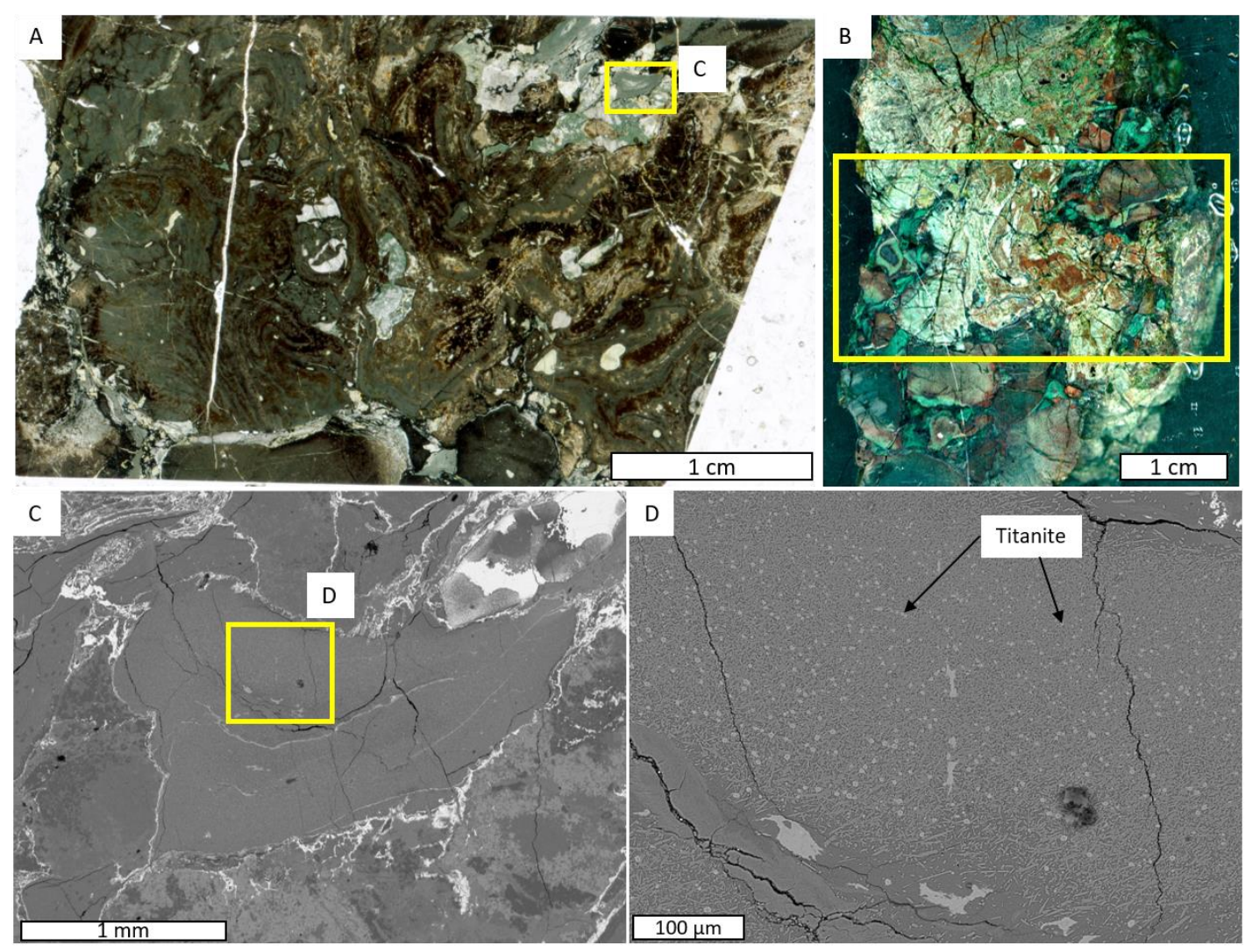

Figure 4.22. Images from sample DOS14.2-S03A. A) Plane polarized thin section image. Yellow box shows the location of C. B) Slab scan of sample. Yellow box shows location of A. C) Backscattered electron micrograph of glassy grain. Yellow box shows location of D. D) Finer scale image of a glassy grain. Titanite is pointed out as circular minerals. 

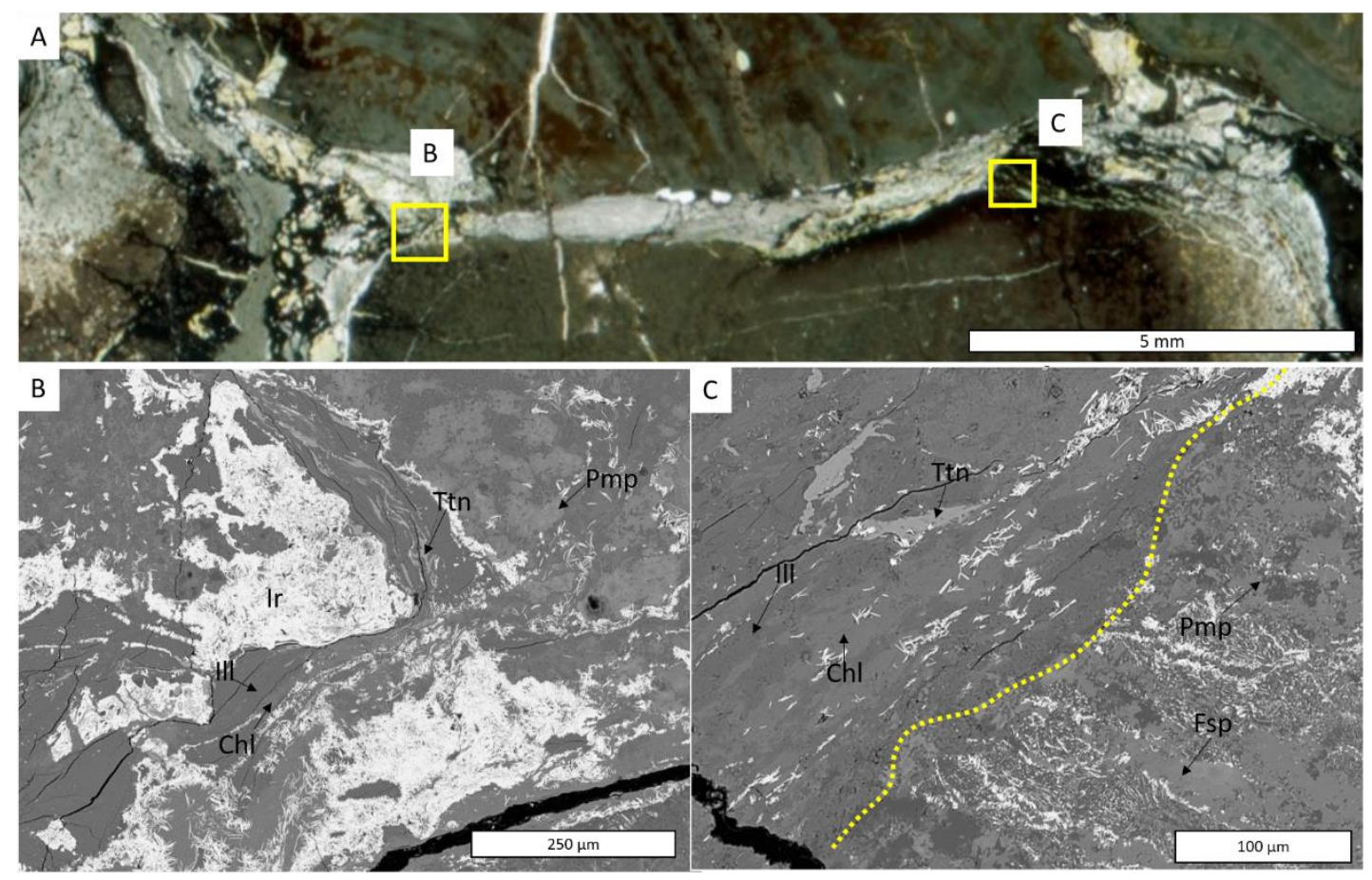

Figure 4.23. Plane polarized thin section and backscattered electron micrograph images from a sample of the red and green clastic rock from outcrop 14.2D (Sample: DOS14.2-S03A). A) Plane polarized thin section image. Yellow boxes show locations of the below images. B) Material flowing into a pointed crevasse. C) Micrograph showing a boundary between two different composition groupings. Yellow dashed line show boundary between flowing material (left) and truncated grain (right). Mineral abbreviations: Illite composition (Ill), Chlorite (Chl), Titanite (Ttn), Pumpellyite (Pmp), Feldspar (Fsp).

Finally, a vein sample was taken from within the red and green material. This sample contains veins of quartz and prehnite interlayered with a mixture of glass grains and basalt clasts. Cataclasite that cuts the sample contains clasts of the host rock in a matrix of iron oxides, figure 4.24. In some parts of the sample, the glassy grains are elongate in the orientation of layering, figure 4.25 , stretching around other surrounding material.

Figure 4.26 highlights examples of quartz bulging in samples in 14.2D. 


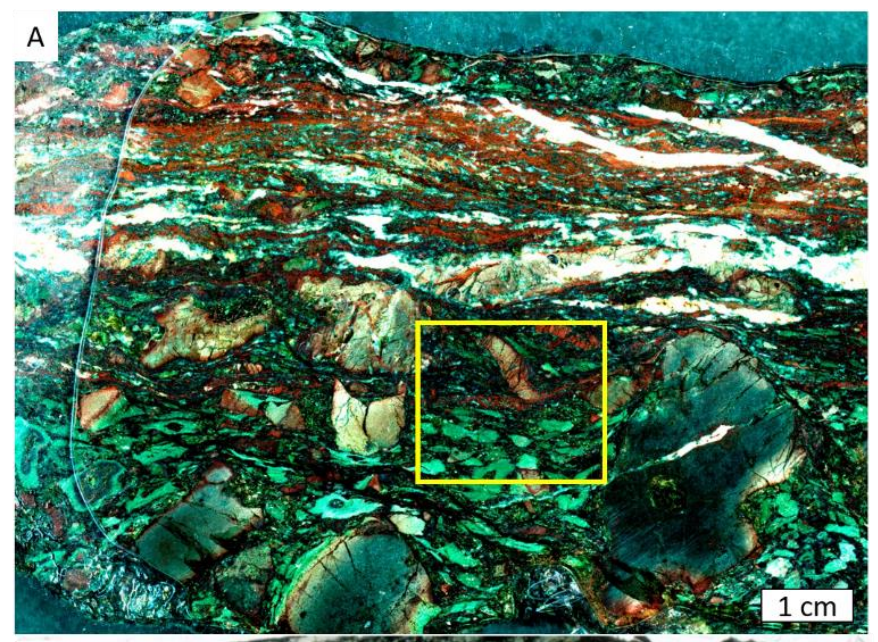

Figure 4.24. Images of sample DOS14.2-S05C A) Slab scan of hand sample. Yellow box shows location of thin section image in B. B) Plane polarized thin section image highlighting the basalt clasts and glassy grains. Yellow box shows location of C. C) Backscattered electron micrograph of clasts within an iron oxide-rich matrix.

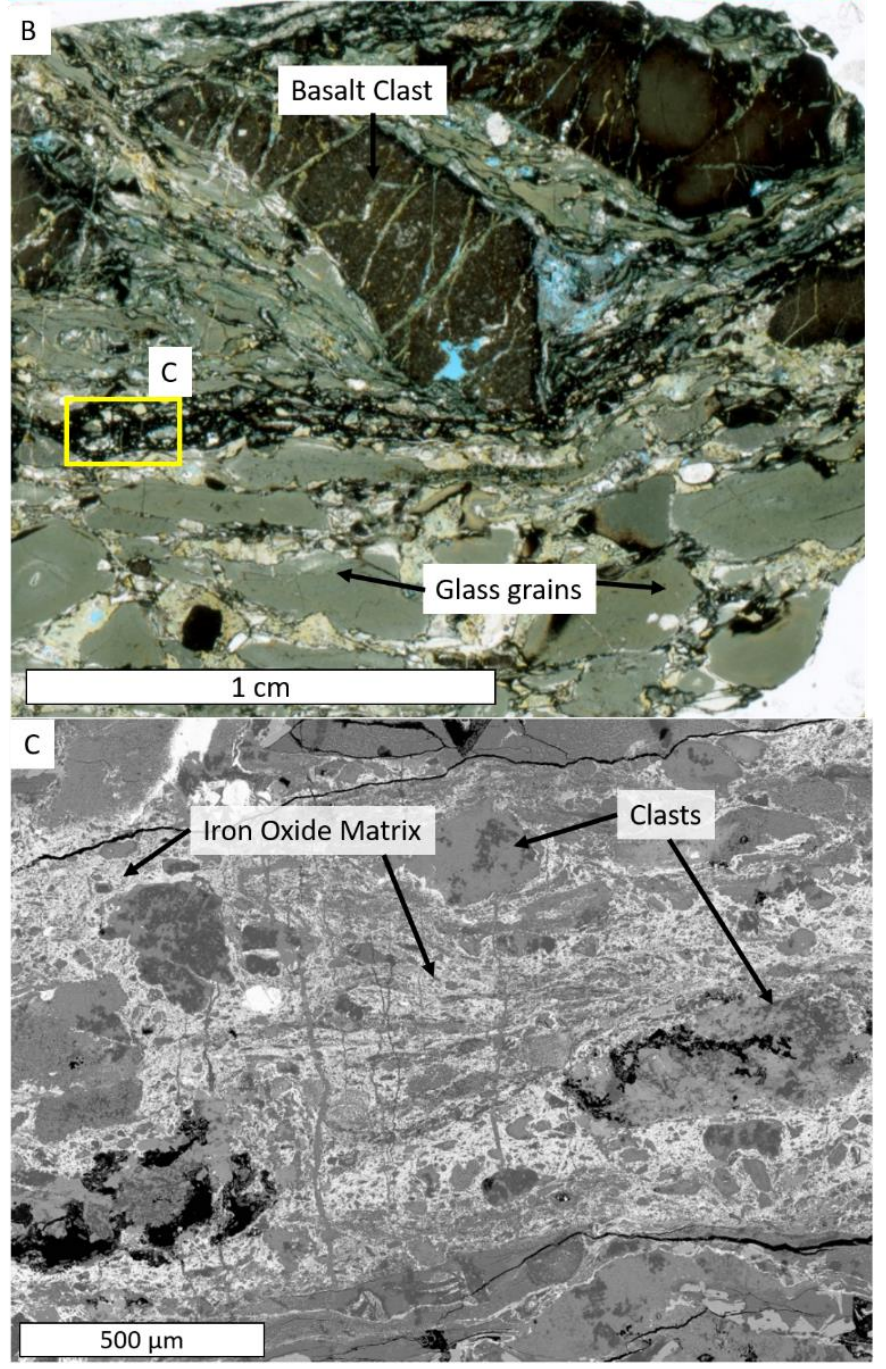




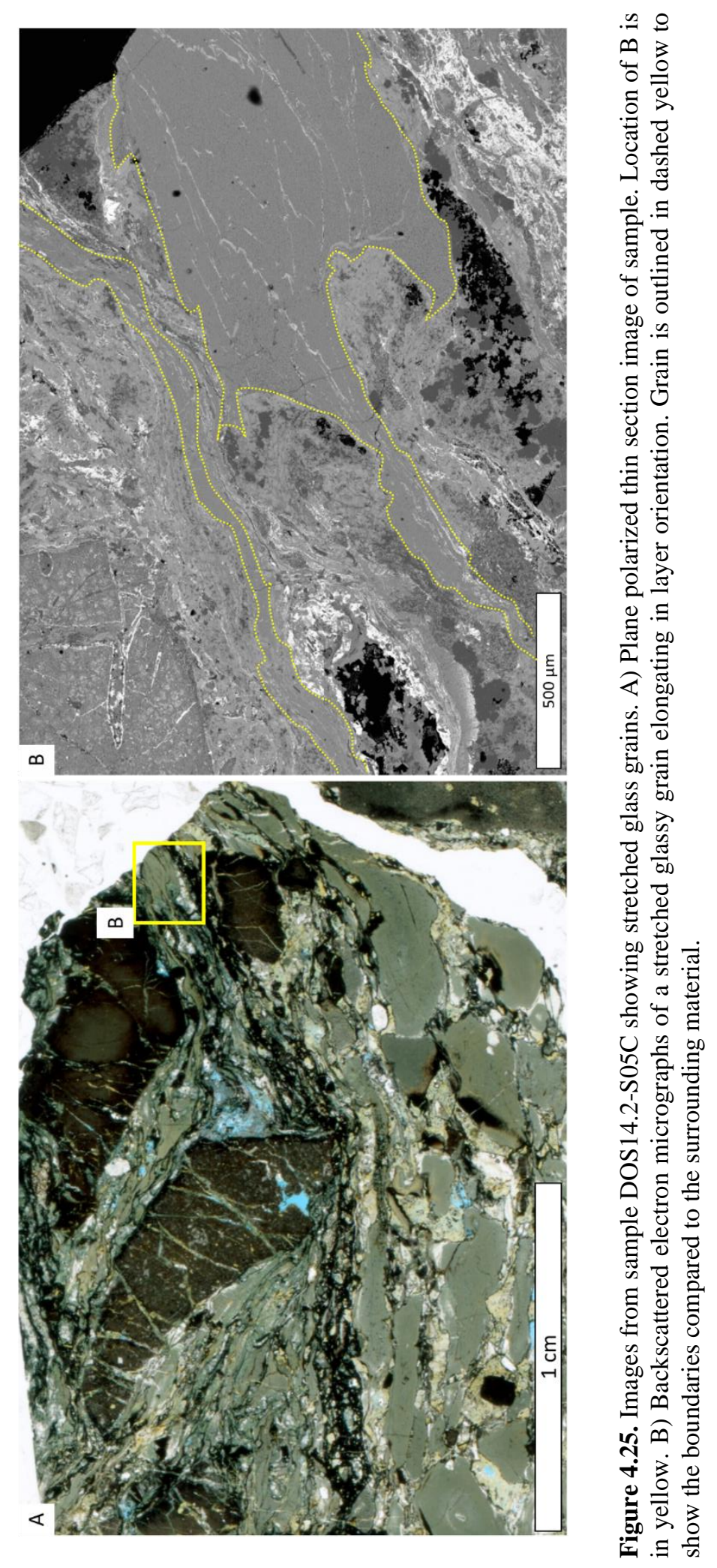




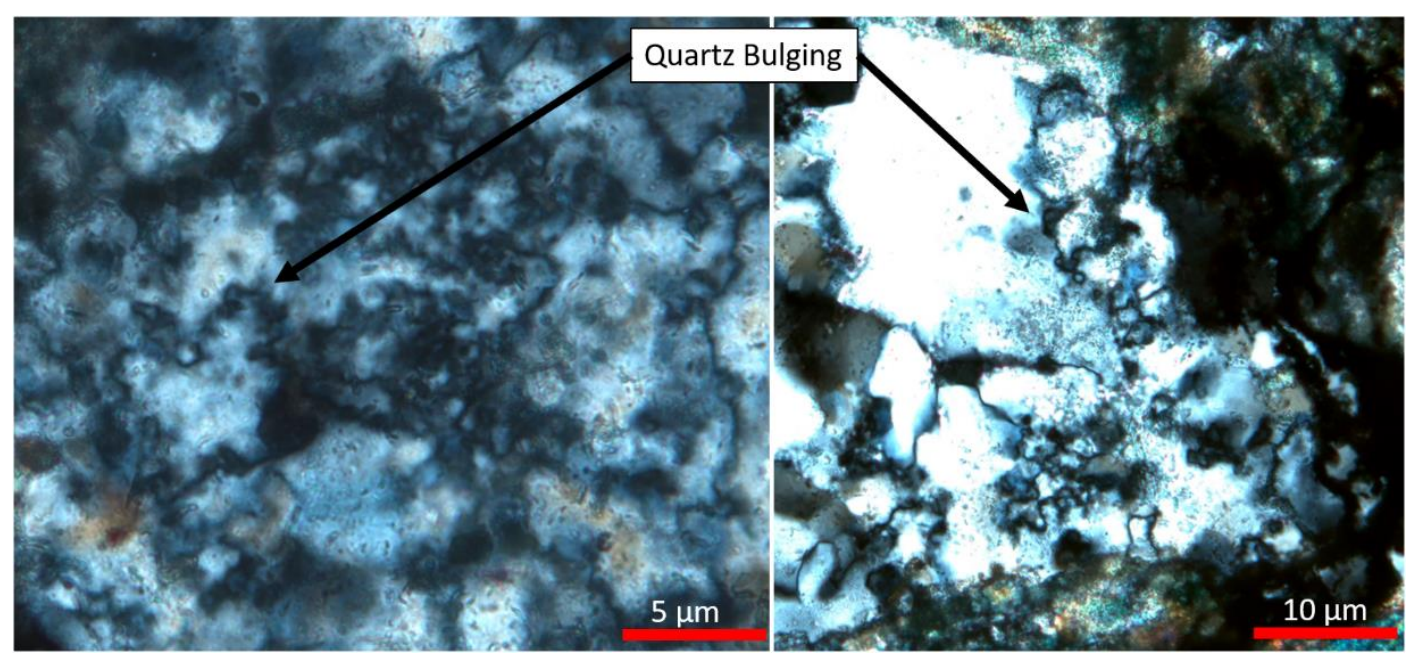

Figure 4.26. Cross polarized thin section images of quartz vein material in samples $14.2-\mathrm{S} 02 \mathrm{~B}$ (left) and 14.2-S10B (right) showing evidence of quartz bulging in outcrop 14.2D.

\section{$\underline{14.2 \mathrm{G}}$}

A pillow basalt sample from $14.2 \mathrm{G}$ contains feldspar phenocrysts in a ground mass of amphibole, feldspar, iron oxides, and pumpellyite; as well as cut small-scale veins. At the microscale, the basalt has a uniform texture of interlocking grains in random orientations, figure 4.27. There are two types of veins ones that contain quartz and pumpellyite and the others containing calcite. 


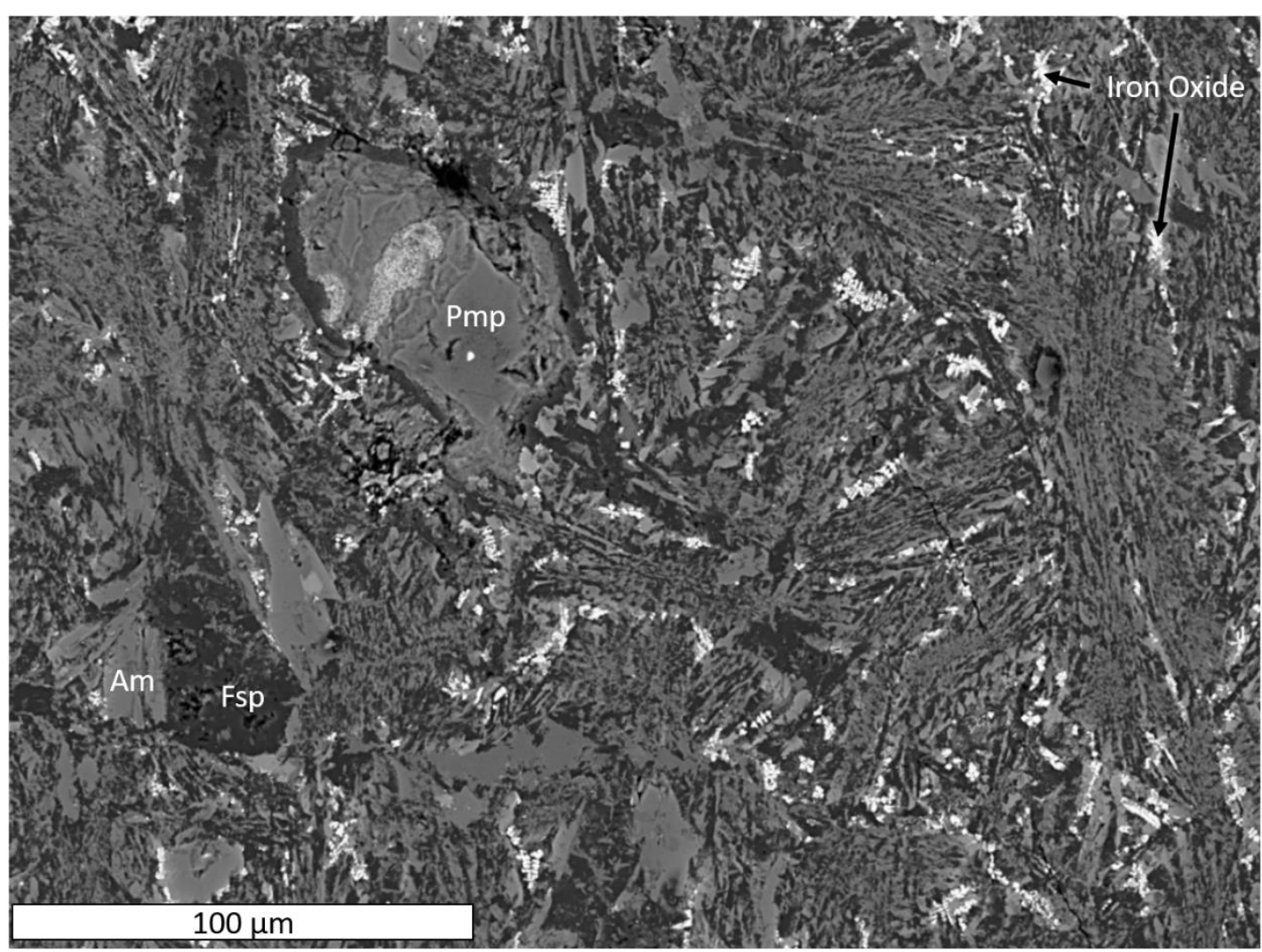

Figure 4.27. SE micrographs of a basalt sample DOS14.2-S011A from $14.2 \mathrm{G}$ showing interlocking grains growing in random orientations.

\subsubsection{Fracture Density}

Table 4.2 shows fracture density calculated by averaging fractures within vertical columns for all counted fractures and the common fracture groups. Common fracture groups include NS and EW trending fractured based on representative populations shown in figure $4.2 \mathrm{~A}$ as $(254,26)$ and $(210,83)$ and observed throughout the entire outcrop. Although not all sections contain EW striking representative planes, EW striking fractures appear throughout the entire outcrop within the measured strike and dip datasets and as sub-horizontal structures observed throughout the outcrop. Section B is omitted from the data because the scale of the images for SfM is not 
comparable to that of the other columns (i.e., 3 meters wide vs. the tens of meters for sections $\mathrm{A}, \mathrm{C}$, and $\mathrm{D}$ ). The fracture density for all counted fractures shows an increase in fracture density from section $\mathrm{A}$ to $\mathrm{C}$ (average of 3.7 at $\mathrm{A} 2$ to 6.3 at $\mathrm{C} 2$ ), then generally decreases towards section $\mathrm{D}$ with a spike of 7 at $\mathrm{C} 4$. A similar pattern is observed in NS and EW trending fractures, where there is an average increase of 3.7 at $\mathrm{A} 2$ to 6.3 at $\mathrm{C} 2$, that generally decreases towards section $\mathrm{D}$ with a spike of 6.7 at $\mathrm{C} 4$. Similar patterns are observed for only the NS trending fractures and only the EW trending fractures. Both data sets show a general increase in density towards $\mathrm{C} 4$, and decrease towards the end of section D. The fracture density graphs for outcrop 14.2 are located and compared to other outcrops in section 0 . Refer to the appendix for individual graphs.

Table 4.2. Fracture density data gathered from outcrop 14.2 that include all counted fractures, NS and EW trending fractures, NS trending fractures, and EW trending fractures. For each type of fracture density is the average fracture density count per square meter and the count range, or difference between the highest and lowest count. Data is separated by section (letter) and column within that section (number).

\begin{tabular}{|c|c|c|c|c|c|c|c|c|c|}
\hline \multirow{2}{*}{ Outcrop } & \multirow{2}{*}{$\begin{array}{l}\text { Outcrop } \\
\text { Section } \\
\text { Column }\end{array}$} & \multicolumn{2}{|c|}{ All Fractures } & \multicolumn{2}{|c|}{$\begin{array}{c}\text { NS and EW } \\
\text { Fractures }\end{array}$} & \multicolumn{2}{|c|}{ NS Fractures } & \multicolumn{2}{|c|}{ EW Fractures } \\
\hline & & $\begin{array}{l}\text { Avg. } \\
\text { Counts }\end{array}$ & Range & $\begin{array}{l}\text { Avg. } \\
\text { Counts }\end{array}$ & Range & $\begin{array}{l}\text { Avg. } \\
\text { Counts }\end{array}$ & Range & $\begin{array}{l}\text { Avg. } \\
\text { Counts }\end{array}$ & Range \\
\hline 14.2 & A1 & 5.7 & 7.0 & 4.3 & 1.0 & 2.3 & 1.0 & 2.0 & 0.0 \\
\hline 14.2 & $\mathrm{~A} 2$ & 3.7 & 4.0 & 3.7 & 4.0 & 2.0 & 2.0 & 1.7 & 2.0 \\
\hline 14.2 & B1 & 35.0 & 0.0 & 18.0 & 0.0 & 14.0 & 0.0 & 4.0 & 0.0 \\
\hline 14.2 & $\mathrm{~B} 2$ & 11.0 & 0.0 & & 0.0 & & 0.0 & & 0.0 \\
\hline 14.2 & $\mathrm{C} 1$ & 5.0 & 8.0 & 5.0 & 8.0 & 2.5 & 3.0 & 2.5 & 5.0 \\
\hline 14.2 & $\mathrm{C} 2$ & 6.3 & 4.0 & 6.3 & 7.0 & 3.0 & 2.0 & 3.3 & 6.0 \\
\hline 14.2 & $\mathrm{C} 3$ & 4.0 & 0.0 & 2.5 & 1.0 & 1.5 & 1.0 & 1.0 & 0.0 \\
\hline 14.2 & $\mathrm{C} 4$ & 7.0 & 3.0 & 6.7 & 4.0 & 3.3 & 2.0 & 3.3 & 3.0 \\
\hline 14.2 & D1 & 3.7 & 3.0 & 3.7 & 3.0 & 1.0 & 0.0 & 2.7 & 3.0 \\
\hline 14.2 & D2 & 3.0 & 2.0 & 3.0 & 2.0 & 1.0 & 2.0 & 2.0 & 0.0 \\
\hline
\end{tabular}




\subsection{Interpretations -14.2}

The BMU is described as sedimentary turbidites interfingering depositional contact with the Crescent Fm. (Einarsen, 1987). The samples taken from the BMU at the westward end of 14.2 (DOS14.2-S06A and DOS14.2-S04A) contain a mixture of volcaniclastics and pillow basalts. The volcaniclastics represent the coarse-grained texture and the pillow basalts represent the fine-grained texture (Figures 4.1 and 4.2A). The microscale data shows a collection of glass particles, which are devitrified to chlorite and other minerals, that pinch and morph around each other (Figure 4.16), interpreted as a subaqueous pyroclastic material, similar to the Tillamook volcanics, which are a complex of subaerial and subaqueous basalt flows and pyroclastics (Avolio, 1973; Jackson, 1983), and welded tuffs from the ancient submarine caldera in the Mineral King Volcanics (Kokelaar \& Busby, 1992). The BMU exposed from this transect is not consistent with what Einarsen (1987) described. These rocks could be an alternative or additional description to components of the BMU.

The black veins with host rock fragments at sections 14.2B-C are cataclasite veins (DOS14.2-S07 and DOS14.2-S08; Figures 4.6 and 4.7C). At section B, flow or slip within the matrix sheared the edges of the larger clasts, indicated by the anastomosing fabric shown in figure 4.18. This generated different clast size within the cataclasite. Within this sample are slip surfaces, or boundaries between different compositions and grain sizes, interpreted to show multiple generations of coseismic ruptures (e.g., Figure 4.19). These boundaries show that the relationship between the veins and fault deformation overprint and are likely mutually cross cutting. Samples 
taken within the boundaries of the red and green clast material contained sparse pyroclastic glass similar to those in section A samples, figure 4.22. These glass grains are overprinted by fault-related deformation seen at the edges of glass grains, figure 4.25.

Cataclasite samples vary in their degree of comminution and recrystallization. This is the case for both the vein samples and clastic rock from outcrop 14.2D. Older cataclasite samples have recrystallized matrixes, typically recrystallized as iron oxide. Varying degrees of comminution come from the grain sizes in the clasts and matrixes. In some samples the slip planes have obvious boundaries, where cataclasite has accumulated in pockets along these planes (e.g., DOS14.2-S09; Figure 4.20), but in the red and green clastic rock that originated from the volcaniclastic BMU, slip planes and their boundaries are more difficult to distinguish within the thin section samples. Evidence for several coseismic ruptures includes overprinting slip planes and differences in cataclasite grain size.

Throughout outcrop 14.2 there is evidence for fluid alteration and mineralization associated with fault damage. The vein samples taken from section D that are interlayered with the host rock are also interlayered with cataclasite slip planes (Figure 4.20 and Figure 4.24). These rocks contain clasts of host rock as well as clasts of vein material, indicating that seismic slip ground up surrounding rock and reworked it into cataclasite. A sample taken from the contact between the yellow matrix and darker matrix in the clastic rock (DOS14.2-S02; Figure 4.21) shows a transition between fluid altered and non-fluid altered material. The non-fluid altered material has 
a fine-grained matrix with rounded to angular clasts, indicative of cataclasite. At the contact, the matrix is altered and contains injections of quartz material between the clasts, where matrix material would be expected. Fluid alteration occurred after faultslip where fluids entered the system and altered and mineralized the matrix (i.e., within sample DOS14.2-S02).

From west to east, outcrop 14.2 shows a transition between the pyroclastic material and pillow basalts of the Crescent Fm. At sections 14.2A and B, there is a mixture of pyroclastics and pillow basalts. At section C, pillow basalts are more prevalent. Section 14.2D shows a mixture of cataclastic rock and pillow basalts, including in the rock material of the clasts in the clastic rock. Section $14.2 \mathrm{G}$ consists of pillow basalts. The contact between the BMU and Crescent Fm. is located between sections $14.2 \mathrm{D}$ and $\mathrm{G}$ (Figure 4.1). Given the observations that pillow basalt contact the BMU at fractured boundaries, the BMU and the basalt may be structurally juxtaposed and variable.

The data and observations support the interpretation there is a regional-scale well-developed fault at section 14.2D, which we name the Ori fault (Figures 4.1 and 4.11). There is an exposed fault core that is subvertical, striking N-S, and outlined by the boundaries between the clast material and host rock. With proximity to section 14.2D there is an increase in fault-related structures at the meso and microscale. The progressive increase in comminution is apparent in sections $14.2 \mathrm{~B}-\mathrm{C}$, noted by the presence of cataclastic veins, as well as outcrop spanning fractures throughout section 14.2A-D. The fracture density reflects this, as there is an increase in average values 
approaching section $14.2 \mathrm{D}$ followed by a decrease at section $14.2 \mathrm{D}$ where the clastic rock is found. The mesoscale increase in fault-related materials is truncated at section 14.2G. The drop off of fault-related structures and differences in the predicted state of stress in section $\mathrm{G}$ further support the interpretation of a fault boundary between $\mathrm{D}$ and $\mathrm{G}$ because if a fault structure is established, deformation localizes along that structure. This would likely promote less fracturing in areas adjacent to the fault structure, particularly if the adjacent rock is rheologically stronger as is the case with the basalt. 
5. Outcrop 13.7 - Fault Structure 2

5.1.Results -13.7

\subsubsection{Field Observations and Fault-Related Structures}

Outcrop 13.7 is located within the Lower Crescent Formation and consists of subvertical pillow basalts with tops to the east. This outcrop was divided into 12 sections (A-L). However, sections A-D were moss covered making the amount of data collection insufficient, as a result this outcrop description begins at section 13.7E.

Figure 5.1 shows a schematic sketch of common structures throughout outcrop 13.7. Because the rock characteristics do not change along the transect to the same degree as outcrop 14.2, sections E through $\mathrm{K}$ of outcrop 13.7 are described together and section $\mathrm{L}$ is described separately.

\section{$\underline{13.7 \mathrm{E}-\mathrm{K}}$}

Sections E-K are densely fractured pillow basalt. On the westward end of the outcrop fractures occur around pillow basalts and curve along the pillow basalt rims., as shown in figure 5.2B. Fractures near the eastern end of the outcrop cut across the pillows, figure 5.2C. Throughout these sections the main fractures orientations trend $\mathrm{N}-\mathrm{S}$ and dip to the west and another set that also strike N-S but dips to the east. There are some areas where fractures are clustered, figure 5.2A, while adjacent pillow basalts do not have as many fractures. Veins found in these sections are not pervasive, typically up to $5 \mathrm{~mm}$ thick, many isolated within pillows and perpendicular to their rims. 


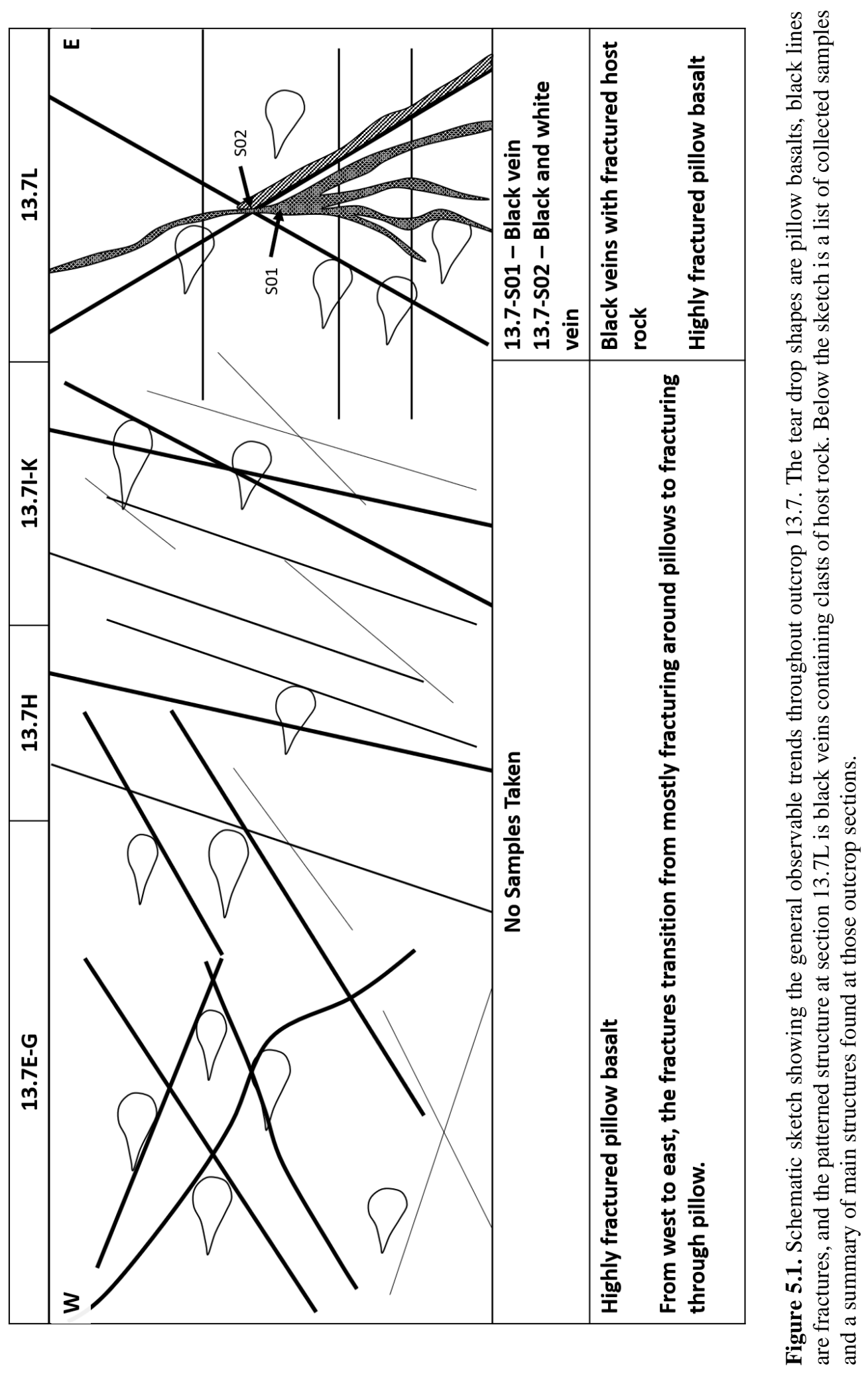




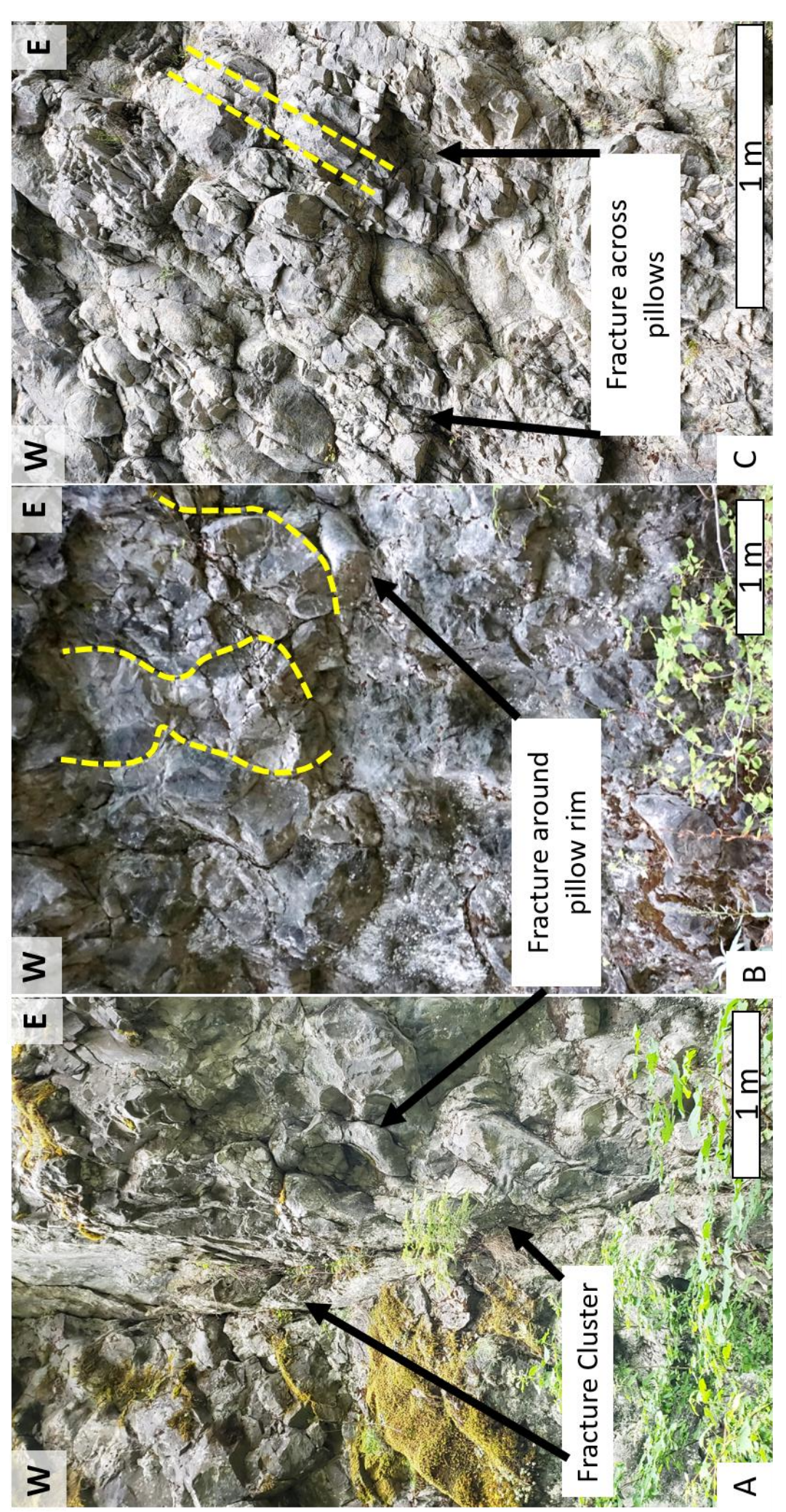

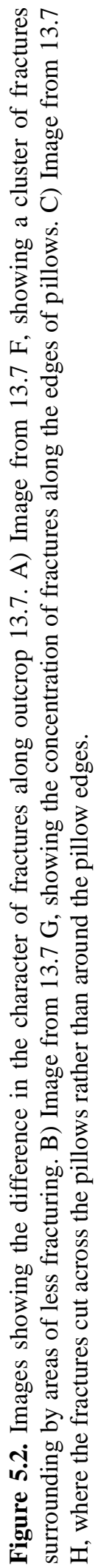




\section{$\underline{13.7 L}$}

Section $13.7 \mathrm{~L}$ is distinctly green in color compared to the western parts of the outcrop and contain both black and white veins (Figure 5.3B and C). Black veins are 1 to $5 \mathrm{~cm}$ in width, with fine-grained (i.e., $1 \mathrm{~cm}$ or less) clasts of surrounding host rock, figure 5.3C. These veins splay like "flower structures" throughout the outcrop. White veins are mineral-filled fractures 1 to $10 \mathrm{~cm}$ in thickness. Some of these veins contain clasts of host rock and cut through the entire section, trending N-S and dipping to the east. Fracturing at this outcrop is pervasive and cuts through the pillows, figure 5.3B, with main fracture groups remaining subparallel and prevalent throughout the section striking N-S and dipping steeply or to the west. 


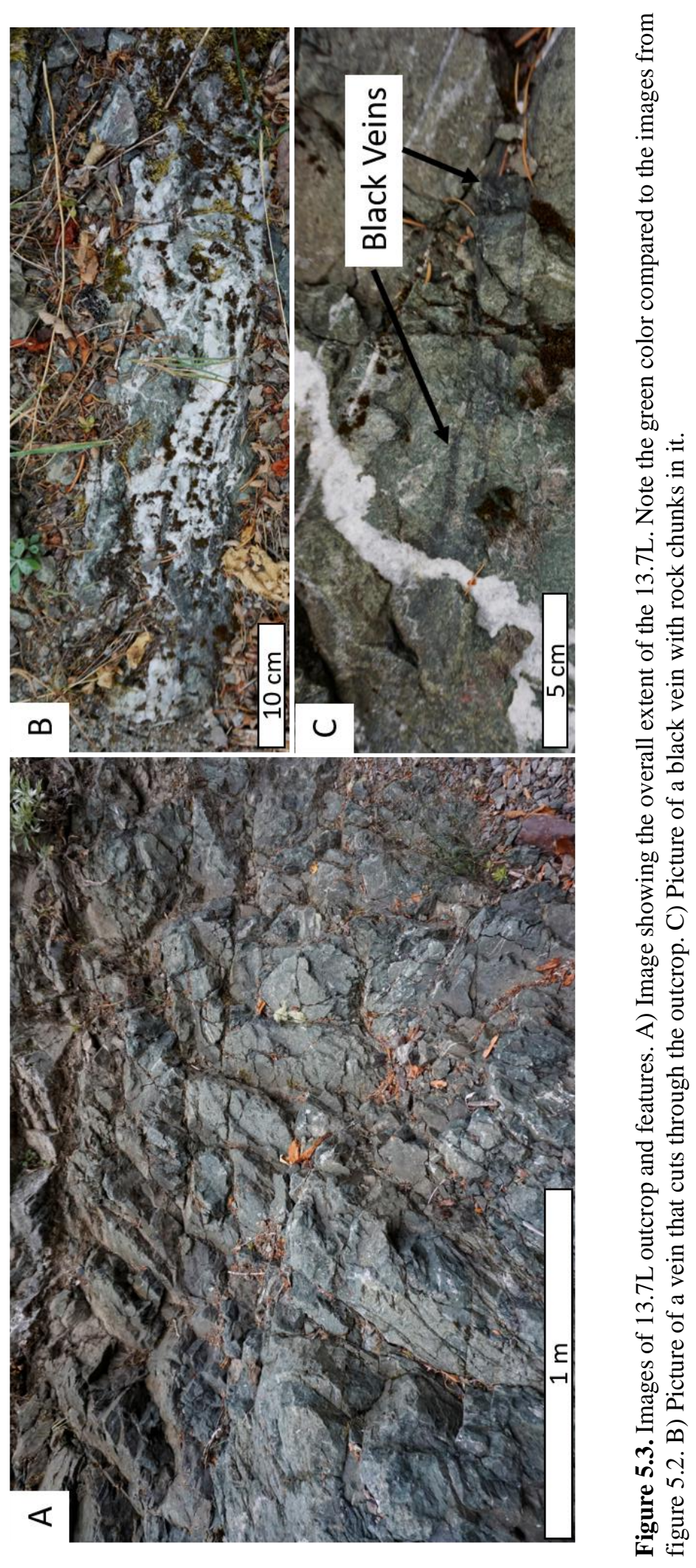




\subsubsection{Orientation Data}

\section{Bedding Orientation}

Bedding orientations were taken from the tops of basalt pillows. The data from the entire outcrop are combined in figure 5.4, and show N-S striking, steeply dipping beds.

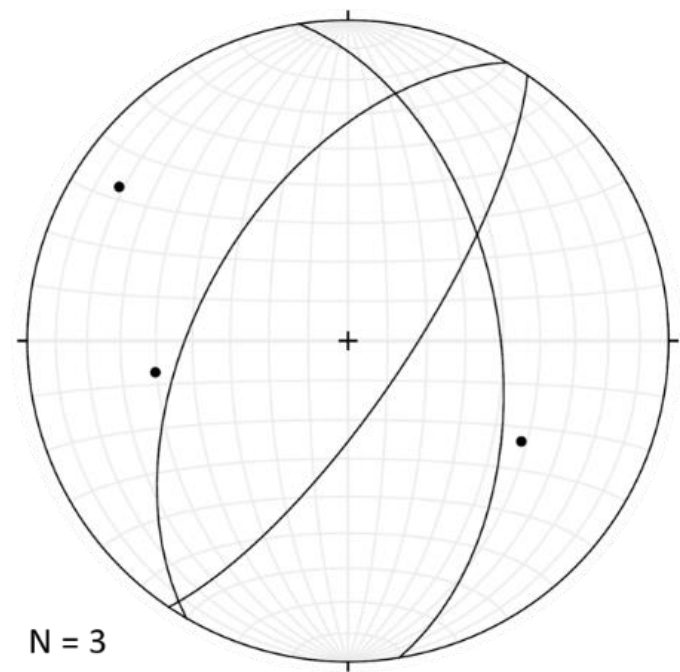

Figure 5.4. Bedding planes and poles from outcrop 13.7. This is an equal area lower hemisphere stereonet.

\section{Fracture Orientations}

The structural orientation data for outcrop 13.7 was broken into five sections to show the change in fracture orientations along the outcrop. From west to east the groups consist of 1) site E, 2) sites F-G, 3) site H, 4) sites I-K, and 5) site L. The representative fracture orientations, their relative acute angles, and predicted Sigma-1 orientations are summarized in Table 5.1. There stereonet figures are located in the 
appendix (Figures $\mathrm{C} 3$ and $\mathrm{C} 4$ ). For $13.7 \mathrm{H}$, the poles from the dataset only revealed one strong fracture group, and therefore a state of stress was not calculated.

Table 5.1. Summary of the fracture representation planes, the acute angle between them, and the calculated Sigma-1 orientation for outcrop 13.7.

\begin{tabular}{|l|l|l|r|l|}
\hline Outcrop Name & Rep Plane 1 & Rep Plane 2 & Acute Angle & Sigma-1 \\
\hline 13.7 E & 238,48 & 78,64 & 71 & $44 \rightarrow 69$ \\
\hline 13.7 F-G & 192,83 & 249,47 & 65 & $234 \rightarrow 31$ \\
\hline 13.7 H & 183,51 & & & \\
\hline 13.7 I-K & 10,54 & 210,36 & 92 & $246 \rightarrow 75$ \\
\hline 13.7 L & 194,35 & 7,89 & 56 & $268 \rightarrow 62$ \\
\hline 13.7 All Data & 32,51 & 192,88 & 42.5 & $49 \rightarrow 56$ \\
\hline
\end{tabular}

When looking at all the calculated representative fracture planes, there are no common fracture orientation planes across the outcrop. Each section has different fracture orientation planes and different predicted Sigma-1 orientations. Overall the representative fracture orientations appear to change in strike from W-E to N-S. If all the fractures were plotted on one stereonet, the fracture representative planes would be orientated at $(35,56)$ and $(192,88)$; and a Sigma- 1 orientated at $49 \rightarrow 56$. Figure 5.5 shows the fracture representative planes and their Sigma-1 orientations. Simga-1 orientations for the outcrop fan along a great circle rather than cluster in a similar area. 


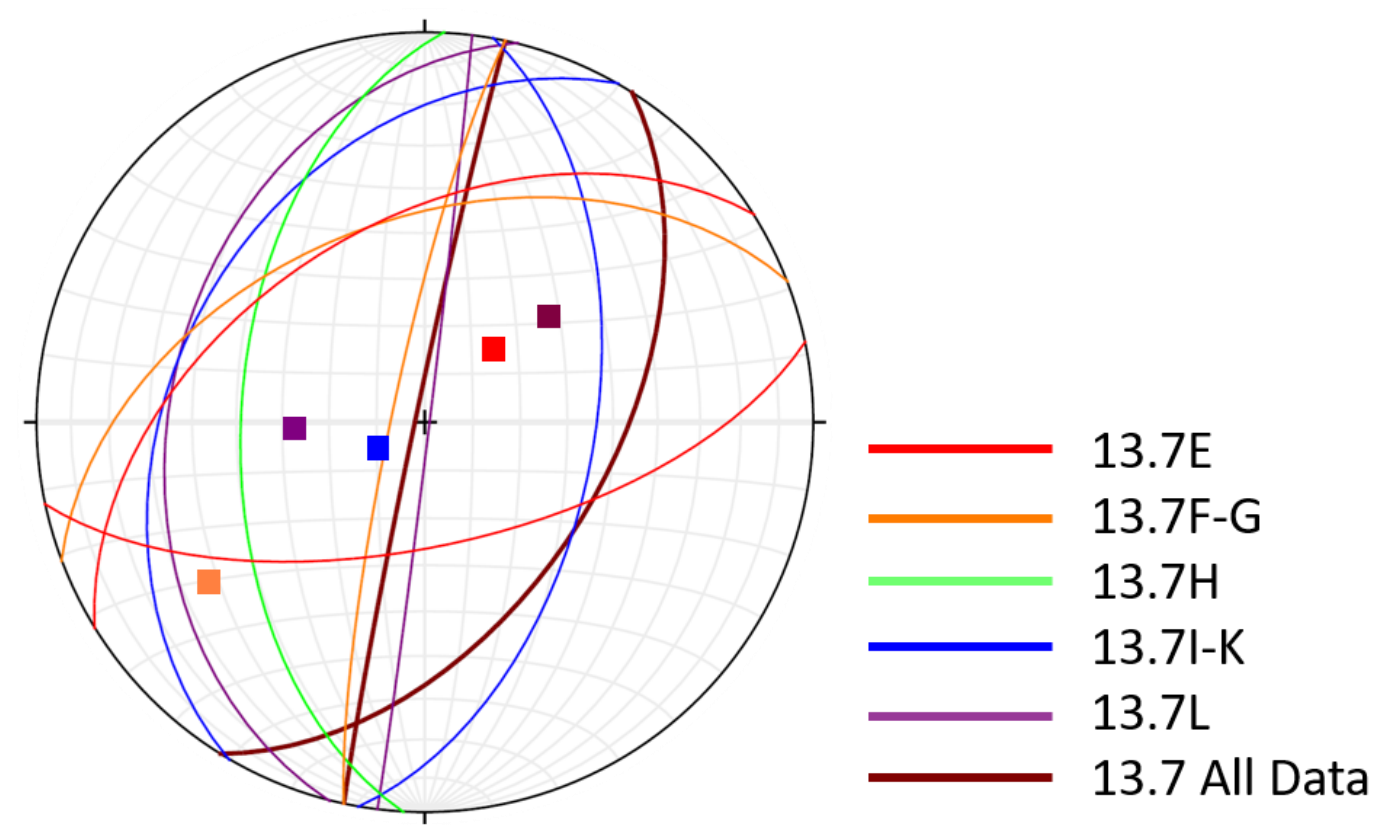

Figure 5.5. Equal area lower hemisphere stereonets of the sectional fracture representative planes and Sigma-1 locations. Red $=13.7$ E. Orange $=13.7$ F-G. Green $=13.7$ H. Blue $=13.7$ I-K. Purple $=13.7$ L. Maroon $=$ All fracture representation.

\section{Vein Orientations}

The vein data for the entire 13.7 outcrop is shown figure 5.6A. These include only the white mineralized veins. Many of the planes have a N-S strike with a few oriented E-W. The pattern of poles fan across the plot rather than cluster figure 5.6B. Figure 5.7 shows the orientations of the black veins with a N-S striking trend, dipping to the east. 

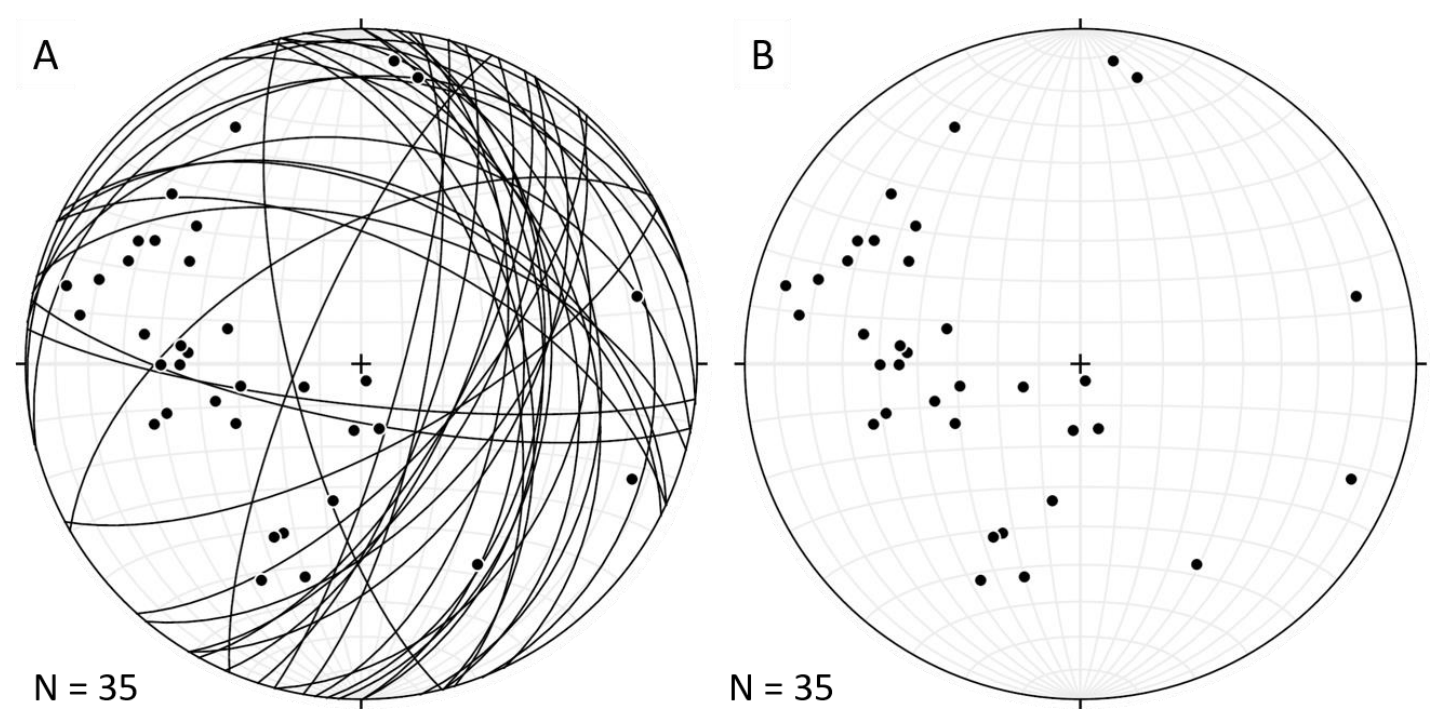

Figure 5.6. Vein plane and pole orientations for outcrop 13.7. A) The plane (black lines) and poles (black dots). B) The poles to the vein planes.

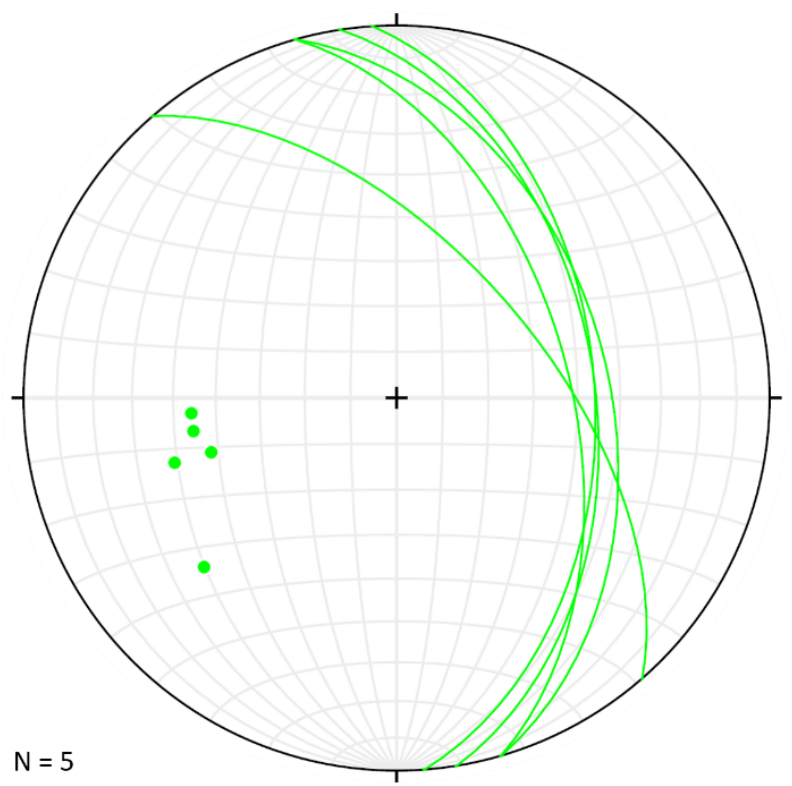

Figure 5.7. Equal area lower hemisphere stereonet showing the collected strike and dip orientation for black veins in outcrop 13.7. 


\subsubsection{Microscale Data and Observations}

Samples collected from section 13.7L focused on the field-identified cataclasite veins (i.e., the black veins). The following minerals were present in the basalt host rock: feldspar, calcite, chlorite*, amphibole, and pumpellyite*. The following minerals were present in the cataclasite vein samples as clasts: amphibole, calcite, quartz, pumpellyite*, and feldspar*. The following minerals were present in the cataclasite vein samples as the matrix: chlorite*, pumpellyite*, epidote*, and titanite. (Note: Asterisks indicate minerals commonly used to identify metamorphic facies). These samples and their associated minerals are discussed in more detail below.

Figure 5.8, figure 5.9, and figure 5.10 show images of cataclasite and pseudotachylyte from outcrop 13.7L. Both types of structures are black and dark grey in hand sample (e.g., Figure 5.8A). Cataclasite veins show clast sizes that vary throughout the samples. Cataclasite shows no banding, and the grain sizes range down from about $25 \mu \mathrm{m}$ to the finest scale, figure $5.8 \mathrm{~B}$, where they are also still distinguishable from each other. 
The pseudotachylyte contains flow bands that deflect around clasts and places where clasts melted in-situ, figure 5.9B and C. Flow bands are defined by zones rich in potassium, titanium, and calcium. Titanite only grows within these bands where there are high concentrations of titanium and calcium. Within the areas where there are K-rich bands, there are no very-fine grained matrix material, but instead devitrified texture. Survivor clasts in the pseudotachylyte are rounded shapes that are the same composition (i.e., chlorite) as the non-potassium-rich flow bands. The clast in the middle of the image, despite having a similar composition with the surrounding material, has a different texture separating it as a standalone clast within the flow.

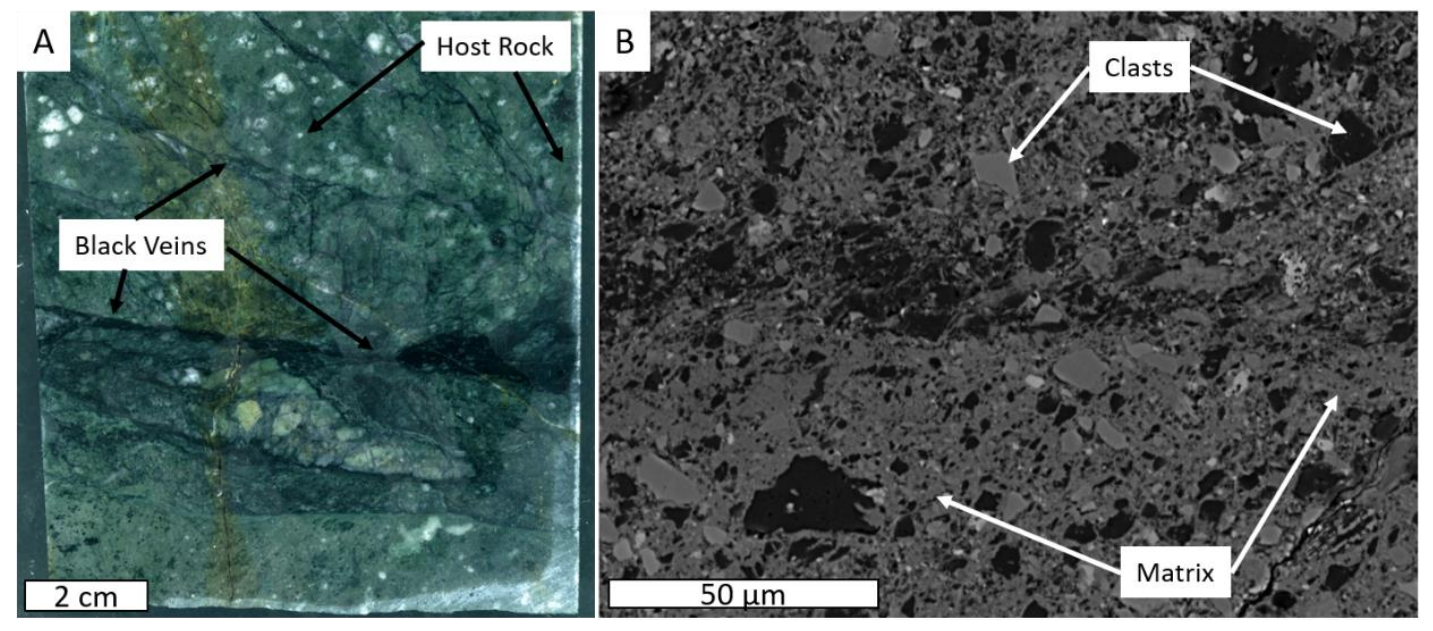

Figure 5.8. Images of sample DOS13.7-S01B. A) Slab scan showing the relationship between the black veins and host rock. B) Backscattered electron micrograph of cataclastic material where there are rounded to angular clasts within a finer-grained matrix. 

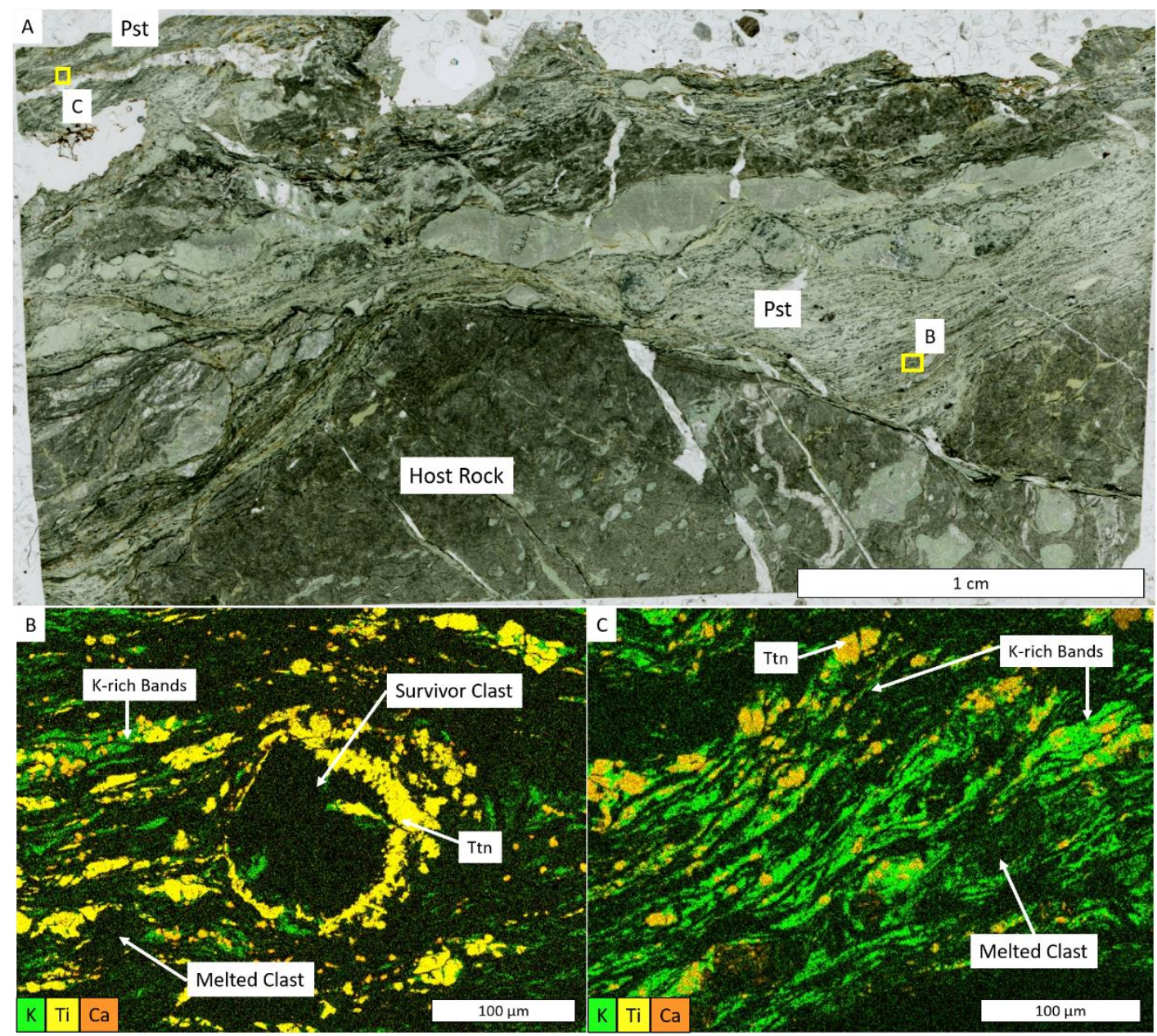

Figure 5.9. Thin section and false colored micrographs of pseudotachylyte from sample DOS13.7S02A. A) Plane polarized thin section highlighting the pseudotachylyte and host rock material. The yellow boxes show the locations of B and C. B) Flow bands, distinguished by titanite, deflect around a survivor clast. The arrow highlights where the K-rich titanite bands deflect around a clast that melted in-situ. Green represents the K-rich bands. Yellow-orange represents titanite. C) Subparallel K-rich flow bands with titanite. Images show EDS derived compositional maps; Ti-yellow, K-green, Caorange. Abbreviation: Pst-Pseudotachylyte, Ttn-titanite. 
None of the minerals throughout the samples show a distinct fabric or preferred orientation that would be consistent with ductile-style deformation. Fabrics are instead local to other microstructures, like folds. For example, quartz veins are folded with the potassium-rich flow bands, figure 5.10A. The surrounding devitrified minerals and banding are locally subparallel to the orientation of the quartz vein fold limbs, figure 5.10B.
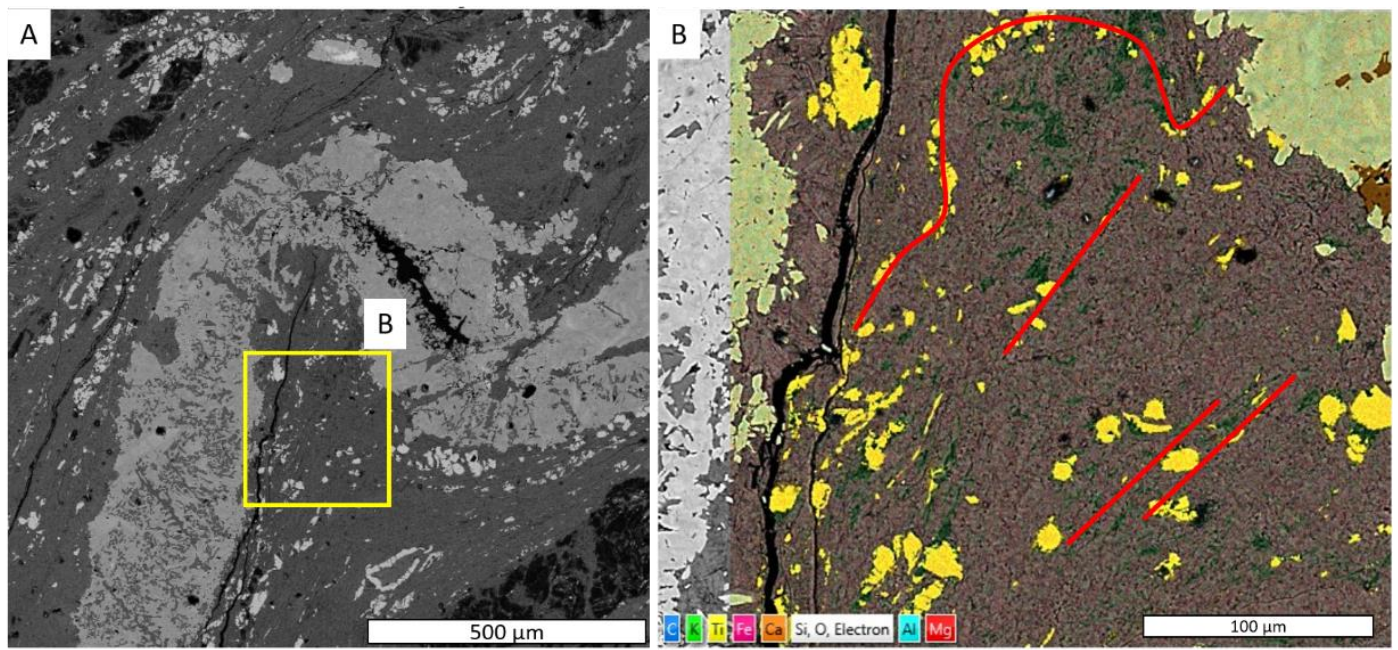

Figure 5.10. Backscattered electron micrograph images of a folded quartz vein (A) in a sample from DOS13.7-S02B. B) A false-colored image of the red box in A. Red outlines show orientations of Krich banding and titanite mineral growth. $\mathrm{B}$ is an EDS-derived compositional map; C-dark blue, $\mathrm{K}$ green, Ti-yellow, Fe-pink, Ca-orange, Al-light blue, Mg-red.

\subsubsection{Fracture Density}

Table 5.2 shows fracture density for outcrop 13.7 for all fractures and common fracture groups (i.e., referred to here as NS and EW striking; based on representative populations shown in outcrop 14.2 [Figure 4.2A]). Representative planes from 14.2 were used as a comparison for outcrop 13.7 because the representative planes for 13.7 varied across the transect. Although EW oriented plane do not appear as representative 
plane, though they do throughout the outcrop. Both datasets show a fluctuation in both the average and range of fracture density. For all the fractures, there is a higher average fracture density at G1, H3, K2/K3, and L1/L3. Of these columns, G1 and L1/L3 have both a spike in fracture density and range of counted fractures. A similar pattern is observed in the fracture density of NS and EW trending fractures, although there a relatively lower average fracture density at site $\mathrm{K}$. The range of the data is generally consistent except for $\mathrm{H} 2, \mathrm{H} 4$, and L2, where the range spikes in value but the fracture density does not.

The NS trending fractures show a more gradual increase in average fracture density from sections $\mathrm{E}$ to $\mathrm{H}$. The spikes in average fracture density occur at $\mathrm{H} 1, \mathrm{I}$, and L3. H1 and I4 also have spikes in fracture count range. EW trending fractures have average density spikes at G1 and L3; however, only G1 also has a spike in range counts. The range of counts vary for both NS and EW datasets, with the larger ranges residing with sections $\mathrm{H}$. The fracture density graphs for outcrop 13.7 are located and compared to other outcrops in section 0 . Refer to the appendix for individual graphs. 
Table 5.2. Fracture density data gathered from outcrop 13.7 that include all counted fractures, NS and EW trending fractures, NS trending fractures, and EW trending fractures. For each type of fracture density is the average fracture density count per square meter and the count range, or difference between the highest and lowest count. Data is separated by section (letter) and column within that section (number).

\begin{tabular}{|c|c|c|c|c|c|c|c|c|c|}
\hline \multirow{2}{*}{ Outcrop } & \multirow{2}{*}{$\begin{array}{l}\text { Outcrop } \\
\text { Section } \\
\text { Column }\end{array}$} & \multicolumn{2}{|c|}{ All Fractures } & \multicolumn{2}{|c|}{$\begin{array}{c}\text { NS and EW } \\
\text { Fractures }\end{array}$} & \multicolumn{2}{|c|}{ NS Fractures } & \multicolumn{2}{|c|}{ EW Fractures } \\
\hline & & $\begin{array}{l}\text { Avg. } \\
\text { Counts }\end{array}$ & Range & \begin{tabular}{l|} 
Avg. \\
Counts
\end{tabular} & Range & $\begin{array}{l}\text { Avg. } \\
\text { Counts }\end{array}$ & Range & $\begin{array}{l}\text { Avg. } \\
\text { Counts }\end{array}$ & Range \\
\hline 13.7 & E1 & 11.0 & 9.0 & 8.7 & 7.0 & 3.7 & 4.0 & 5.0 & 2.0 \\
\hline 13.7 & E2 & 10.3 & 12.0 & 7.3 & 7.0 & 4.3 & 4.0 & 3.0 & 3.0 \\
\hline 13.7 & E3 & 7.0 & 2.0 & 6.0 & 2.0 & 3.0 & 0.0 & 3.0 & 2.0 \\
\hline 13.7 & E4 & 8.0 & 8.0 & 4.7 & 6.0 & 3.0 & 2.0 & 1.7 & 4.0 \\
\hline 13.7 & F1 & 9.0 & 6.0 & 5.0 & 3.0 & 2.7 & 1.0 & 2.7 & 1.0 \\
\hline 13.7 & $\mathrm{~F} 2$ & 8.7 & 7.0 & 5.7 & 6.0 & 3.3 & 3.0 & 2.3 & 3.0 \\
\hline 13.7 & G1 & 22.7 & 17.0 & 9.7 & 7.0 & 3.3 & 2.0 & 6.3 & 5.0 \\
\hline 13.7 & $\mathrm{G} 2$ & 13.7 & 9.0 & 9.3 & 5.0 & 3.7 & 1.0 & 5.7 & 4.0 \\
\hline 13.7 & G3 & 16.0 & 14.0 & 7.3 & 4.0 & 3.7 & 5.0 & 3.7 & 7.0 \\
\hline 13.7 & G4 & 10.7 & 10.0 & 5.7 & 2.0 & 2.3 & 4.0 & 3.3 & 2.0 \\
\hline 13.7 & $\mathrm{H} 1$ & 15.7 & 9.0 & 10.7 & 9.0 & 7.7 & 11.0 & 3.0 & 2.0 \\
\hline 13.7 & $\mathrm{H} 2$ & 17.0 & 11.0 & 13.3 & 13.0 & 8.3 & 8.0 & 5.0 & 5.0 \\
\hline 13.7 & $\mathrm{H} 3$ & 22.3 & 3.0 & 13.3 & 6.0 & 7.3 & 1.0 & 6.0 & 6.0 \\
\hline 13.7 & $\mathrm{H} 4$ & 14.0 & 17.0 & 13.0 & 12.0 & 8.0 & 3.0 & 5.0 & 9.0 \\
\hline 13.7 & I1 & 12.0 & 10.0 & 5.7 & 6.0 & 4.3 & 2.0 & 1.3 & 4.0 \\
\hline 13.7 & $\mathrm{I} 2$ & 17.0 & 5.0 & 5.3 & 3.0 & 3.3 & 4.0 & 2.0 & 3.0 \\
\hline 13.7 & $\mathrm{I} 3$ & 9.7 & 8.0 & 4.7 & 3.0 & 1.3 & 1.0 & 3.3 & 3.0 \\
\hline 13.7 & I4 & 10.3 & 14.0 & 6.0 & 7.0 & 3.7 & 7.0 & 2.3 & 2.0 \\
\hline 13.7 & I5 & 12.7 & 9.0 & 5.0 & 5.0 & 2.7 & 3.0 & 2.3 & 2.0 \\
\hline 13.7 & $\mathrm{~J} 1$ & 10.3 & 11.0 & 1.5 & 1.0 & 1.0 & 2.0 & 0.5 & 1.0 \\
\hline 13.7 & $\mathrm{~J} 2$ & 5.0 & 5.0 & 6.0 & 0.0 & 3.0 & 0.0 & 3.0 & 0.0 \\
\hline 13.7 & $\mathrm{~K} 1$ & 7.0 & 7.0 & 3.3 & 1.0 & 2.0 & 2.0 & 1.3 & 1.0 \\
\hline 13.7 & $\mathrm{~K} 2$ & 20.0 & 0.0 & 3.0 & 0.0 & 3.0 & 0.0 & 0.0 & 0.0 \\
\hline 13.7 & $\mathrm{~K} 3$ & 21.0 & 0.0 & 2.0 & 0.0 & 1.0 & 0.0 & 1.0 & 0.0 \\
\hline 13.7 & L1 & 30.0 & 12.0 & 7.5 & 3.0 & 3.5 & 1.0 & 4.0 & 2.0 \\
\hline 13.7 & $\mathrm{~L} 2$ & 15.0 & 12.0 & 9.0 & 12.0 & 3.3 & 3.0 & 5.7 & 11.0 \\
\hline 13.7 & L3 & 24.0 & 12.0 & 14.0 & 2.0 & 7.5 & 1.0 & 6.0 & 0.0 \\
\hline
\end{tabular}




\subsection{Interpretations -13.7}

The black veins observed at the mesoscale in outcrop $13.7 \mathrm{~L}$ are both cataclasite and pseudotachylyte veins. The microscale confirms the presence of cataclasite based on the angular to rounded clasts within a fine-grain matrix that contains grains distinguishable at the nanoscale. Some of the cataclasite is older, this is evident where the matrix has had time to recrystallize. Though the recrystallized cataclasite looks similar to the fine-grained basaltic host rock, there are clear boundaries between it and the host rock as seen in both the plane polarized thin section images and the backscattered electron micrographs. Pseudotachylyte is distinguished from the cataclasite by the presence of flow banding that is rich in potassium and titanite, rounded survivor clasts around which flow bands deflect, and the very finegrained matrix, where at the finest scale the clasts are not present. The differences in cataclasite texture and overprinting relationships among cataclasite and pseudotachylyte suggest multiple coseismic ruptures.

Within some parts of the pseudotachylyte are veins that appear folded. There is localized alignment of the flow bands following the pattern of the vein folds, implying that veining occurred while the melt was flowing or immediately after when first quenched to glass and that fluids entering the system were related to coseismic rupture. This is further supported by the fact that there is no other evidence of devitrified minerals growing with a preferred mineral alignment, suggesting that post seismic ductile-style deformation did not occur following devitrification . 
Considering section $\mathrm{L}$ as a focal point of seismic activity, there is an increase in fracture density leading to and around section L. In sections E and F, the average fracture density is low. In these sections, the fractures cut around pillows, localizing around the rims instead of through them. In sections H-J, the average fracture density is higher and the fractures in these sections cut through the pillows and around their rims. However, despite the increase in fracture density, a fault core was not found at the 13.7 outcrop; it is either not exposed or does not exist.

This fracture network at 13.7 has a variety of orientations and each section has a different Sigma-1 orientation. When looking at only the Sigma-1 locations, they can be fitted to a great circle orientated at 235,84 , with a pole to that plane as $056 \rightarrow 49$, figure 5.11. This could imply folding of fractures along this outcrop with a Sigma-1 in the SW-NE direction.
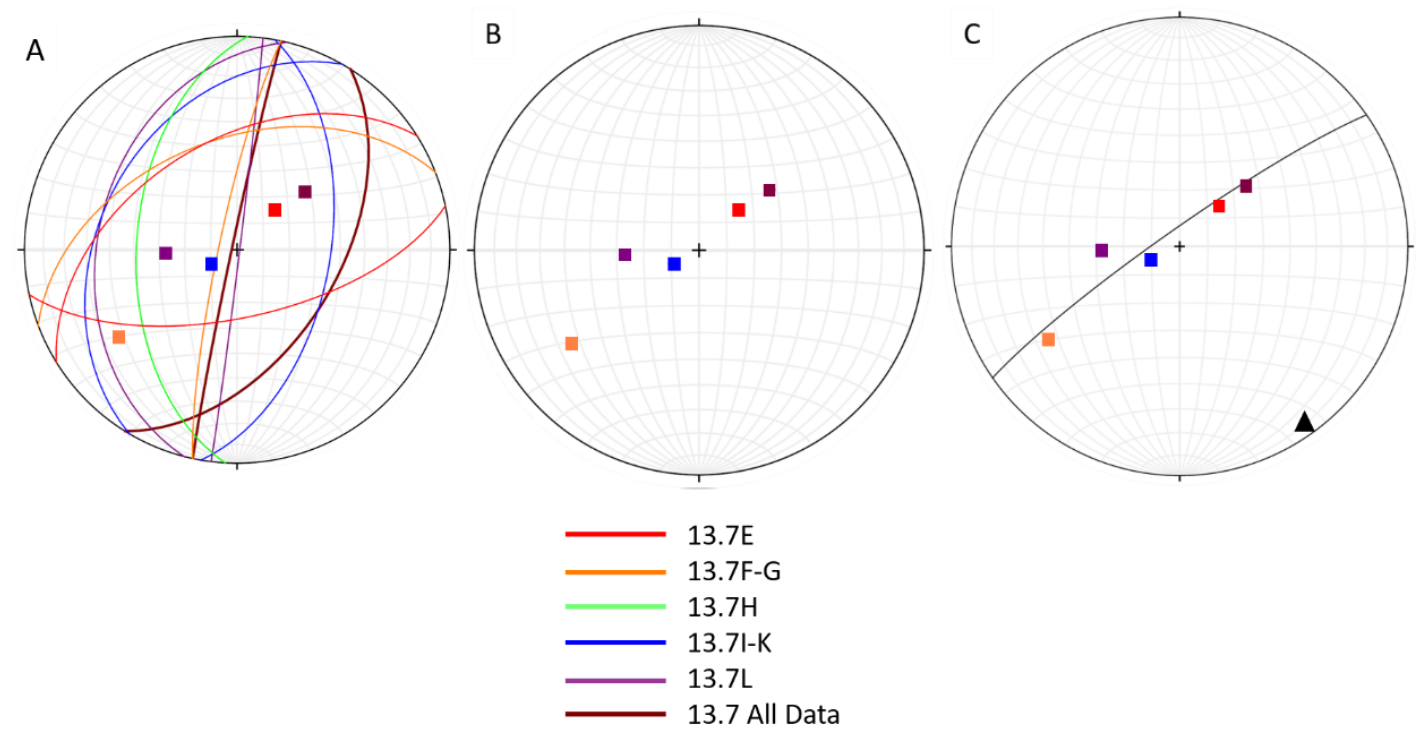

Figure 5.11. Equal area lower hemisphere stereonets of the representative fracture planes (A), Simga1 orientations (B), and interpretative fold axis of fanned Simga-1 orientations (C). 
6. Outcrop 15.1 and 14.9 - Metasediments west of the Hurricane Ridge Fault

\subsection{Results 15.1 - Needle Greywolf Lithic Assemblage}

\subsubsection{Field Observations \& Structure Orientation Data}

Located on to the west of the Hurricane Ridge Fault (Figure 3.1), this outcrop is about 1.5 meters in length and is a planar wall oriented $(193,83)$, figure 6.1A. The representative bedding plane $(195,76)$ is similar to that of the planar side of the outcrop wall. Sedimentary beds are thin, about $1 \mathrm{~mm}$ thick, and alternate between grey and black layers, figure 6.1C. Layers are tightly folded with an axial plane of approximately $(190,78)$ and an undermined north trending plunging hinge. The limbs of the tight folds are also subtly warped (Figure 6.1B). Some fractures cut subperpendicular through this bedding plane and generally strike east-west, while others strike north-south. Representative fracture planes of $(193,83)$ and $(359,17)$ were determined from 19 strike and dip measurements. If these fracture planes are assumed as conjugates, then the predicted Sigma- 1 has a trend and plunge of $110 \rightarrow 55$. Figure 6.2 shows the bedding and fracture orientations for this outcrop. 


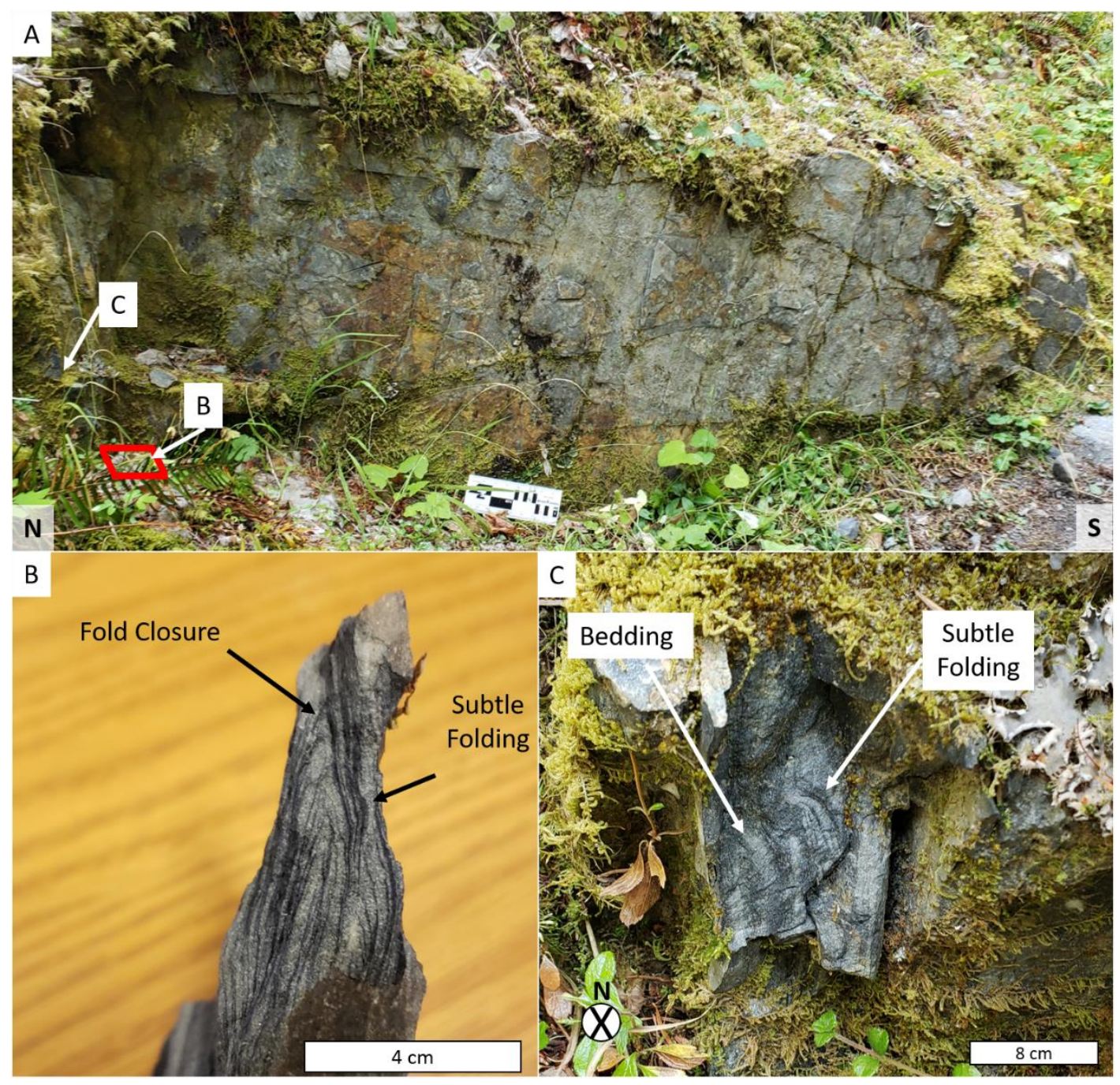

Figure 6.1. Pictures of outcrop 15.1. A) Image that shows entirety of outcrop 15.1. Length of scale card is $20 \mathrm{~cm}$, arrow points north. B) Hand sample taken from red box in image A. Sample DOS15.1S01A has alternating light and dark bedding layers and contains a tight fold with an N-S striking axial plane. C) Image of bedding altering between light and dark colors that also contains subtle folding similar to that of $B$. 

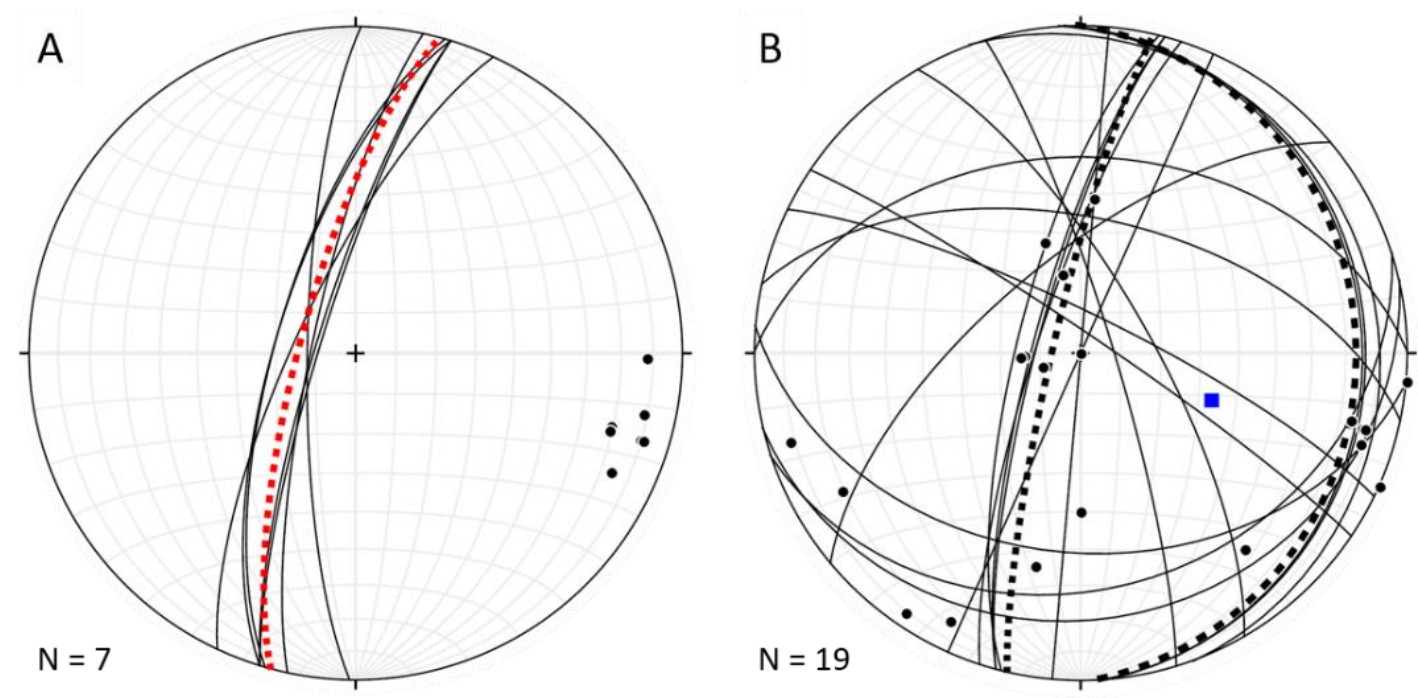

Figure 6.2. Equal area lower hemisphere stereonets of the bedding and fracture data for outcrop 15.1. A) Bedding orientation data. Black lines are the collected strike and dip measurements, red dashed line is the representative bedding plane found from the poles (black dots). B) Fracture orientation data planes (black lines) and poles (black dots). Dashed black lines are the representative planes found from the poles. The blue square is the trend and plunge of the predicted Sigma-1.

\subsubsection{Microscale Data and Observations}

The sample collected from outcrop 15.1 contains alternating light and dark bedding layers that comprise of apatite, chlorite, feldspar, quartz, muscovite, rutile, and zircon. The light layers are defined by rounded feldspar and quartz grains, whereas darker layers are defined by aligned grains of muscovite and chlorite. The sample shows a tight fold closure in thin section, and the dominant foliation orientation is subparallel to bedding. Aligned mica grains of this foliation are also warped, and there are zones defined by the spacing between dissolving quartz grains and a concentration of finer-grained material, suggesting as secondary fabric at an angle to the dominant fabric. 


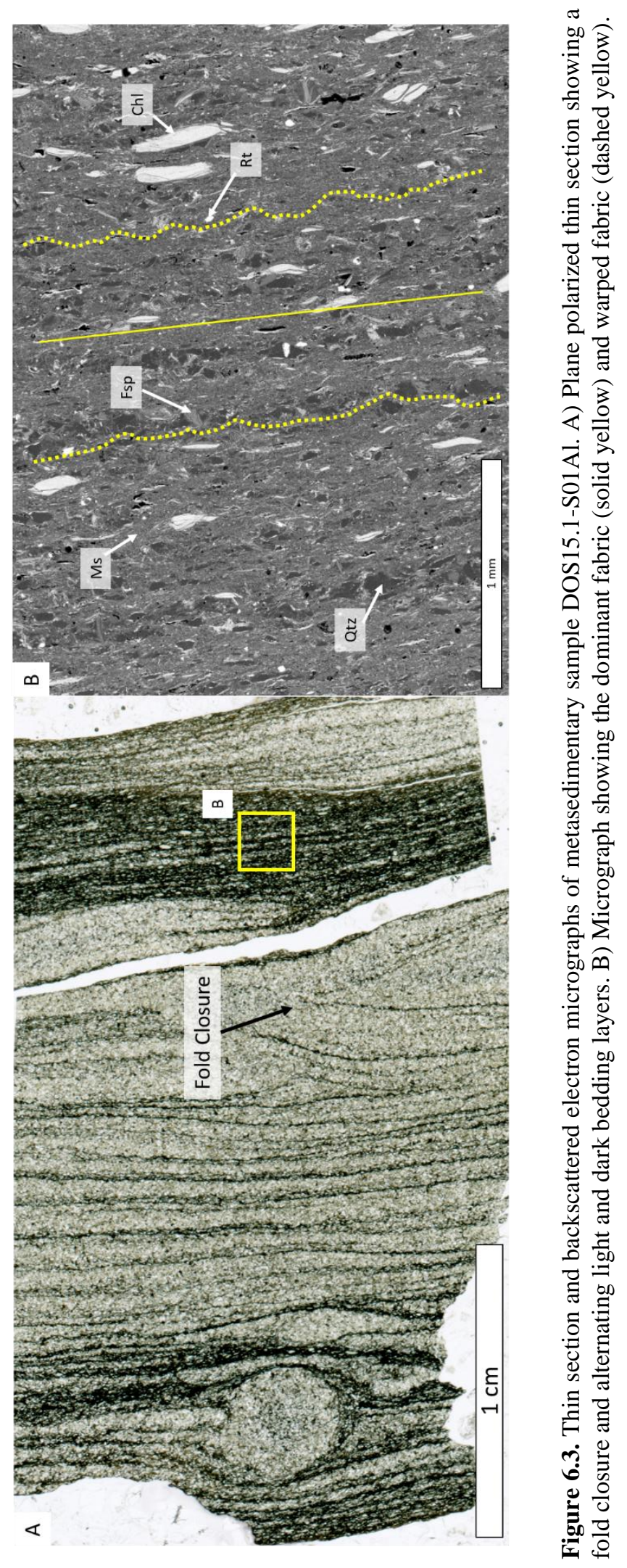

74 


\subsection{Results 14.9 - Needles Greywolf Lithic Assemblage}

\subsubsection{Field Observations \& Structure Orientation Data}

There are two main rock types alternating at this outcrop, slate and metasandstone, figure 6.4A. The western end of the outcrop is dominated by slate whereas the eastern end is dominated by metasandstone. This bedding has a SW-NE orientation, with a representative strike and dip of $(070,78)$. The western end of the outcrop has multiple planes crossing each other to create pencil structures (after Tabor and Cady, 1978). Among the planar structures are a foliation and fractures. There is a foliation between bedding planes striking W-E and steeply dipping, figure 6.4B. Only four foliation orientations were collected and are summarized by two representative planes oriented at $(090,81)$ and $(259,67)$. Fractures strike W-E and have a range of dips. Two representative fracture planes are $(281,72)$ and $(076,73)$. If these fracture planes are conjugates, they would have a predicted Sigma-1 trend and plunge of $56 \rightarrow 268$. Stereonet showing orientation for bedding, fracture, and foliation data are located in the appendix. The eastern end has the same features as the west section; however, the structures are less frequent. It is important to note that this outcrop was exposed by a tree throw, so the orientation measurements are made under the assumption that the outcrop is in place. 

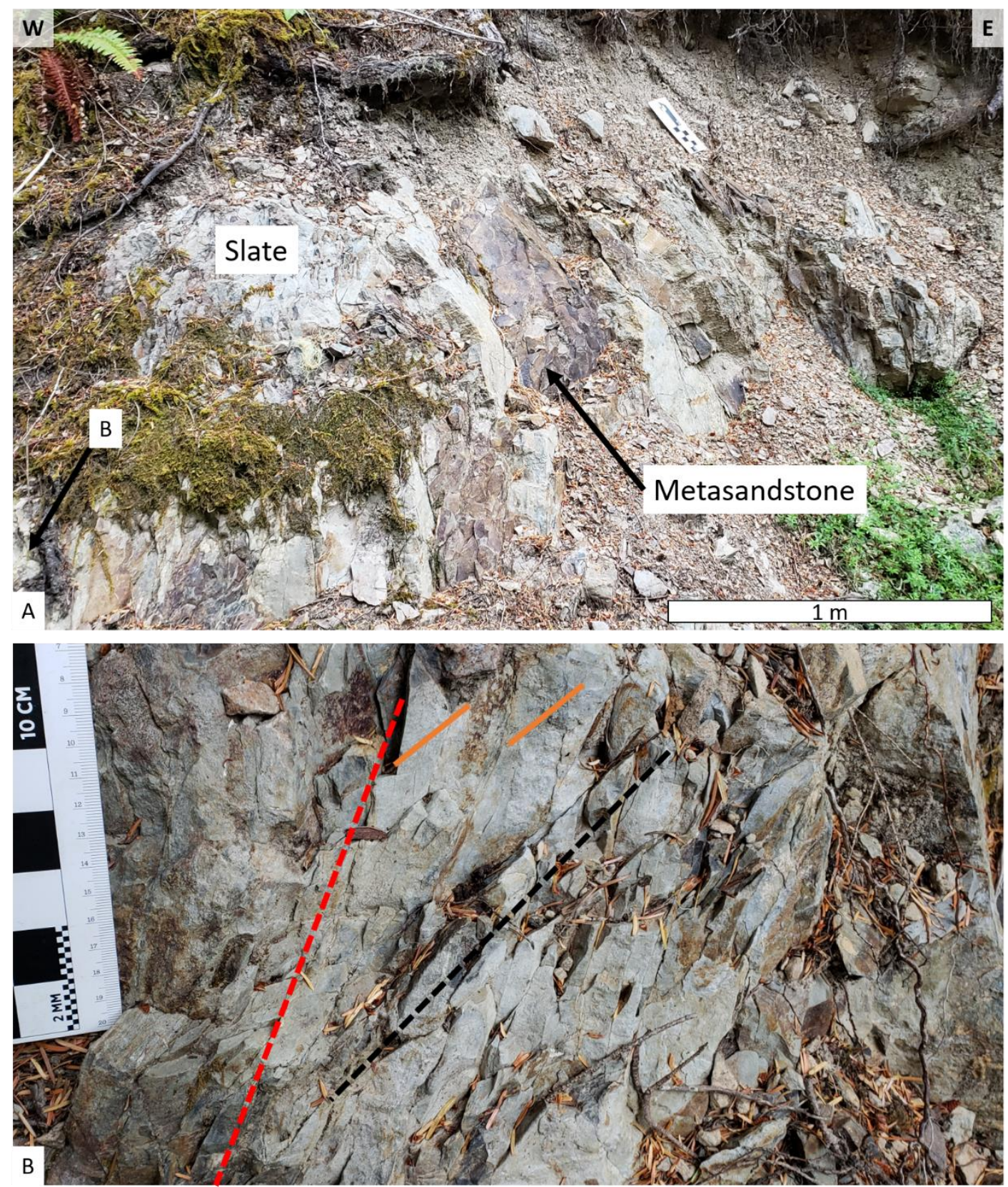

Figure 6.4. Features of outcrop 14.9. A) Image of outcrop 14.9. The western end has majority slate whereas the eastern end has majority metasandstone. B) Features found in the slate. The red dashed lines are bedding planes, black dashed are fractures, and solid orange are foliation. 


\subsection{Interpretations -15.1 and 14.9}

Tabor and Cady (1978) focus their study on characterizing the deformation within the Olympic Mountain sedimentary core, however they do not investigate this transect in their study. Their study produced a map of stereonets divided into zones. The orientation data from outcrop 15.1 matches their Domain 11, which is closest to the outcrop. Both Domain 11 and 15.1 have N-S trending bedding planes steeply dipping to the west.

Tabor and Cady described the rock unit as tightly folded, particularly in the siltstone and shale units. This is accurately reflected at the meso and microscale for outcrop 15.1. At the mesoscale, there is visible tight folding in the outcrop with an axial plane oriented similarly to the bedding planes, where the bedding alternates between quartz/plagioclase and iron oxide rich layers. There were no identifiable foliations at the mesoscale, however, at the microscale there was a dominant foliation that follows the orientation of the bedding layers. The subtle warping of bedding in the hand sample and bending of mineral grains in the thin section suggest additional folding, which is also consistent with observations made by Tabor and Cady (1978) in the vicinity of 15.1 .

The structural bedding data taken from outcrop 14.9 does not match any of the nearby zones from Tabor \& Cady (1978). The bedding orientations in the zones near this transect (i.e., Domain 12) generally strike N-S or NE-SW with steep westward dipping beds and their poles define a northwest trending fold axis. The bedding orientations gathered from this outcrop fit a great circle with an east trending axis. The 
E-W striking foliation data is similar to some of the E-W striking beds, which is consistent with the cleavage data from Tabor and Cady's 1978 work near 14.9 (i.e., foliation and bedding are subparallel). The foliation data is also consistent with a fold with an east trending fold axis. Outcrop 15.1 and 14.9 are close together, about $0.3 \mathrm{~km}$ apart, however, exhibit different bedding orientations. This may suggest that at some point both outcrops had the same orientations and were subsequently affected by deformation altering the orientations in the vicinity of one outcrop and preserving original orientations at the other outcrop, as might be expected with strain localization around the Hurricane Ridge Fault. Alternatively, given the outcrop exposure from a tree throw, the outcrop may not be in place.

\section{Outcrop 11.8 - Crescent Formation}

7.1. Results -11.8

\subsubsection{Field Observations \& Structural Orientations}

Outcrop 11.8 was broken into 7 sections labeled A-G. Sections A, B, and C were largely moss covered. Sections D, E, F, and G have similar features and are considered together. Outcrops are characterized by fractures and white and yellow mineralized veins. At section 11.8 D, there is also yellow fault gouge that connects to a larger exposure of the gouge found in $11.8 \mathrm{E}$ (Figure 7.1). Two fracture representative planes of $(242,58)$ and $(210,51)$ were determined from the fracture poles. If conjugates, then a predicted Sigma- 1 for these fractures is $012 \rightarrow 037$. The stereonet showing fracture orientations is located in the appendix. The veins in outcrop 
11.8 are typically oriented either N-S or E-W and are steeply dipping, figure 7.2. No

bedding orientations were apparent or measured from this outcrop.

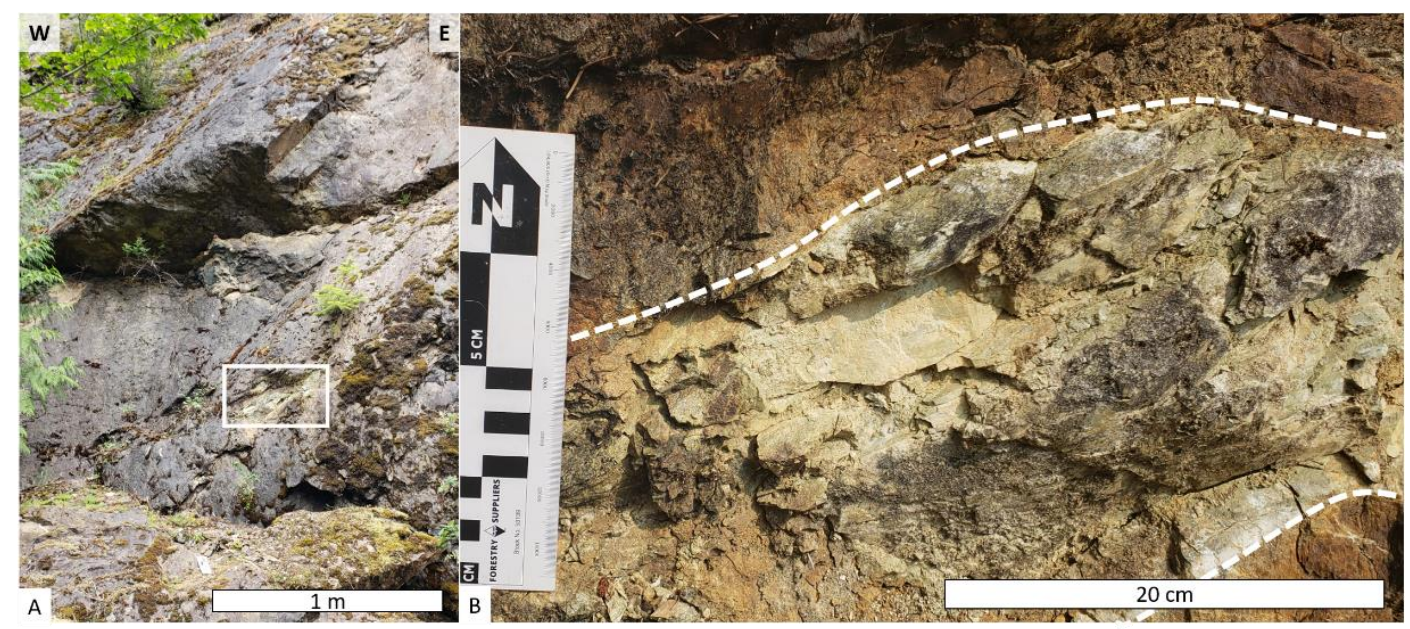

Figure 7.1. Images of the fault gouge found at 11.8. A) Outcrop section image of $11.8 \mathrm{E}$, where there is exposure of the fault gouge, red box. B) Close up image of the fault gouge from the red outline in A.

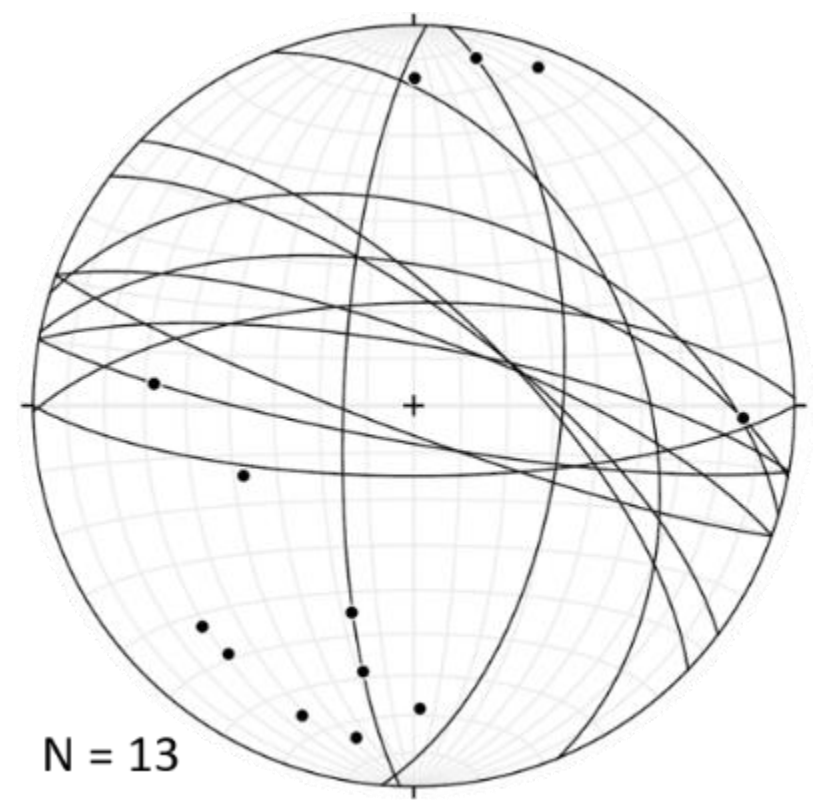

Figure 7.2. Vein plane and pole orientations from outcrop 11.8. Black lines are planes, black dots are poles to those planes. Data are plotted on an equal area lower hemisphere stereonet. 


\subsubsection{Fracture Density}

Table 7.1 shows the fracture density in outcrop 11.8 for all fracture orientations as well as NS and EW trending fracture groups (i.e., referred to here as NS and EW striking; based on representative populations shown in outcrop 14.2 in Figure 4.2A). In general, the average fracture density decreases from east to west, from locality $\mathrm{C}$ to $\mathrm{G}$. The eastern end (towards section $\mathrm{G}$ ) of the outcrop has a larger range of fracture counts as a result of the degree of outcrop exposure.

\subsection{Interpretations -11.8}

Outcrop 11.8 is unlikely to be the type of fault structure observed in outcrops 13.7 and 14.2. The only fault-related structure found at outcrop 11.8 was a yellow consolidated fault gouge material that extended across two outcrop sections. It is, however, unclear how this material is related to nearby fractures. Outcrop 11.8 showed a general decrease to the east in average fracture density. Since sections E-G have the most data, and do not show significant differences in average fracture densities, overall, I interpret outcrop 11.8 to have consistent fracture density, making it a valuable comparison to outcrops 14.2 and 13.7 . 
Table 7.1. Fracture density data gathered from outcrop 11.8 that include all counted fractures, NS and EW trending fractures, NS trending fractures, and EW trending fractures. For each type of fracture density is the average fracture density count per square meter and the count range, or difference between the highest and lowest count. Data is separated by section (letter) and column within that section (number).

\begin{tabular}{|c|c|c|c|c|c|c|c|c|c|}
\hline \multirow{2}{*}{ Outcrop } & \multirow{2}{*}{$\begin{array}{c}\text { Outcrop } \\
\text { Section } \\
\text { Column }\end{array}$} & \multicolumn{2}{|c|}{ All Fractures } & \multicolumn{2}{|c|}{$\begin{array}{c}\text { NS and EW } \\
\text { Fractures }\end{array}$} & \multicolumn{2}{|c|}{ NS Fractures } & \multicolumn{2}{|c|}{ EW Fractures } \\
\hline & & $\begin{array}{l}\text { Avg. } \\
\text { Counts }\end{array}$ & Range & $\begin{array}{l}\text { Avg. } \\
\text { Counts }\end{array}$ & Range & $\begin{array}{l}\text { Avg. } \\
\text { Counts }\end{array}$ & Range & $\begin{array}{l}\text { Avg. } \\
\text { Counts }\end{array}$ & Range \\
\hline 11.8 & $\mathrm{C} 1$ & 14.0 & 0.0 & 14.0 & 0.0 & 13.0 & 0.0 & 1.0 & 0.0 \\
\hline 11.8 & D1 & 8.0 & 0.0 & 8.0 & 0.0 & 6.0 & 0.0 & 2.0 & 0.0 \\
\hline 11.8 & $\mathrm{E} / \mathrm{F} 1$ & 5.0 & 0.0 & 3.0 & 0.0 & 1.0 & 0.0 & 2.0 & 0.0 \\
\hline 11.8 & $\mathrm{E} / \mathrm{F} 2$ & 10.0 & 0.0 & 5.5 & 5.0 & 3.0 & 2.0 & 2.5 & 3.0 \\
\hline 11.8 & G1 & 4.0 & 2.0 & 3.3 & 2.0 & 2.0 & 2.0 & 1.3 & 1.0 \\
\hline 11.8 & $\mathrm{G} 2$ & 4.3 & 6.0 & 3.0 & 4.0 & 1.7 & 2.0 & 1.3 & 3.0 \\
\hline
\end{tabular}




\section{Comparison of Sites Along the Dosewallips Transect}

\subsection{Mineral Assemblage}

Table 8.1 shows the distribution of minerals across the transect. Asterisks indicate minerals used to determine metamorphic facies. Illite is used as a representative mineral composition that best matched the glass composition as determined from backscattered electron energy dispersive analysis. Chlorite, feldspar, and quartz are observed throughout the entire transect samples. Muscovite, rutile, and zircon are only observed within the metasedimentary outcrop. Most minerals observed in outcrops 14.2 and 13.7 are the same with the exception of apatite which was only found in outcrop 13.7 and iron oxides, prehnite, and pyrite which were only found in outcrop 14.2.

Table 8.1. Mineral assemblage from collected samples as listed by outcrop.

\begin{tabular}{|c|c|c|c|}
\hline Mineral & 15.1 & 14.2 & 13.7 \\
\hline Amphibole & & $x$ & $x$ \\
\hline Apatite & $x$ & & $x$ \\
\hline Calcite & & $x$ & $x$ \\
\hline Chlorite* & $x$ & $x$ & $x$ \\
\hline Epidote* & & $x$ & $x$ \\
\hline Feldspar/Plagioclase* & $x$ & $x$ & $x$ \\
\hline Hornblende & & $x$ & \\
\hline Illite (melt) & & $\mathrm{x}$ & $x$ \\
\hline Iron Oxide & & $x$ & \\
\hline Prehnite* & & $x$ & \\
\hline Pumpellyite* & & $x$ & $\mathrm{X}$ \\
\hline Pyrite & & $x$ & \\
\hline Quartz* & $x$ & $x$ & $x$ \\
\hline Titanite & & $\mathrm{x}$ & $\mathrm{x}$ \\
\hline Mica/Muscovite & $x$ & & \\
\hline Rutile & $x$ & & \\
\hline Zircon & $x$ & & \\
\hline Vein Compositions & 15.1 & 14.2 & 13.7 \\
\hline Chlorite & & $x$ & $x$ \\
\hline
\end{tabular}




\begin{tabular}{|c|c|c|}
\hline Quartz & $X$ & \\
\hline Prehnite & $x$ & $x$ \\
\hline Epidote & $x$ & $\mathrm{X}$ \\
\hline Pumpellyite & $x$ & \\
\hline Calcite & $X$ & $x$ \\
\hline
\end{tabular}

*metamorphic index minerals

\subsection{Structures}

Table 8.2 shows the distribution of structures across the transect, which crosses over the Needles Grey Wolf - Blue Mountain Unit (BMU), and Crescent Fm. contacts, transitioning between metasedimentary units to pillow basalts. Foliations were only documented in metasedimentary units of outcrops 15.1 and 14.9 at the hand sample to microscale. Each section shows different representative fracture orientations. Fractures with gouge are limited to outcrops 14.2, 13.7, and 11.8.

Table 8.2. Structures observed in outcrop across the Dosewallips transect. Orientation data listed are the representative planes calculated at each outcrop.

\begin{tabular}{|l|l|l|l|l|}
\hline Structural Feature & $15.1 / 14.9$ & 14.2 & 13.7 & 11.8 \\
\hline Rock Unit & Needles Grey Wolf & BMU/Crescent & Crescent & Crescent \\
\hline Rock & Metasedimentary & $\begin{array}{l}\text { Turbiditic } \\
\text { Volcanics/ } \\
\text { Pillow Basalts }\end{array}$ & $\begin{array}{l}\text { Pillow } \\
\text { Basalts }\end{array}$ & $\begin{array}{l}\text { Pillow } \\
\text { Basalts }\end{array}$ \\
\hline Foliation & $\begin{array}{l}15.1-(195,76) \\
14.9-(090,81) \text { and } \\
(259,67)\end{array}$ & N/A & N/A & N/A \\
\hline Fractures & $\begin{array}{l}15.1-(193,83) \text { and } \\
(359,17) \\
14.9-(281,72) \text { and } \\
(076,73)\end{array}$ & $\begin{array}{l}(212,85) \\
\text { and } \\
(198,25)\end{array}$ & $\begin{array}{l}(32,51) \\
\text { and } \\
(192,88)\end{array}$ & $\begin{array}{l}(242,58) \\
\text { and } \\
(210,51)\end{array}$ \\
\hline $\begin{array}{l}\text { Mineralized Veins } \\
15.1-\text { N/A }\end{array}$ & Yes & Yes & Yes \\
\hline $\begin{array}{l}\text { Fractures with } \\
\text { Gouge/Faults }\end{array}$ & N/A & Yes & Yes & Yes \\
\hline $\begin{array}{l}\text { Cataclasite/ } \\
\text { pseudotachylyte }\end{array}$ & N/A & Yes & Yes & N/A \\
\hline Fault Structure & N/A & Yes & Yes & N/A \\
\hline Fault core & N/A & Yes & N/A & N/A \\
\hline
\end{tabular}

Abbreviations: BMU - Blue Mountain Unit 


\subsection{Fracture Density}

\subsubsection{In-Situ}

In-situ data in figure 8.1 shows the counted fractures per meter at the mesoscale. The average number of fractures per meter varies through the transect. When only looking at the average counts, outcrop 14.2 has the highest in situ fracture counts. The averages are low in the metasediments and the western part of outcrop 13.7 but increases eastward towards 13.7L. The lowest counts are in outcrop 11.8, where there is not much variation in average fractures per meter. Outcrop 14.2 has the highest ranges in average fracture density spanning between 8 and 24. For 13.7 they are between 1 to 20 . Outcrop 11.8 varies in ranges between each section, ranges residing between 0 to 13 . The ranges within outcrop 13.7 consistently reside within 12 to 20 average fracture density with the exception of $13.7 \mathrm{C}$ and $13.7 \mathrm{~K}$.

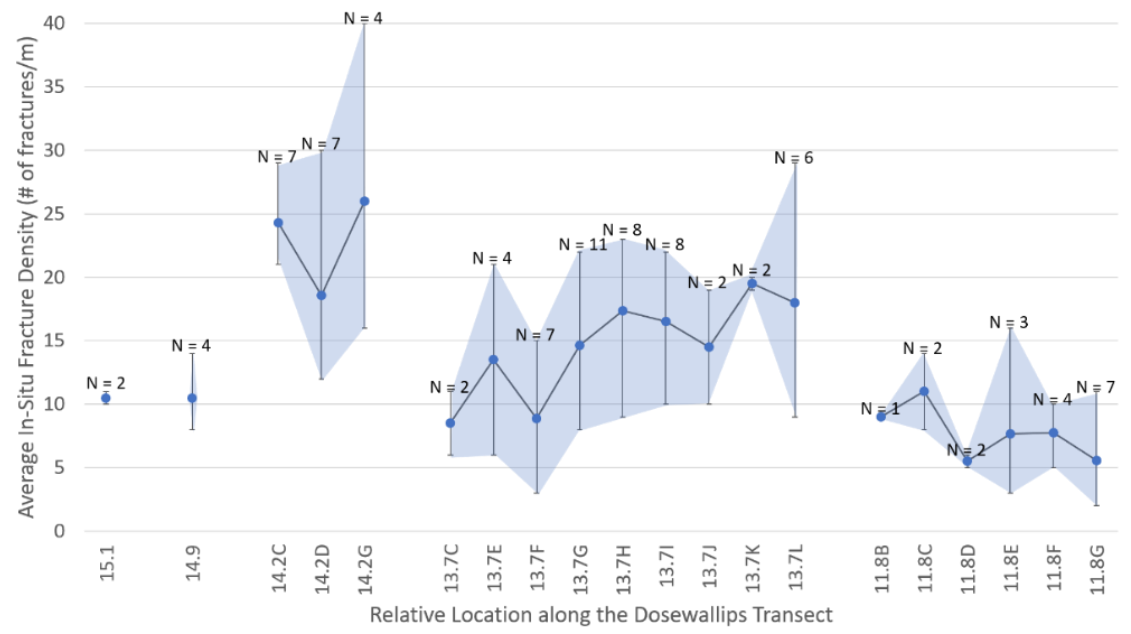

Figure 8.1. Graph illustrating in-situ per meter fracture density. The blue dots show the average fracture density for each outcrop section. The error bars and shaded area show the range in fracture counts for each average count. Spacings between data show breaks in outcrop sections. $\mathrm{N}$ values are the number of lines counted at each outcrop and are above each error bar. 


\subsubsection{Structure from Motion}

\section{Fractures per meter}

Figure 8.2 shows the Structure from Motion derived fractures per meter along the Dosewallips River transect for outcrops 14.2, 13.7, and 11.8. The average fractures per meter does not significantly vary outcrop 14.2 and are the lowest values compared to the other outcrops. Values at outcrop 13.7 are more variable, but generally show higher fracture averages per meter. Outcrop 11.8 differs with a spike in average fracture values at $11.8 \mathrm{C}$, higher than all other outcrops and then decreases to the east. Outcrop 14.2 ranges between 0 and 3. Outcrop 13.7 average fractures ranges between 0 and 7. The average fracture ranges for outcrop 11.8 are between 0 and 2 . The range and average fracture density increases in outcrops $14.2 \mathrm{C}, 13.7 \mathrm{H}$, and $13.7 \mathrm{~K}$.

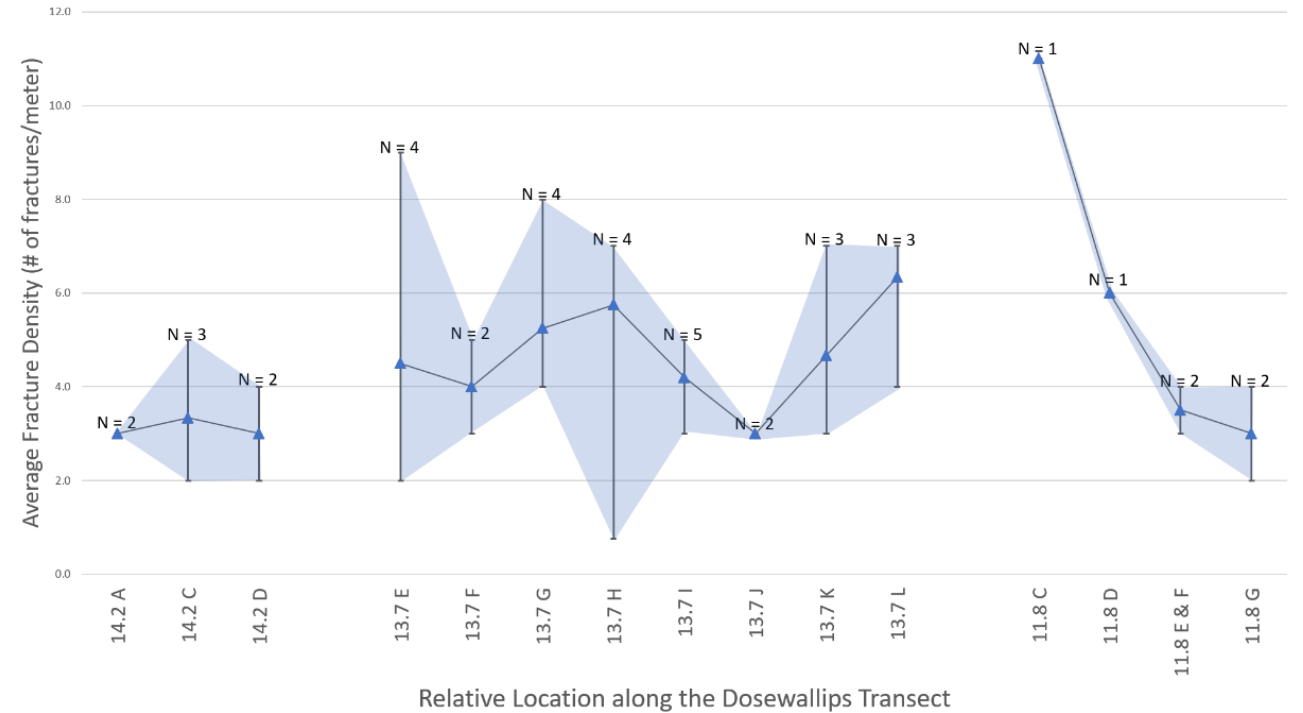

Figure 8.2. Line graphs showing the Structure from Motion derived fractures per meter along the Dosewallips Transect. Blue triangles show the average fracture density for each outcrop section. The error bars show the range in fracture density counts for each outcrop section. Spacings between data show breaks in outcrop sections. $\mathrm{N}$ values are the number of boxes counted at each outcrop and are above each error bar. 


\section{Fracture per square meter}

Figure 8.3 and Figure 8.4 compare the Structure from Motion derived average fracture counts and NS and EW trending fracture along the Dosewallips River transect represented as common fracture groups observed in outcrop 14.2. In figure 8.3, outcrop 13.7 has the highest average fracture density (3-36) counts, particularly at locality $13.7 \mathrm{~L}$, whereas 14.2 and 11.8 have similar average fracture density values (114). The pattern of average fracture density counts is similar in figure 8.4 , where outcrop 13.7 has comparatively higher counts, but the overall values along the transect ranges from 0 to 21 .

The average fracture ranges for the outcrops vary along the transect. Figure 8.3 shows outcrop 14.2 has fracture count ranges that covary with the average fracture density values, both decreasing in value. Within 13.7 , the range increase with fracture density at outcrop $13.7 \mathrm{G} 1$ but decreases with fracture density increase at $13.7 \mathrm{H} 3$. $13.7 \mathrm{~K}$ has the lowest ranges, with some of the higher values of fracture density (2122). In figure 8.4, outcrop 14.2 shows an increase in fracture density and an increase in fracture count range. Outcrop 13.7 also shows this trend with the exception of outcrop 13.7J2, 13.7L1, and 13.7L3. Outcrop 11.8 generally shows an increase in fracture count range with a decrease in fracture density.

Figure 8.5 compares the all fractures with NS and EW fractures, and the difference between the two fracture populations. The main difference between each dataset is the fracture count. Fracture counts for the NS and EW trending fractures are less than the total fractures. Overall, all fracture and NS and EW fracture populations 
show corresponding peaks and troughs in average fracture density. There are places

where the total number of fractures is higher than the common fracture groups, highlighting areas where there is a drop in those fracture groups; the largest difference resides in outcrop $13.7 \mathrm{~K} 2$ to $\mathrm{L} 2$.

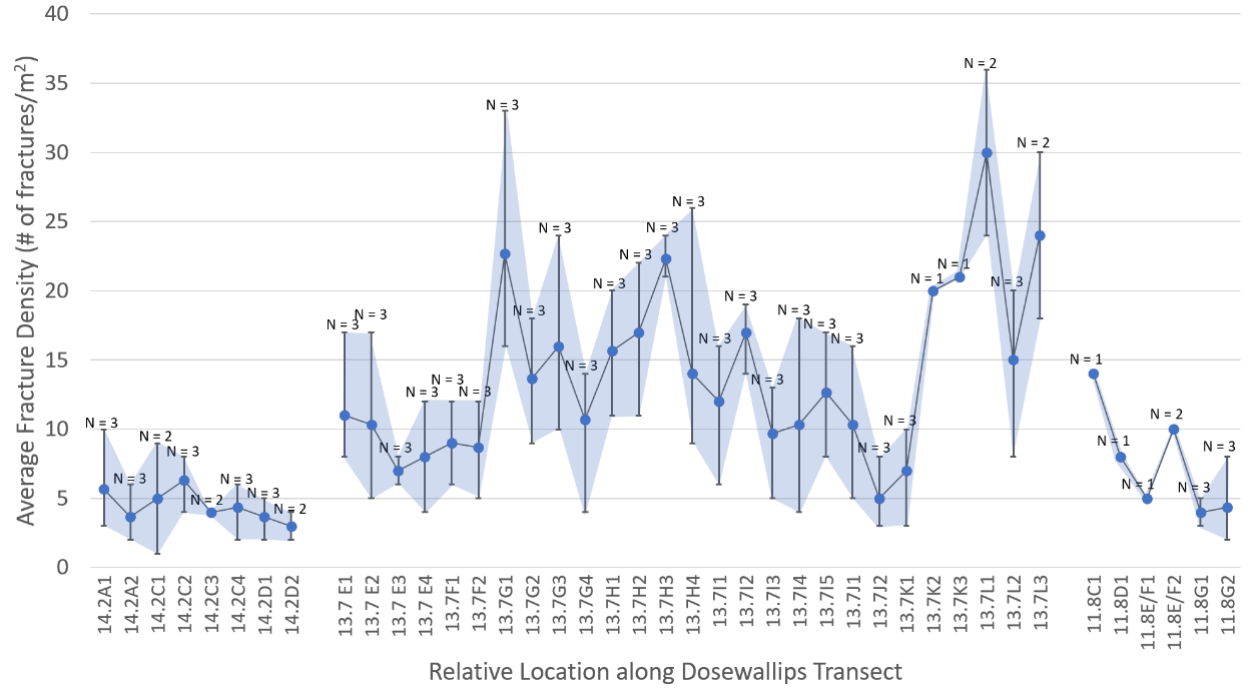

Figure 8.3. Line graphs showing the Structure from Motion derived per square meter fracture density along the Dosewallips Transect. Blue circles show the average fracture density for each outcrop section. The error bars and shaded area show the range in fracture density counts for each outcrop section. $\mathrm{N}$ values are the number of boxes counted at each outcrop are above error bars. Spacing shows breaks between outcrops. 


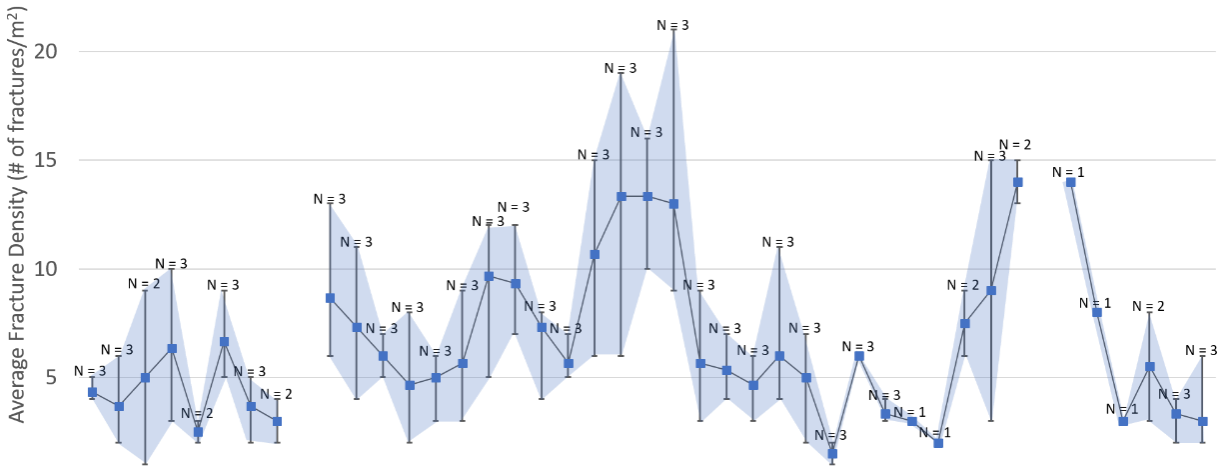

0

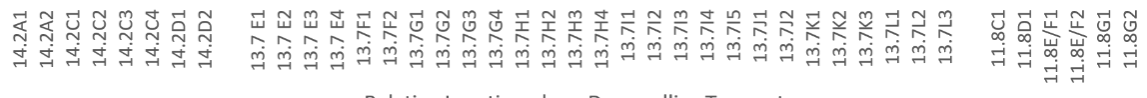

Relative Location along Dosewallips Transect

Figure 8.4. Line graphs showing NS and EW trending Structure from Motion per square meter derived fracture density along the Dosewallips Transect. Blue squares show the average fracture density for each outcrop section. The error bars and shaded area show the range in fracture density counts for each outcrop section. $\mathrm{N}$ values are the number of boxes counted at each outcrop and are above error bars. Spacing shows breaks in outcrops.

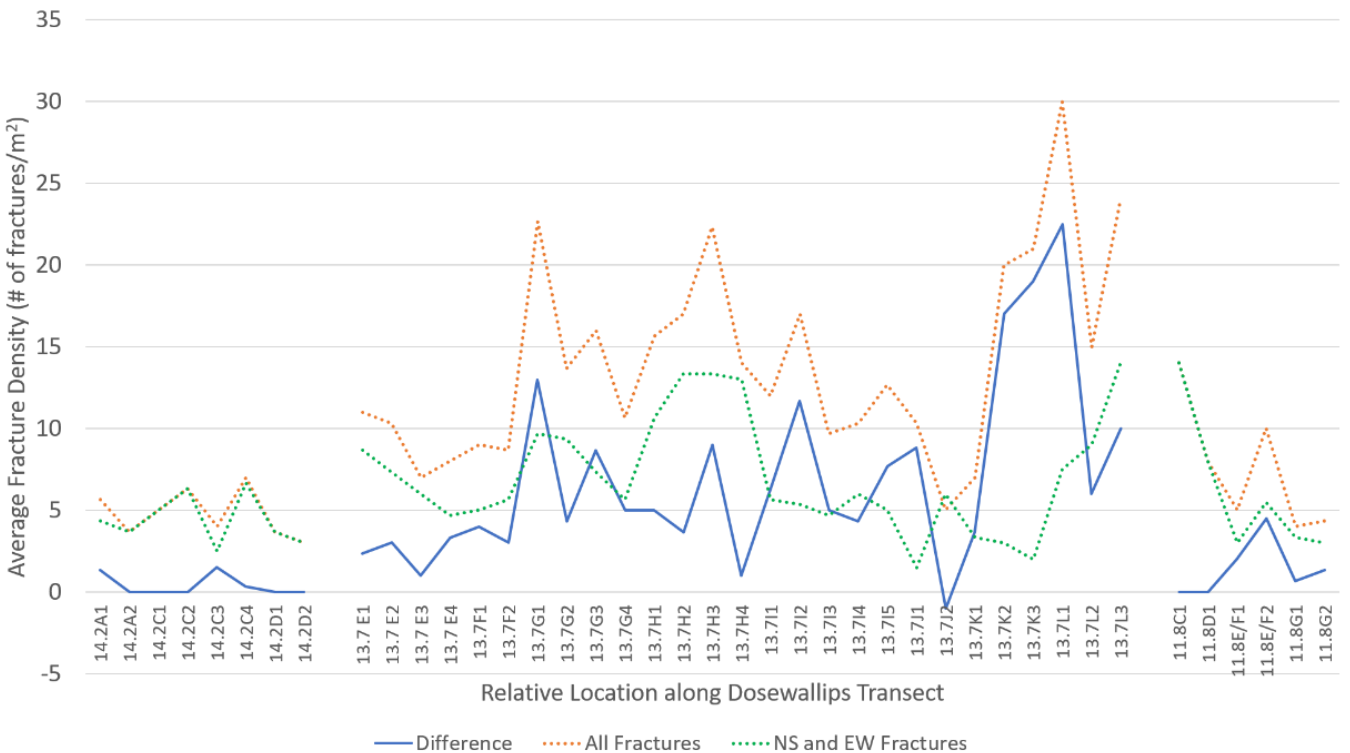

Figure 8.5. Graph comparing the average fracture density of all fracture, NS and EW fractures, and the difference between the two datasets. 


\subsection{Interpretations}

Rock units along the Dosewallips transect contain the metamorphic index minerals chlorite, epidote, plagioclase feldspar, prehnite, pumpellyite, and quartz (Table 8.1). This is consistent with residence at a depth along the boundary between the prehnite-pumpellyite and greenschist facies, about 0-0.6 GPa and $275-300^{\circ} \mathrm{C}$ (Winter, 2010), and is also supported by the presence of quartz bulging at the microscale, figure 4.26 , (i.e., $280-400^{\circ} \mathrm{C}$; Stipp et al., 2002). Outcrop 15.1 has a different mineral assemblage compared with 14.2 and 13.7 because it is a different rock type and explains why other metamorphic index minerals, like epidote, are not found in 15.1. The compositions of veins between outcrop 14.2 and 13.7 are similar except for quartz and pumpellyite are only found in outcrop 14.2 veins. The vein compositions, with the exception of calcite, are metamorphic index minerals. If veins are assumed to appear as a result of fluid infiltration following formation of the fault structures, then the minerals suggest that the fault structures also formed under conditions along the boundary between prehnite-pumpellyite and greenschist facies.

The rock units, structures, and orientations vary across the Dosewallips transect. This study traverses the Needles-Grey Wolf Lithic Assemblage, Blue Mountain Unit, and Crescent Fm. rock units, and some observed structures are specific to the rock unit. For instance, the metasedimentary units at outcrops 15.1 and 14.9 are the only rock units that show a clear foliation because their oceanic sedimentary and micaceous nature are more likely to form foliations. The Blue Mountain Unit in outcrop 14.2 and the cataclasite and pseudotachylyte rocks in outcrop 14.2 and 13.7 
could be foliated, however, there was no evidence to support a consistent alignment of minerals within any of the samples. Fault-related deformation is present in all outcrops of the Crescent Formation, although only outcrops 13.7 and 14.2 display cataclasite and pseudotachylyte. This suggests that fault deformation is related to the fault structures at 13.7 and 14.2, where 14.2 has a clear fault structure, including a fault core, and 13.7 is either a continuation of the Ori fault at outcrop 14.2 or a new, separate fault structure. All rock units are fractured and contain mineralized veins. However, the type of veins that are present varies across the transect and is related to whether or not the outcrops contain fault structures. For instance, outcrops 14.2 and 13.7 contain cataclasite and/or pseudotachylyte in association with the veins. The distribution and presence of veins and fault structures across the transect indicates that fluid infiltrated along the entire transect but is more localized around fault structures filling in void spaces created from fault-related deformation.

The orientation of fractures along the transect also highlight differences between outcrops in the transect. Each outcrop has its own representative fracture planes and generally strike N-S for outcrop 15.1, 14.2, and 13.7, and SW-NE in outcrop 11.8. There is a clear difference within outcrop 14.2 where sections A-D have a different orientation than eastern most section G (Figure 4.14). This suggests the presence of a fault that creates the difference and is consistent with the fault core found at 14.2D. A similar difference in orientations is not apparent between 13.7E-K and 13.7L, figure 5.5, where cataclasite and pseudotachylyte occur, which could indicate that fractures in $13.7 \mathrm{E}-\mathrm{K}$ are not related to the formation of cataclasite and 
pseudotachylyte at $13.7 \mathrm{~L}$. However, the outcrop sections in 13.7 all have different fracture and Sigma-1 orientations that could be a result of other causes, such as localized folding (i.e., predicted Sigma-1 orientations could fit a great circle as expected for the poles of folded planes; Figure 5.5).

Data was collected from 11.8 to document potential background deformation with respect to fault-related structures in the adjacent outcrops. The orientations of many fractures form 11.8 are similar to those of 14.2. This could suggest that the fractures in 11.8 were made by the same state of stress as $14.2 \mathrm{G}$, potentially showing early deformation preserved by the fault and seismic activity occurring at 14.2 and 13.7. However, the fracture orientations differ between all the outcrops to conclusively define a fracture population as background fractures vs. fractures that could be associated with the fault.

The fracture density graphs show the variation of fractures along the transect. Overall, the datasets (i.e., all fractures vs. NS strike oriented vs. EW strike oriented fractures) have similar plotted patterns, an increase of fractures leading to a fault structure and a drop in those fracture counts right before the structure. When a fault forms, deformation localizes in the fault core or fault structure. The surrounding area is the damage zone, consisting of fault-related structures and fractures, has an increase of structure density leading up to the core. Since deformation localizes within the fault core or structure, the surrounding adjacent area will have a "shadow" or a drop in fracture density, since it is rheologically easier to deform within the fault structure than next to it. The similarities between the plot that shows the density for all fractures 
vs. NS/EW striking fractures indicates that there are fault structures along the Dosewallips river particularly at outcrops 14.2 and 13.7 (Figure 8.3 and Figure 8.4).

Throughout the transect fracture density scales, outcrop 13.7 shows different fracture density patterns from outcrop 14.2. It has consistently higher counts, shows a greater variability in the range of counts at each subsection, and the fracture counts for the NS and EW trending fractures are less than the total fractures. This indicates that the fractures counted at 13.7 pick up the NS and EW trending fractures signal similar to those in 14.2 as well as additional fracture trends, likely linked to the array of fracture orientations in the strike and dip data. This may be the result of the rheological difference between outcrop 14.2 and 13.7. Outcrop 14.2 contains Blue Mountain Unit turbiditic and pyroclastic volcanics whereas the Crescent Fm. is pillow basalts in outcrop 13.7. Given this difference, the Crescent Fm. is more competent and more likely to deform by fracturing. The presence of shear structures within outcrop 14.2 (i.e., interlayering veins with host rock and fault core) and lack of these in 13.7 may support this interpretation. Outcrop 11.8 is also within the Crescent Fm. and has a similar fracture density count to outcrop 14.2. This difference between outcrops 13.7 and 11.8 is likely the result of 13.7 being affected by fault damage in a way that 11.8 is not. However, there are higher fracture counts for the in-situ per meter data at outcrop 14.2 when compared with the SfM derived data. The in-situ data counts fractures from a greater range of scales not seen in the SfM data, which are limited to the mesoscale to hand sample scale by the resolution of the photos. The implications of this are that both in-situ and SfM can pick up different levels of detail in fractured 
rock and that the fractures related to a fault's damage zone may not be picked up in the resolution of SfM.

All the structures along the transect show that there are differences in fracture orientation, fracture density, and structures when there is a fault structure present. The only identified fault core along the Dosewallips transect is in outcrop 14.2, and given the progression of comminution (i.e., cataclasite, fractures, gouge) leading to a matrix supported clastic rock with fluid alteration within and around the core area, I propose that this is a well-developed lithospheric fault (Ori fault; Figure 8.6C). At this location there is a contact between rock units of different competency, making the area a setting ideal for strain localization and formation of a fault core. On the contrary, outcrop 13.7 is an independent fault structure that is not as well-developed nor an extension of the Ori fault. Although this outcrop has a progression in comminution via how the rock fractures around pillows, there is no exposed fault core. The main evidence of fault deformation relies on localized cataclasite and pseudotachylyte veins, figure $8.6 \mathrm{C}$. This is also supported by the fracture density data showing an increase then drop in fracture density leading up to the fault structure that is not a continuation of the outcrop 14.2 data. This could also explain the difference in fracture density for outcrop 11.8 compared to the rest of the transect, where this outcrop 11.8 is not effected by a local fault structure and likely displays structures related to background deformation.

The presence of two fault structures at the base and within the Crescent Fm. shows that the Crescent Fm. along the eastern side of the peninsula is more deformed 
than previously described. The confirmation of cataclasite and pseudotachylyte show that faults within the Siletzia terrane were once seismically active. If outcrop 13.7 represents a lithospheric fault structure within the Crescent Fm., then accretionary faulting would have occurred within the rheologically stronger basalt unit. This conclusion is consistent with folding at the contact between the Upper and Lower Crescent Fm. as seen on the geologic map (Gerstel \& Lingley, 2003) and with the proposed structural contact between the Upper and Lower Crescent Fm. as described in the geochemical work of Babcock et al., (1992) and Hirsch and Babcock (2009). The findings from this study build a more detailed sketch of the Olympic Mountain accretionary complex, figure 8.6B. 


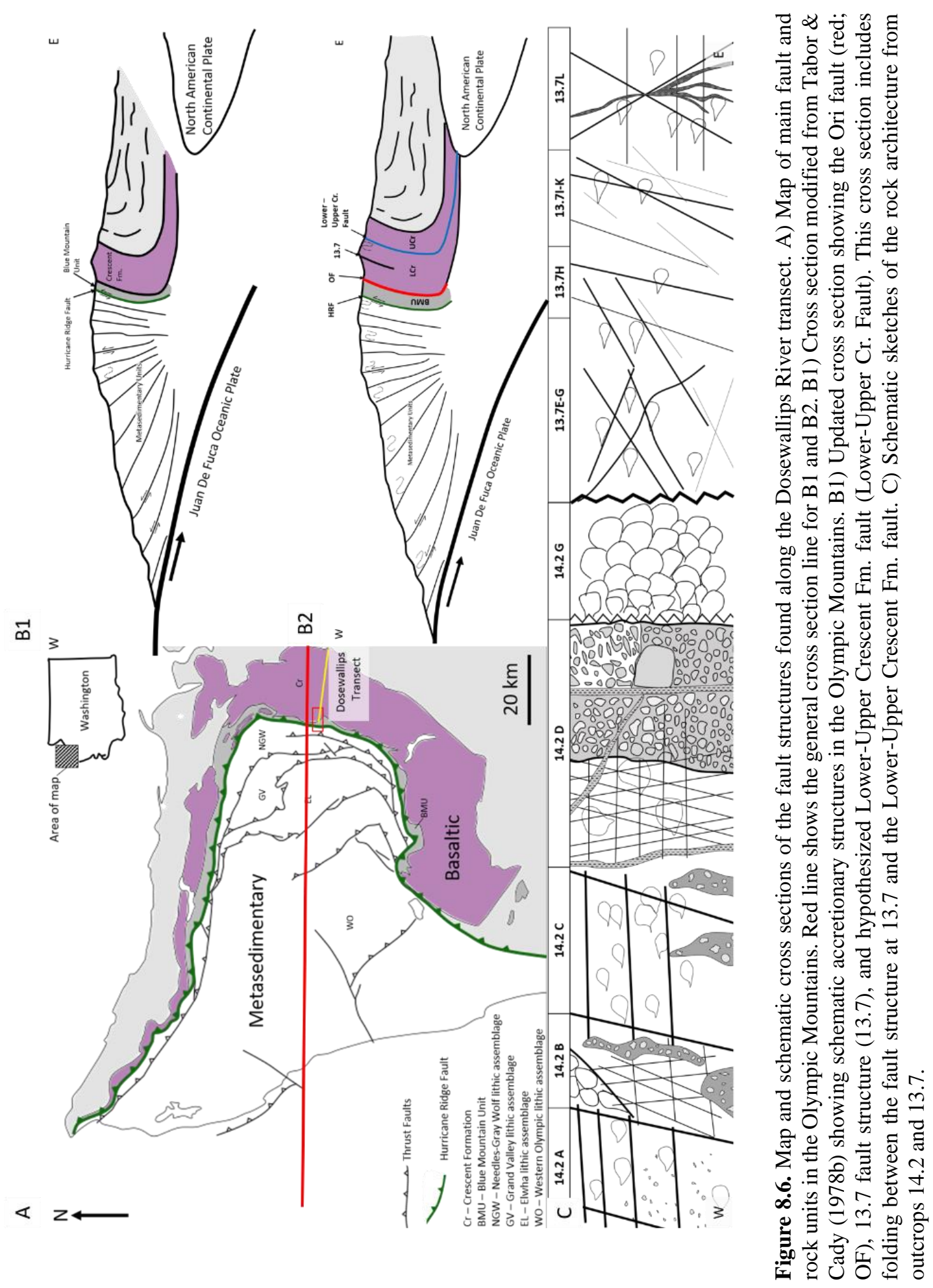




\section{Regional Implications and Conclusions}

This study focuses on the Dosewallips River Transect and characterizes the fault-related deformation along the metasedimentary-BMU-Crescent Fm. contacts. Eddy et al., 2017 collected geochronological data from the Dungeness and Lake Cushman transects, figure 9.1, and their data implies a fault at these sites. The location of the Ori fault at outcrop 14.2 is ideal for the presumed fault between the Blue Mountain Unit (BMU) and Crescent Fm. as suggested by Eddy et al. (2017). Since the Dosewallips Transect is between Dungeness and Lake Cushman transects, the Ori fault could extend to the SE to the NE portions of the peninsula (i.e., red fault outline in Figure 9.1). However, we cannot be sure of the southward extend of the Ori fault to the Dungeness and Lack Cushman transects without supported evidence. Currently, there are no studies of fault structures at these transects to correlate with the Ori fault.

Eddy et al. (2017) proposes that the Lower Elwha Fault (LEF), Crescent Fault (CF), and Lake Creek - Boundary Creek (LBR) faults (see Figure 9.1) may be an extension of the fault at the BMU-Crescent Fm. contact, the Ori fault, imbricating the BMU and associated volcanics under the Crescent Fm. This implies that if the location of the Ori fault is consistent throughout the Olympic Peninsula, then it is subparallel to the Hurricane Ridge Fault, has similar over steepened orientations, and follows the horseshoe map pattern. This also implies that there may be additional fault structures at the boundary with and within the Crescent Fm. This is evident in the presence of the once seismically active fault structure at outcrop 13.7 located approximately $1.6 \mathrm{~km}$ east of the Ori fault location at the BMU-Crescent Fm. 


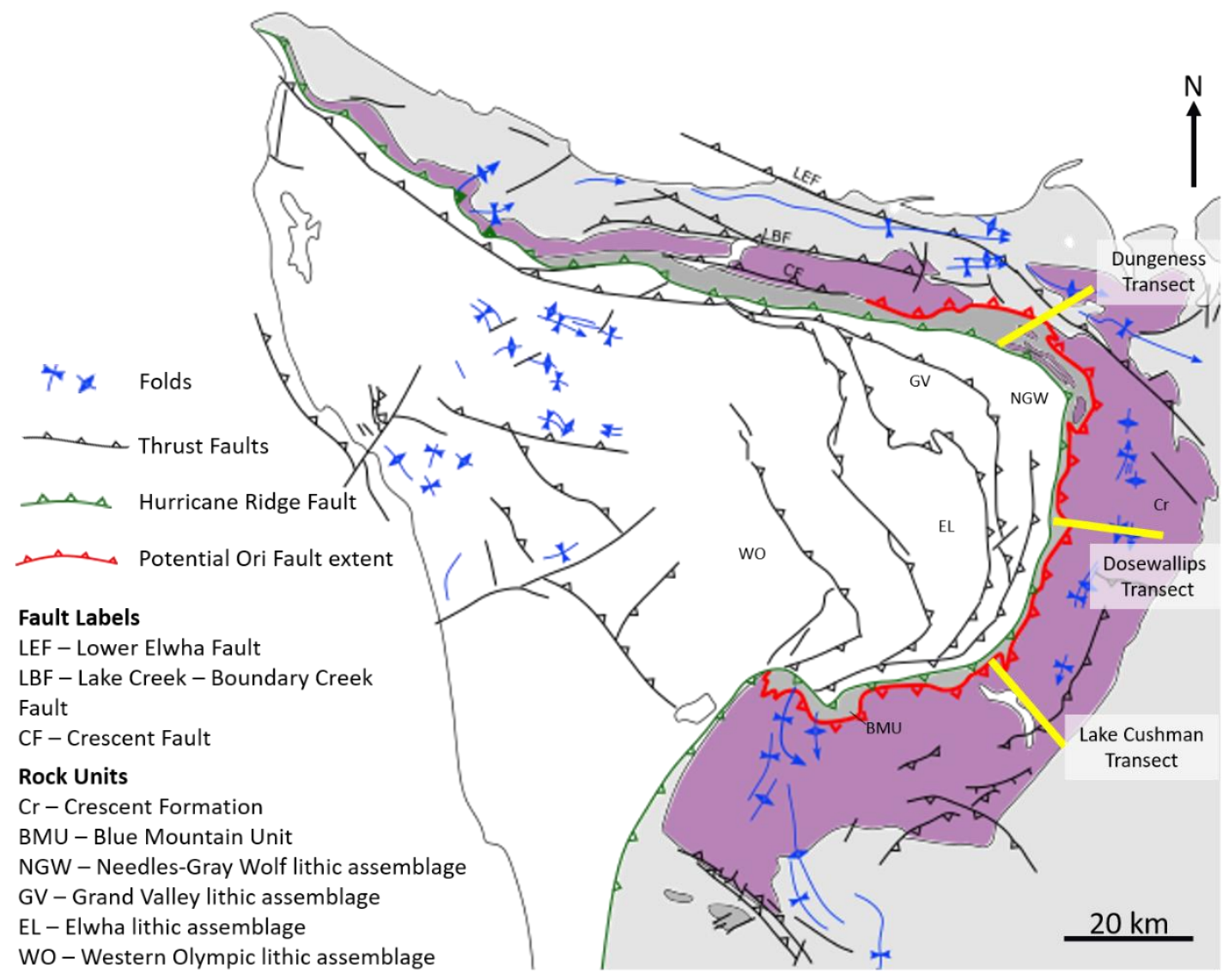

Figure 9.1. Updated structural map of the Olympic Mountains with documented faults and folds. The potential extent of the Ori fault is outlined in red. The three transects with data supporting the presence of the Ori fault are highlighted in yellow and labeled.

Rocks along this transect resided at the boundary between the prehnitepumpellyite and greenschist facies. There are no clear metamorphic discontinuities that would indicate structural juxtaposition of rocks from different depth levels. Therefore, the pressure and temperature regimes suggest that the faults formed at depth during accretion and have since uplifted. 
Overall, this study changes the deformation history of the Olympic Mountains and the accretion of Siletzia, as originally outlined by Tabor and Cady (1978b) (Figure 2.1). This history relies on the interfingering between the Crescent Fm. and metasedimentary units and describes the Crescent Fm. as a structural backstop and presents thrust faulting as concentrated in the metasedimentary core. This study and the evidence from Eddy et al. (2017) suggests that the development of the Olympic Mountains involved faulting between the Crescent Fm. and BMU and within the Crescent Fm. If this is the case, Siletzia was affected internally by accretion-related deformation.

Meso and microscale observations indicate a relationship between fault deformation and fluid infiltration. Cross-cutting evidence reveals that fluids entered the system after the fault formed. This is apparent in the veins containing rounded clasts of host rock, areas of hydrothermally-altered rock in contact with non-altered rock, and veins cross-cutting the fault core. Other veins that interlayer with the host rock, contain cataclasite, and have a mineral assemblage that suggests fault deformation continued at depth after fluids entered the system. Further research into these processes could reveal more about the fluid infiltration characteristics as they relate to accretionary subduction.

In order to solidify this study's claims, additional work is required throughout the Olympic Mountains' peripheral rocks. Similar methods applied to other transects that cross the BMU-Crescent Fm. contacts (i.e., Lack Cushman, Hamma Hamma, and Dungeness transects) would reveal structures that would support or refute the regional 
extent of the Ori fault. As well as additional research on the fault-related characteristics of the Hurricane Ridge Fault compared to the Ori fault. 


\section{References}

Allmendinger, R. W. (2018). Stereonet 10.

Allmendinger, R. W., Cardozo, N. C., \& Fisher, D. (2013). Structural Geology Algorithms: Vectors \& Tensors. Cambridge, England: Cambridge University Press.

Anderson, E. M. (1951). Dynamics of faulting and dyke formation with application to Britain. Oliver and Boyd.

Avolio, G. W. (1973). Granulometric analysis of recent sediments of Tillamook Bay, Oregon. Portland State University.

Babcock, R. S., Burmester, R. F., Engebretson, D. C., Warnock, A., \& Clark, K. P. (1992). A rifted margin origin for the crescent basalts and related rocks in the northern Coast Range Volcanic Province, Washington and British Columbia. Journal of Geophysical Research, 97(B5), 6799. https://doi.org/10.1029/91JB02926

Babcock, R. S., Suczek, C. A., \& Engebretson, D. C. (1994). The Crescent "Terrane", Olympic Peninsula and Southern Vancouver Island. Washinton Division of GEology and Earth REsources Bulletin, 80, 141-157.

Batt, E., Brandon, T., Farley, K. A., \& Roden-tice, M. (2001). Tectonic synthesis of the Olympic Mountains segment of the Cascadia wedge, using two-dimensional thermal and kinematic modeling of therrnochronological ages / $\mathrm{t}, 106$.

Billi, A., Salvini, F., \& Storti, F. (2003). The damage zone-fault core transition in carbonate rocks: Implications for fault growth, structure and permeability. Journal of Structural Geology, 25(11), 1779-1794. https://doi.org/10.1016/S0191-8141(03)00037-3

Cardozo, N., \& Allmendinger, R. W. (2013). Spherical projections with OSXStereonet. Computers and Geosciences, 51, 193-205. https://doi.org/10.1016/j.cageo.2012.07.021

Choi, J. H., Edwards, P., Ko, K., \& Kim, Y. S. (2016). Definition and classification of fault damage zones: A review and a new methodological approach. Earth-Science Reviews, 152(November 2015), 70-87. https://doi.org/10.1016/j.earscirev.2015.11.006

Duncan, R. (1982). A Captured Island Chain in the Coast Range of Oregon and Washington. Journal of Geophysical Research, 87(B13).

Eddy, M. P., Clark, K. P., \& Polenz, M. (2017). Age and volcanic stratigraphy of the Eocene Siletzia oceanic plateau in Washington and on Vancouver Island, (4), 113. https://doi.org/10.1130/L650.1

Einarsen, J. M. (1987). The Petrography and Tectonic Significance of the Blue 
Mountain Unit, Olympic Peninsula, Washington. Western Washington University.

Gerstel, W., \& Lingley, W. (2003). WASHINGTON DIVISION OF GEOLOGY AND EARTH RESOURCES Geologic Map of the Mount Olympus 1: 100, 000 Quadrangle, Washington. Washington Geologic Survey.

Handy, M., Hirth, G., \& Burgmann, R. (2007). Continental Fault Structure and Rheology from the Frictional-to-Viscous Transition Downward.

Handy, M., Hirth, G., \& Bürgmann, R. (2007). Continental fault structure and rheology from the frictional-to-viscous transition downward. Tectonic Faults: Agents of Change on A Dynamic Earth.

Hirsch, D. M., \& Babcock, R. S. (2009). Spatially heterogeneous burial and high-P/T metamorphism in the crescent formation, Olympic Peninsula, Washington. American Mineralogist, 94(8-9), 1103-1110. https://doi.org/10.2138/am.2009.3187

Jackson, M. K. (1983). Stratigraphic relationships of the Tillamook Volcanics and the Cowlitz Formation in the upper Nehalem River-Wolf Creek area, northwestern Oregon. Portland State University.

Kim, Y. S., Peacock, D. C. P., \& Sanderson, D. J. (2004). Fault damage zones. Journal of Structural Geology, 26(3), 503-517. https://doi.org/10.1016/j.jsg.2003.08.002

Kokelaar, P., \& Busby, C. (1992). Subaqueous explosive eruption and welding of pyroclastic deposits. Science, 257(5067), 196-201. https://doi.org/10.1126/science.257.5067.196

Lin, A. (2008). Fossil Earthquakes: The Formation and Preservation of Pseudotachylytes. New York: Springer Berlin Heidelberg.

Mittempergher, S., Pennacchioni, G., \& Di Toro, G. (2009). The effects of fault orientation and fluid infiltration on fault rock assemblages at seismogenic depths. Journal of Structural Geology, 31(12), 1511-1524. https://doi.org/10.1016/j.jsg.2009.09.003

Parsons, T., Wells, R. E., Fisher, M. a., Flueh, E., \& ten Brink, U. S. (1999). Threedimensional velocity structure of Siletzia and other accreted terranes in the Cascadia forearc of Washington. Journal of Geophysical Research, 104(B8), 18015-18039. https://doi.org/10.1029/1999JB900106

Passchier, C. W., \& Trouw, R. A. (2005). Microtectonics. Berlin: Springer.

Price, N. A., Johnson, S. E., Gerbi, C. C., \& Jr, D. P. W. (2012). Identifying deformed pseudotachylyte and its in fl uence on the strength and evolution of a crustal shear zone at the base of the seismogenic zone. Tectonophysics, 518-521, 63-83. https://doi.org/10.1016/j.tecto.2011.11.011 
Schmandt, B., \& Humphreys, E. (2011). Seismically imaged relict slab from the 55 Ma Siletzia accretion to the northwest United States. Geology, 39(2), 175-178. https://doi.org/10.1130/G31558.1

Stipp, M., Stünitz, H., Heilbronner, R., \& Schmid, S. M. (2002). The eastern Tonale fault zone: A "natural laboratory" for crystal plastic deformation of quartz over a temperature range from 250 to $700{ }^{\circ} \mathrm{C}$. Journal of Structural Geology, 24(12), 1861-1884. https://doi.org/10.1016/S0191-8141(02)00035-4

Tabor, R. W., \& Cady, W. M. (1978a), Geologic Map of the Olympic Peninsula, Washington, U.S. Geological Survey Miscellaneous Investigations Map I-994, 2 oversize sheets, scale 1:125,000.

Tabor, R. W., \& Cady, W. M. (1978b). The structure of the Olympic Mountains, Washington; analysis of a subduction zone. U. S. Geological Survey Professional Paper, 1033, 38.

Wells, R., Bukry, D., Friedman, R., Pyle, D., Duncan, R., Haeussler, P., \& Wooden, J. (2014). Geologic history of Siletzia, a large igneous province in the Oregon and Washington Coast Range: Correlation to the geomagnetic polarity time scale and implications for a long-lived Yellowstone hotspot. Geosphere, 10(4), 692-719. https://doi.org/10.1130/GES01018.1

Wells, R. E., \& McCaffrey, R. (2013). Steady rotation of the Cascade arc. Geology, 41(9), 1027-1030. https://doi.org/10.1130/G34514.1

Wells, R. E., Weaver, C. S., \& Blakely, R. J. (1998). Fore-arc migration in Cascadia and its neotectonic significance. Geology, 26(8), 759-762. https://doi.org/10.1130/0091-7613(1998)026<0759:FAMICA>2.3.CO;2

Winter, J. D. (2010). Principles of Igneous and Metamorphic Petrology (2nd ed.). Upper Saddle River: Pearson Education Inc. 


\section{Appendix A - Outcrop Boundary GPS Coordinates}

Table A1. Outcrop boundary GPS coordinates.

\begin{tabular}{|l|r|}
\hline Outcrop & GPS Boundaries \\
\hline 15.1 & 47.74263 \\
& -123.17577 \\
\hline 14.9 & 47.74263 \\
& -123.17864 \\
\hline 14.2 - West end & 47.73711 \\
& -123.16025 \\
\hline 14.2 - East end & 47.7366 \\
\hline 13.7 - West end & -123.16025 \\
\hline 13.7 - East end & 47.73193 \\
& -123.15011 \\
\hline 11.8 - West end & 47.73035 \\
\hline 11.8 - East end & -123.4866 \\
\hline
\end{tabular}




\section{Appendix B - Strike and Dip Data}

Table B1. Fracture orientation data for outcrop 14.2

\begin{tabular}{|c|c|c|c|c|c|c|c|c|c|c|c|}
\hline Site & Strike & dip & Site & Strike & dip & Site & Strike & dip & Site & Strike & dip \\
\hline $14.2 \mathrm{~A}$ & 215 & 90 & $14.2 \mathrm{~A}$ & 211 & 89 & $14.2 \mathrm{~B}-\mathrm{C}$ & 226 & 32 & $14.2 \mathrm{D}$ & 196 & 26 \\
\hline $14.2 \mathrm{~A}$ & 270 & 50 & $14.2 \mathrm{~A}$ & 255 & 23 & $14.2 \mathrm{~B}-\mathrm{C}$ & 206 & 75 & $14.2 \mathrm{D}$ & 204 & 57 \\
\hline $14.2 \mathrm{~A}$ & 271 & 58 & $14.2 \mathrm{~A}$ & 200 & 65 & $14.2 \mathrm{~B}-\mathrm{C}$ & 221 & 46 & $14.2 \mathrm{D}$ & 220 & 72 \\
\hline $14.2 \mathrm{~A}$ & 210 & 84 & $14.2 \mathrm{~A}$ & 240 & 37 & $14.2 \mathrm{~B}-\mathrm{C}$ & 200 & 40 & $14.2 \mathrm{D}$ & 209 & 72 \\
\hline $14.2 \mathrm{~A}$ & 240 & 60 & $14.2 \mathrm{~A}$ & 219 & 21 & $14.2 \mathrm{~B}-\mathrm{C}$ & 191 & 27 & $14.2 \mathrm{D}$ & 176 & 30 \\
\hline $14.2 \mathrm{~A}$ & 255 & 30 & $14.2 \mathrm{~A}$ & 254 & 40 & $14.2 \mathrm{~B}-\mathrm{C}$ & 190 & 86 & $14.2 \mathrm{D}$ & 211 & 89 \\
\hline $14.2 \mathrm{~A}$ & 225 & 25 & $14.2 \mathrm{~A}$ & 256 & 22 & $14.2 \mathrm{~B}-\mathrm{C}$ & 212 & 21 & $14.2 \mathrm{D}$ & 176 & 48 \\
\hline $14.2 \mathrm{~A}$ & 240 & 60 & $14.2 \mathrm{~A}$ & 208 & 83 & $14.2 \mathrm{~B}-\mathrm{C}$ & 217 & 30 & $14.2 \mathrm{D}$ & 209 & 84 \\
\hline $14.2 \mathrm{~A}$ & 233 & 66 & $14.2 \mathrm{~A}$ & 264 & 26 & $14.2 \mathrm{~B}-\mathrm{C}$ & 30 & 60 & $14.2 \mathrm{D}$ & 296 & 44 \\
\hline $14.2 \mathrm{~A}$ & 195 & 72 & $14.2 \mathrm{~A}$ & 254 & 24 & $14.2 \mathrm{~B}-\mathrm{C}$ & 223 & 20 & $14.2 \mathrm{D}$ & 188 & 36 \\
\hline $14.2 \mathrm{~A}$ & 169 & 61 & $14.2 \mathrm{~A}$ & 116 & 89 & $14.2 \mathrm{D}$ & 230 & 36 & $14.2 \mathrm{D}$ & 192 & 50 \\
\hline $14.2 \mathrm{~A}$ & 233 & 56 & $14.2 \mathrm{~A}$ & 224 & 63 & $14.2 \mathrm{D}$ & 166 & 35 & $14.2 \mathrm{D}$ & 174 & 67 \\
\hline $14.2 \mathrm{~A}$ & 233 & 25 & $14.2 \mathrm{~A}$ & 113 & 85 & $14.2 \mathrm{D}$ & 314 & 12 & $14.2 \mathrm{D}$ & 190 & 72 \\
\hline $14.2 \mathrm{~A}$ & 38 & 69 & $14.2 \mathrm{~A}$ & 17 & 65 & $14.2 \mathrm{D}$ & 187 & 27 & $14.2 \mathrm{D}$ & 172 & 69 \\
\hline $14.2 \mathrm{~A}$ & 224 & 71 & $14.2 \mathrm{~A}$ & 170 & 72 & 14.2 D & 214 & 86 & $14.2 \mathrm{D}$ & 182 & 32 \\
\hline $14.2 \mathrm{~A}$ & 19 & 0 & $14.2 \mathrm{~A}$ & 74 & 45 & $14.2 \mathrm{D}$ & 33 & 65 & $14.2 \mathrm{D}$ & 223 & 33 \\
\hline $14.2 \mathrm{~A}$ & 266 & 36 & $14.2 \mathrm{~B}-\mathrm{C}$ & 213 & 16 & $14.2 \mathrm{D}$ & 264 & 25 & $14.2 \mathrm{G}$ & 221 & 20 \\
\hline $14.2 \mathrm{~A}$ & 193 & 50 & 14.2 B-C & 223 & 48 & $14.2 \mathrm{D}$ & 207 & 63 & $14.2 \mathrm{G}$ & 202 & 20 \\
\hline $14.2 \mathrm{~A}$ & 210 & 82 & $14.2 \mathrm{~B}-\mathrm{C}$ & 209 & 56 & $14.2 \mathrm{D}$ & 206 & 20 & $14.2 \mathrm{G}$ & 130 & 7 \\
\hline $14.2 \mathrm{~A}$ & 174 & 56 & 14.2 B-C & 209 & 90 & $14.2 \mathrm{D}$ & 189 & 20 & $14.2 \mathrm{G}$ & 208 & 54 \\
\hline $14.2 \mathrm{~A}$ & 260 & 30 & 14.2 B-C & 200 & 46 & $14.2 \mathrm{D}$ & 174 & 30 & $14.2 \mathrm{G}$ & 210 & 80 \\
\hline $14.2 \mathrm{~A}$ & 190 & 51 & 14.2 B-C & 210 & 57 & $14.2 \mathrm{D}$ & 174 & 49 & $14.2 \mathrm{G}$ & 167 & 26 \\
\hline $14.2 \mathrm{~A}$ & 94 & 90 & 14.2 B-C & 115 & 84 & $14.2 \mathrm{D}$ & 340 & 34 & $14.2 \mathrm{G}$ & 156 & 40 \\
\hline $14.2 \mathrm{~A}$ & 301 & 80 & $14.2 \mathrm{~B}-\mathrm{C}$ & 232 & 24 & $14.2 \mathrm{D}$ & 200 & 25 & $14.2 \mathrm{G}$ & 175 & 45 \\
\hline $14.2 \mathrm{~A}$ & 121 & 82 & 14.2 B-C & 213 & 64 & $14.2 \mathrm{D}$ & 190 & 25 & $14.2 \mathrm{G}$ & 209 & 21 \\
\hline $14.2 \mathrm{~A}$ & 10 & 74 & $14.2 \mathrm{~B}-\mathrm{C}$ & 207 & 65 & $14.2 \mathrm{D}$ & 189 & 70 & $14.2 \mathrm{G}$ & 151 & 56 \\
\hline $14.2 \mathrm{~A}$ & 154 & 64 & 14.2 B-C & 266 & 25 & $14.2 \mathrm{D}$ & 330 & 40 & $14.2 \mathrm{G}$ & 320 & 30 \\
\hline $14.2 \mathrm{~A}$ & 299 & 75 & $14.2 \mathrm{~B}-\mathrm{C}$ & 210 & 65 & $14.2 \mathrm{D}$ & 110 & 77 & $14.2 \mathrm{G}$ & 303 & 65 \\
\hline $14.2 \mathrm{~A}$ & 200 & 76 & $14.2 \mathrm{~B}-\mathrm{C}$ & 225 & 42 & $14.2 \mathrm{D}$ & 216 & 80 & $14.2 \mathrm{G}$ & 178 & 25 \\
\hline $14.2 \mathrm{~A}$ & 254 & 21 & 14.2 B-C & 206 & 4 & $14.2 \mathrm{D}$ & 205 & 81 & $14.2 \mathrm{G}$ & 26 & 44 \\
\hline $14.2 \mathrm{~A}$ & 190 & 80 & 14.2 B-C & 249 & 60 & $14.2 \mathrm{D}$ & 186 & 62 & $14.2 \mathrm{G}$ & 10 & 54 \\
\hline $14.2 \mathrm{~A}$ & 223 & 90 & 14.2 B-C & 215 & 55 & $14.2 \mathrm{D}$ & 197 & 66 & $14.2 \mathrm{G}$ & 332 & 73 \\
\hline $14.2 \mathrm{~A}$ & 235 & 83 & 14.2 B-C & 200 & 64 & $14.2 \mathrm{D}$ & 194 & 22 & $14.2 \mathrm{G}$ & 312 & 21 \\
\hline $14.2 \mathrm{~A}$ & 206 & 81 & 14.2 B-C & 196 & 80 & $14.2 \mathrm{D}$ & 199 & 67 & $14.2 \mathrm{G}$ & 151 & 88 \\
\hline $14.2 \mathrm{~A}$ & 250 & 27 & $14.2 \mathrm{~B}-\mathrm{C}$ & 276 & 1 & $14.2 \mathrm{D}$ & 194 & 72 & $14.2 \mathrm{G}$ & 282 & 85 \\
\hline $14.2 \mathrm{~A}$ & 185 & 84 & $14.2 \mathrm{~B}-\mathrm{C}$ & 303 & 81 & $14.2 \mathrm{D}$ & 203 & 22 & & & \\
\hline $14.2 \mathrm{~A}$ & 280 & 13 & 14.2 B-C & 250 & 30 & $14.2 \mathrm{D}$ & 203 & 21 & & & \\
\hline
\end{tabular}


Table B2. Fracture orientations from outcrop 13.7.

\begin{tabular}{|c|c|c|c|c|c|c|c|c|c|c|c|}
\hline Site & Strike & dip & Site & Strike & dip & Site & Strike & dip & Site & Strike & dip \\
\hline $13.7 \mathrm{~L}$ & 295 & 60 & $13.7 \mathrm{I}-\mathrm{K}$ & 100 & 43 & $13.7 \mathrm{H}$ & 195 & 87 & 13.7 F-G & 14 & 63 \\
\hline $13.7 \mathrm{~L}$ & 9 & 90 & $13.7 \mathrm{I}-\mathrm{K}$ & 27 & 25 & $13.7 \mathrm{H}$ & 199 & 40 & 13.7 F-G & 105 & 83 \\
\hline $13.7 \mathrm{~L}$ & 299 & 44 & 13.7 I-K & 15 & 34 & $13.7 \mathrm{H}$ & 178 & 49 & 13.7 F-G & 154 & 84 \\
\hline $13.7 \mathrm{~L}$ & 53 & 40 & $13.7 \mathrm{I}-\mathrm{K}$ & 272 & 64 & $13.7 \mathrm{H}$ & 190 & 61 & 13.7 F-G & 112 & 83 \\
\hline $13.7 \mathrm{~L}$ & 320 & 64 & $13.7 \mathrm{I}-\mathrm{K}$ & 101 & 88 & $13.7 \mathrm{H}$ & 219 & 31 & 13.7 F-G & 249 & 50 \\
\hline $13.7 \mathrm{~L}$ & 192 & 41 & 13.7 I-K & 305 & 79 & $13.7 \mathrm{H}$ & 320 & 15 & 13.7 F-G & 32 & 55 \\
\hline $13.7 \mathrm{~L}$ & 195 & 39 & 13.7 I-K & 221 & 34 & $13.7 \mathrm{H}$ & 198 & 68 & 13.7 F-G & 214 & 79 \\
\hline $13.7 \mathrm{~L}$ & 221 & 27 & 13.7 I-K & 236 & 17 & $13.7 \mathrm{H}$ & 169 & 61 & 13.7 F-G & 206 & 60 \\
\hline $13.7 \mathrm{~L}$ & 0 & 45 & $13.7 \mathrm{I}-\mathrm{K}$ & 350 & 60 & $13.7 \mathrm{H}$ & 285 & 26 & 13.7 F-G & 254 & 43 \\
\hline $13.7 \mathrm{~L}$ & 346 & 50 & 13.7 I-K & 303 & 72 & $13.7 \mathrm{H}$ & 213 & 75 & 13.7 F-G & 185 & 90 \\
\hline $13.7 \mathrm{~L}$ & 195 & 38 & 13.7 I-K & 295 & 66 & $13.7 \mathrm{H}$ & 87 & 51 & 13.7 F-G & 217 & 70 \\
\hline $13.7 \mathrm{~L}$ & 370 & 90 & $13.7 \mathrm{I}-\mathrm{K}$ & 344 & 75 & $13.7 \mathrm{H}$ & 250 & 40 & 13.7 F-G & 350 & 80 \\
\hline $13.7 \mathrm{~L}$ & 13 & 81 & 13.7 I-K & 35 & 53 & $13.7 \mathrm{H}$ & 57 & 59 & 13.7 F-G & 194 & 86 \\
\hline $13.7 \mathrm{~L}$ & 190 & 37 & $13.7 \mathrm{I}-\mathrm{K}$ & 205 & 36 & $13.7 \mathrm{H}$ & 10 & 45 & 13.7 F-G & 183 & 80 \\
\hline $13.7 \mathrm{~L}$ & 287 & 70 & 13.7 I-K & 305 & 40 & $13.7 \mathrm{H}$ & 188 & 57 & 13.7 F-G & 85 & 65 \\
\hline $13.7 \mathrm{~L}$ & 334 & 46 & $13.7 \mathrm{I}-\mathrm{K}$ & 8 & 39 & $13.7 \mathrm{H}$ & 6 & 59 & 13.7 F-G & 190 & 77 \\
\hline $13.7 \mathrm{~L}$ & 292 & 64 & $13.7 \mathrm{I}-\mathrm{K}$ & 191 & 19 & $13.7 \mathrm{H}$ & 183 & 54 & $13.7 \mathrm{E}$ & 211 & 64 \\
\hline $13.7 \mathrm{~L}$ & 291 & 81 & $13.7 \mathrm{I}-\mathrm{K}$ & 12 & 50 & $13.7 \mathrm{H}$ & 187 & 51 & $13.7 \mathrm{E}$ & 82 & 62 \\
\hline $13.7 \mathrm{~L}$ & 185 & 29 & $13.7 \mathrm{I}-\mathrm{K}$ & 204 & 63 & $13.7 \mathrm{H}$ & 148 & 49 & $13.7 \mathrm{E}$ & 305 & 90 \\
\hline $13.7 \mathrm{~L}$ & 135 & 84 & $13.7 \mathrm{I}-\mathrm{K}$ & 20 & 15 & $13.7 \mathrm{H}$ & 184 & 37 & $13.7 \mathrm{E}$ & 241 & 44 \\
\hline $13.7 \mathrm{~L}$ & 296 & 65 & $13.7 \mathrm{I}-\mathrm{K}$ & 0 & 73 & $13.7 \mathrm{H}$ & 35 & 45 & $13.7 \mathrm{E}$ & 230 & 50 \\
\hline $13.7 \mathrm{~L}$ & 294 & 86 & $13.7 \mathrm{I}-\mathrm{K}$ & 339 & 36 & $13.7 \mathrm{H}$ & 274 & 90 & $13.7 \mathrm{E}$ & 309 & 45 \\
\hline $13.7 \mathrm{~L}$ & 14 & 52 & $13.7 \mathrm{I}-\mathrm{K}$ & 340 & 41 & $13.7 \mathrm{H}$ & 186 & 50 & $13.7 \mathrm{E}$ & 233 & 46 \\
\hline $13.7 \mathrm{~L}$ & 90 & 84 & 13.7 I-K & 20 & 85 & $13.7 \mathrm{H}$ & 33 & 58 & $13.7 \mathrm{E}$ & 312 & 78 \\
\hline $13.7 \mathrm{~L}$ & 20 & 45 & 13.7 I-K & 213 & 66 & $13.7 \mathrm{H}$ & 181 & 82 & $13.7 \mathrm{E}$ & 205 & 62 \\
\hline $13.7 \mathrm{~L}$ & 28 & 46 & 13.7 I-K & 7 & 54 & 13.7 F-G & 274 & 78 & $13.7 \mathrm{E}$ & 255 & 30 \\
\hline $13.7 \mathrm{~L}$ & 331 & 79 & $13.7 \mathrm{I}-\mathrm{K}$ & 215 & 35 & 13.7 F-G & 60 & 32 & $13.7 \mathrm{E}$ & 237 & 46 \\
\hline $13.7 \mathrm{~L}$ & 188 & 88 & $13.7 \mathrm{I}-\mathrm{K}$ & 212 & 42 & 13.7 F-G & 296 & 70 & $13.7 \mathrm{E}$ & 88 & 76 \\
\hline $13.7 \mathrm{~L}$ & 189 & 90 & 13.7 I-K & 351 & 60 & 13.7 F-G & 247 & 49 & $13.7 \mathrm{E}$ & 231 & 44 \\
\hline $13.7 \mathrm{I}-\mathrm{K}$ & 281 & 59 & $13.7 \mathrm{I}-\mathrm{K}$ & 216 & 54 & 13.7 F-G & 340 & 59 & $13.7 \mathrm{E}$ & 10 & 49 \\
\hline $13.7 \mathrm{I}-\mathrm{K}$ & 128 & 40 & $13.7 \mathrm{I}-\mathrm{K}$ & 7 & 58 & 13.7 F-G & 273 & 66 & $13.7 \mathrm{E}$ & 80 & 65 \\
\hline $13.7 \mathrm{I}-\mathrm{K}$ & 3 & 80 & $13.7 \mathrm{I}-\mathrm{K}$ & 9 & 76 & $13.7 \mathrm{~F}-\mathrm{G}$ & 282 & 67 & $13.7 \mathrm{E}$ & 227 & 56 \\
\hline $13.7 \mathrm{I}-\mathrm{K}$ & 35 & 51 & 13.7 I-K & 225 & 48 & 13.7 F-G & 194 & 89 & $13.7 \mathrm{E}$ & 50 & 79 \\
\hline 13.7 I-K & 350 & 25 & $13.7 \mathrm{I}-\mathrm{K}$ & 11 & 53 & 13.7 F-G & 166 & 57 & & & \\
\hline $13.7 \mathrm{I}-\mathrm{K}$ & 1 & 47 & 13.7 I-K & 354 & 69 & 13.7 F-G & 159 & 80 & & & \\
\hline $13.7 \mathrm{I}-\mathrm{K}$ & 230 & 74 & $13.7 \mathrm{I}-\mathrm{K}$ & 5 & 78 & 13.7 F-G & 187 & 76 & & & \\
\hline
\end{tabular}


Table B3. Fracture Orientations for outcrop 11.8.

\begin{tabular}{|c|c|c|c|c|c|c|c|c|c|c|c|}
\hline Site & Strike & dip & Site & Strike & dip & Site & Strike & dip & Site & Strike & dip \\
\hline $11.8 \mathrm{~A}$ & 340 & 90 & $11.8 \mathrm{C}$ & 236 & 61 & $11.8 \mathrm{E}$ & 300 & 50 & $11.8 \mathrm{G}$ & 205 & 50 \\
\hline $11.8 \mathrm{~A}$ & 35 & 77 & $11.8 \mathrm{C}$ & 30 & 72 & $11.8 \mathrm{E}$ & 266 & 50 & $11.8 \mathrm{G}$ & 205 & 52 \\
\hline $11.8 \mathrm{~A}$ & 336 & 85 & $11.8 \mathrm{C}$ & 236 & 54 & $11.8 \mathrm{E}$ & 142 & 58 & $11.8 \mathrm{G}$ & 16 & 35 \\
\hline $11.8 \mathrm{~A}$ & 284 & 70 & $11.8 \mathrm{C}$ & 86 & 40 & $11.8 \mathrm{E}$ & 225 & 36 & $11.8 \mathrm{G}$ & 196 & 44 \\
\hline $11.8 \mathrm{~A}$ & 212 & 75 & $11.8 \mathrm{C}$ & 236 & 61 & $11.8 \mathrm{E}$ & 190 & 44 & $11.8 \mathrm{G}$ & 283 & 85 \\
\hline $11.8 \mathrm{~A}$ & 111 & 74 & $11.8 \mathrm{C}$ & 3 & 72 & $11.8 \mathrm{E}$ & 290 & 70 & $11.8 \mathrm{G}$ & 243 & 40 \\
\hline $11.8 \mathrm{~A}$ & 185 & 35 & $11.8 \mathrm{C}$ & 236 & 54 & $11.8 \mathrm{E}$ & 195 & 70 & $11.8 \mathrm{G}$ & 183 & 27 \\
\hline $11.8 \mathrm{~A}$ & 20 & 69 & $11.8 \mathrm{C}$ & 265 & 40 & $11.8 \mathrm{E}$ & 280 & 80 & & & \\
\hline $11.8 \mathrm{~A}$ & 195 & 33 & $11.8 \mathrm{C}$ & 14 & 69 & $11.8 \mathrm{E}$ & 227 & 85 & & & \\
\hline $11.8 \mathrm{~A}$ & 200 & 89 & $11.8 \mathrm{C}$ & 35 & 46 & $11.8 \mathrm{E}$ & 249 & 33 & & & \\
\hline $11.8 \mathrm{~A}$ & 16 & 82 & $11.8 \mathrm{C}$ & 241 & 46 & $11.8 \mathrm{E}$ & 145 & 49 & & & \\
\hline $11.8 \mathrm{~A}$ & 205 & 77 & $11.8 \mathrm{C}$ & 218 & 51 & $11.8 \mathrm{E}$ & 34 & 90 & & & \\
\hline $11.8 \mathrm{~B}$ & 212 & 52 & $11.8 \mathrm{C}$ & 206 & 58 & $11.8 \mathrm{E}$ & 175 & 30 & & & \\
\hline $11.8 \mathrm{~B}$ & 227 & 40 & $11.8 \mathrm{C}$ & 217 & 76 & $11.8 \mathrm{E}$ & 202 & 22 & & & \\
\hline $11.8 \mathrm{~B}$ & 235 & 60 & $11.8 \mathrm{C}$ & 260 & 60 & $11.8 \mathrm{E}$ & 116 & 85 & & & \\
\hline $11.8 \mathrm{~B}$ & 244 & 67 & $11.8 \mathrm{C}$ & 224 & 57 & $11.8 \mathrm{~F}$ & 80 & 16 & & & \\
\hline $11.8 \mathrm{~B}$ & 37 & 78 & $11.8 \mathrm{C}$ & 225 & 60 & $11.8 \mathrm{~F}$ & 7 & 55 & & & \\
\hline $11.8 \mathrm{~B}$ & 218 & 55 & $11.8 \mathrm{C}$ & 250 & 70 & $11.8 \mathrm{~F}$ & 88 & 47 & & & \\
\hline $11.8 \mathrm{~B}$ & 203 & 46 & $11.8 \mathrm{C}$ & 235 & 60 & $11.8 \mathrm{~F}$ & 77 & 81 & & & \\
\hline $11.8 \mathrm{~B}$ & 210 & 35 & $11.8 \mathrm{C}$ & 217 & 55 & $11.8 \mathrm{~F}$ & 250 & 55 & & & \\
\hline $11.8 \mathrm{~B}$ & 215 & 30 & $11.8 \mathrm{C}$ & 347 & 35 & $11.8 \mathrm{~F}$ & 245 & 55 & & & \\
\hline $11.8 \mathrm{~B}$ & 229 & 34 & $11.8 \mathrm{D}$ & 249 & 55 & $11.8 \mathrm{~F}$ & 228 & 45 & & & \\
\hline $11.8 \mathrm{~B}$ & 205 & 48 & $11.8 \mathrm{D}$ & 250 & 52 & $11.8 \mathrm{~F}$ & 45 & 75 & & & \\
\hline $11.8 \mathrm{~B}$ & 323 & 42 & $11.8 \mathrm{D}$ & 0 & 43 & $11.8 \mathrm{~F}$ & 342 & 70 & & & \\
\hline $11.8 \mathrm{~B}$ & 187 & 46 & $11.8 \mathrm{D}$ & 178 & 54 & $11.8 \mathrm{~F}$ & 13 & 80 & & & \\
\hline $11.8 \mathrm{~B}$ & 199 & 47 & $11.8 \mathrm{D}$ & 174 & 61 & $11.8 \mathrm{~F}$ & 74 & 63 & & & \\
\hline $11.8 \mathrm{~B}$ & 322 & 72 & $11.8 \mathrm{D}$ & 254 & 42 & $11.8 \mathrm{~F}$ & 265 & 73 & & & \\
\hline $11.8 \mathrm{~B}$ & 225 & 45 & $11.8 \mathrm{D}$ & 269 & 44 & $11.8 \mathrm{~F}$ & 216 & 26 & & & \\
\hline $11.8 \mathrm{C}$ & 183 & 75 & $11.8 \mathrm{D}$ & 354 & 51 & $11.8 \mathrm{G}$ & 235 & 76 & & & \\
\hline $11.8 \mathrm{C}$ & 246 & 70 & $11.8 \mathrm{D}$ & 8 & 74 & $11.8 \mathrm{G}$ & 128 & 67 & & & \\
\hline $11.8 \mathrm{C}$ & 230 & 60 & $11.8 \mathrm{D}$ & 354 & 64 & $11.8 \mathrm{G}$ & 213 & 55 & & & \\
\hline $11.8 \mathrm{C}$ & 230 & 63 & $11.8 \mathrm{D}$ & 155 & 55 & $11.8 \mathrm{G}$ & 52 & 53 & & & \\
\hline $11.8 \mathrm{C}$ & 235 & 60 & $11.8 \mathrm{D}$ & 152 & 68 & $11.8 \mathrm{G}$ & 50 & 62 & & & \\
\hline $11.8 \mathrm{C}$ & 306 & 35 & $11.8 \mathrm{D}$ & 330 & 84 & $11.8 \mathrm{G}$ & 184 & 49 & & & \\
\hline $11.8 \mathrm{C}$ & 235 & 60 & $11.8 \mathrm{D}$ & 176 & 62 & $11.8 \mathrm{G}$ & 275 & 80 & & & \\
\hline $11.8 \mathrm{C}$ & 0 & 42 & $11.8 \mathrm{D}$ & 336 & 43 & $11.8 \mathrm{G}$ & 184 & 55 & & & \\
\hline $11.8 \mathrm{C}$ & 235 & 55 & $11.8 \mathrm{D}$ & 96 & 69 & $11.8 \mathrm{G}$ & 203 & 45 & & & \\
\hline $11.8 \mathrm{C}$ & 235 & 57 & $11.8 \mathrm{D}$ & 226 & 65 & $11.8 \mathrm{G}$ & 355 & 63 & & & \\
\hline $11.8 \mathrm{C}$ & 86 & 40 & $11.8 \mathrm{E}$ & 126 & 63 & $11.8 \mathrm{G}$ & 96 & 82 & & & \\
\hline
\end{tabular}


Table B4. Fracture orientations for outcrop 14.9 and 15.1.

\begin{tabular}{|l|r|r|l|r|r|}
\hline Site & Strike & dip & Site & Strike & dip \\
\hline 14.9 & 269 & 49 & 15.1 & 194 & 74 \\
\hline 14.9 & 260 & 59 & 15.1 & 304 & 85 \\
\hline 14.9 & 306 & 34 & 15.1 & 296 & 80 \\
\hline 14.9 & 255 & 60 & 15.1 & 195 & 78 \\
\hline 14.9 & 80 & 76 & 15.1 & 343 & 82 \\
\hline 14.9 & 260 & 26 & 15.1 & 95 & 39 \\
\hline 14.9 & 246 & 60 & 15.1 & 230 & 67 \\
\hline 14.9 & 230 & 49 & 15.1 & 198 & 79 \\
\hline 14.9 & 239 & 42 & 15.1 & 330 & 73 \\
\hline 14.9 & 41 & 43 & 15.1 & 270 & 40 \\
\hline 14.9 & 115 & 85 & 15.1 & 195 & 79 \\
\hline 14.9 & 91 & 90 & 15.1 & 357 & 14 \\
\hline 14.9 & 279 & 69 & 15.1 & 356 & 15 \\
\hline 14.9 & 278 & 74 & 15.1 & 185 & 90 \\
\hline 14.9 & 70 & 67 & 15.1 & 282 & 56 \\
\hline 14.9 & 294 & 51 & 15.1 & 77 & 20 \\
\hline 14.9 & 277 & 74 & 15.1 & 340 & 10 \\
\hline & & & 15.1 & 72 & 29 \\
\hline & & & 15.1 & 204 & 90 \\
\hline
\end{tabular}


Table B5. Bedding orientation data for outcrops 14.9 and 15.1.

\begin{tabular}{|l|l|l|l|l|l|}
\hline Site & Strike & Dip & Site & Strike & Dip \\
\hline 14.9 & 65 & 77 & 15.1 & 197 & 80 \\
\hline 14.9 & 70 & 83 & 15.1 & 197 & 81 \\
\hline 14.9 & 77 & 81 & 15.1 & 192 & 79 \\
\hline 14.9 & 51 & 51 & 15.1 & 181 & 78 \\
\hline 14.9 & 28 & 55 & 15.1 & 196 & 70 \\
\hline 14.9 & 29 & 59 & 15.1 & 197 & 70 \\
\hline 14.9 & 40 & 62 & 15.1 & 205 & 75 \\
\hline 14.9 & 59 & 61 & & & \\
\hline 14.9 & 43 & 60 & & & \\
\hline 14.9 & 57 & 88 & & & \\
\hline 14.9 & 72 & 69 & & & \\
\hline 14.9 & 101 & 90 & & & \\
\hline 14.9 & 89 & 90 & & & \\
\hline 14.9 & 95 & 90 & & & \\
\hline 14.9 & 64 & 54 & & & \\
\hline
\end{tabular}

Table B6. Foliation orientation data for outcrop 14.9.

\begin{tabular}{|l|r|r|}
\hline Site & Strike & Dip \\
\hline 14.9 & 253 & 59 \\
\hline 14.9 & 257 & 72 \\
\hline 14.9 & 86 & 75 \\
\hline 14.9 & 97 & 76 \\
\hline
\end{tabular}




\section{Appendix C - Additional Stereonet Graphs}
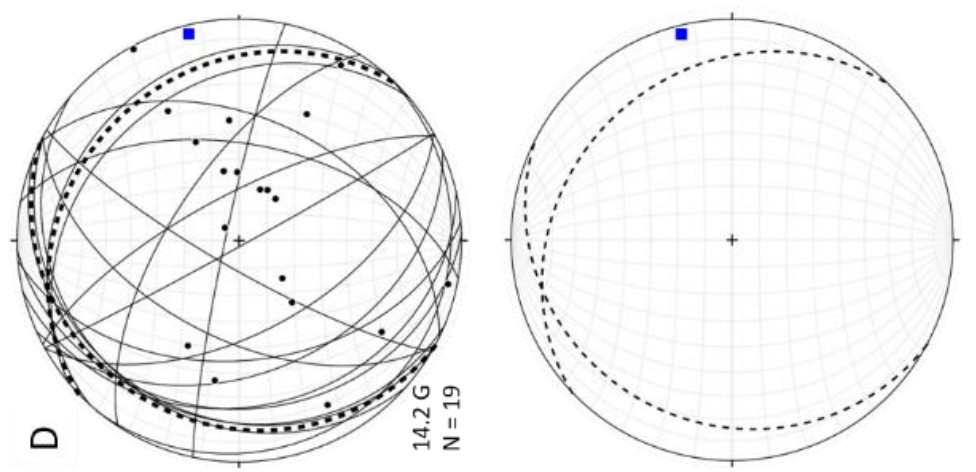

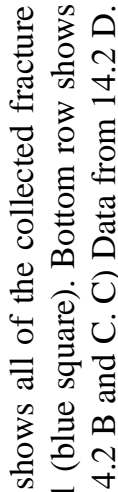
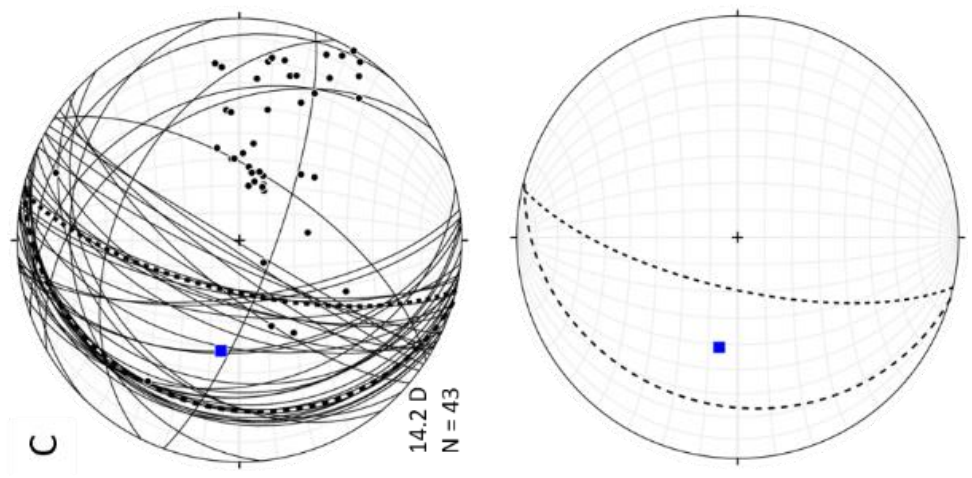

วิ

oे

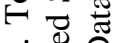

恼壱

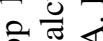

官

氬 灾

छิ

党

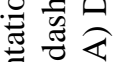
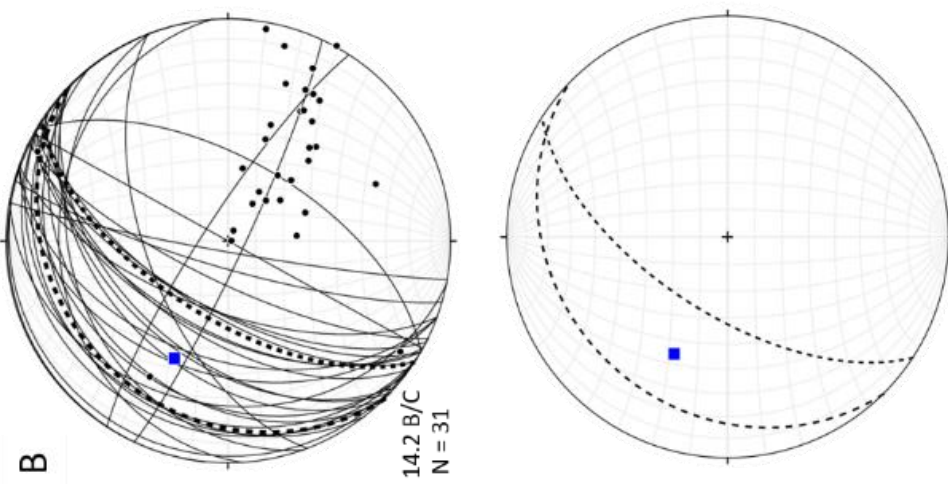

훙 형

齐嵒

可

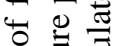

氖

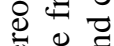

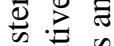

氙

远
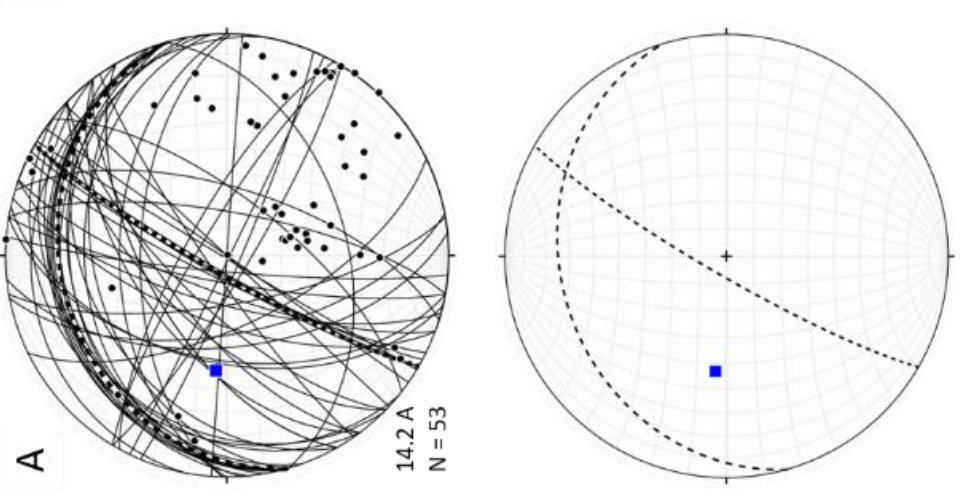

递.

里

$\vec{D}=$

定

$\widetilde{0}$

ป

茟范

I

ப் $\vec{\Xi}$

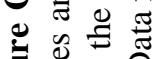

些究合 


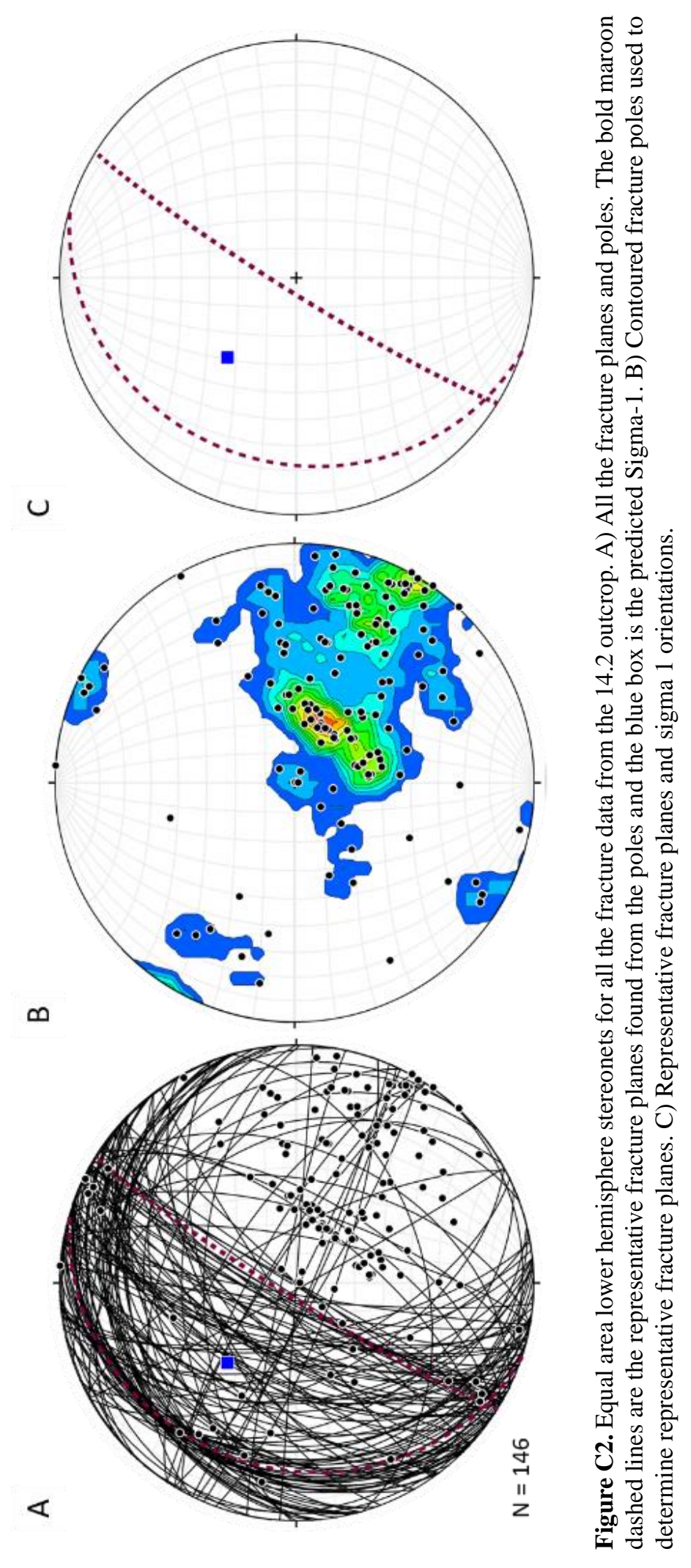




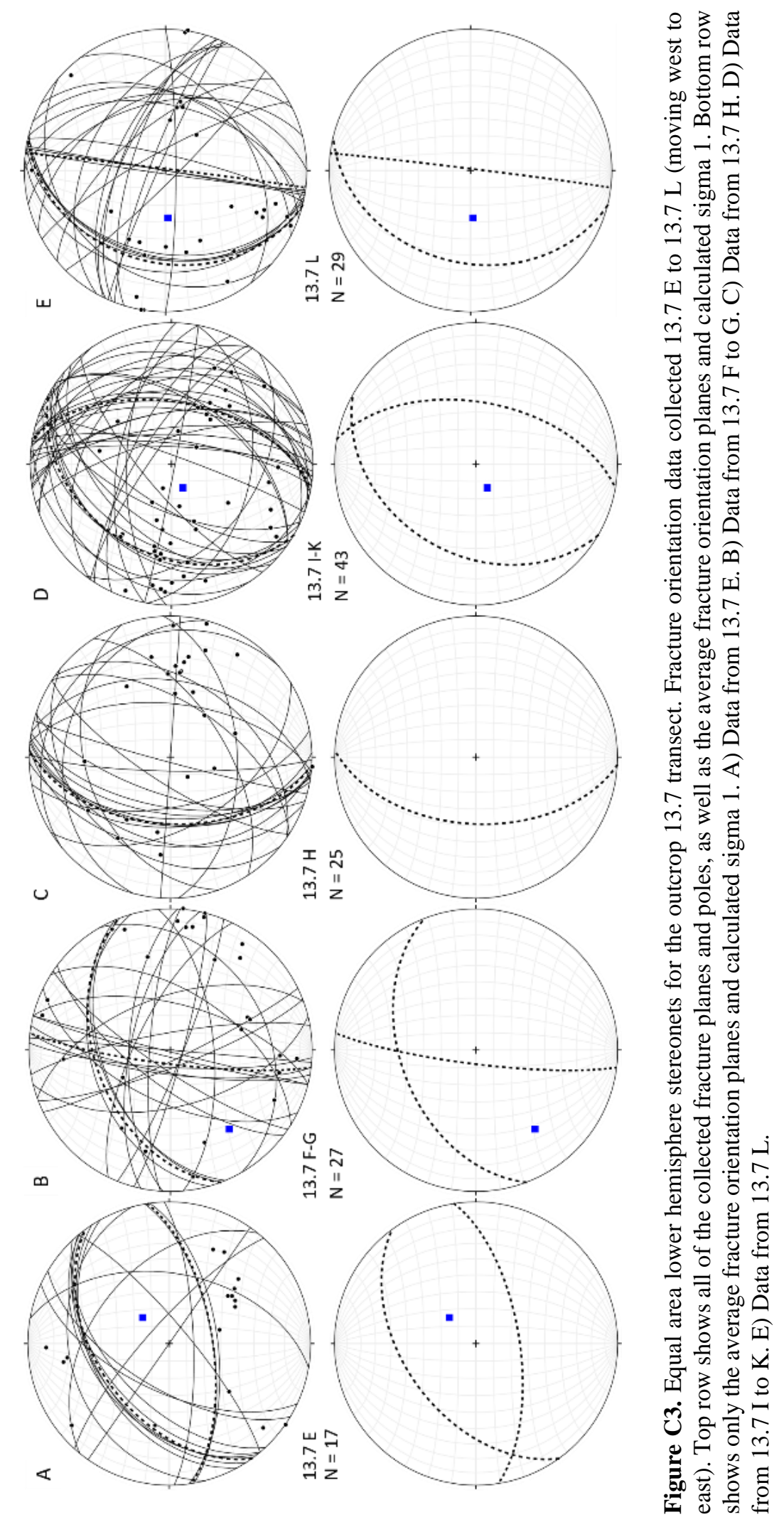

111 


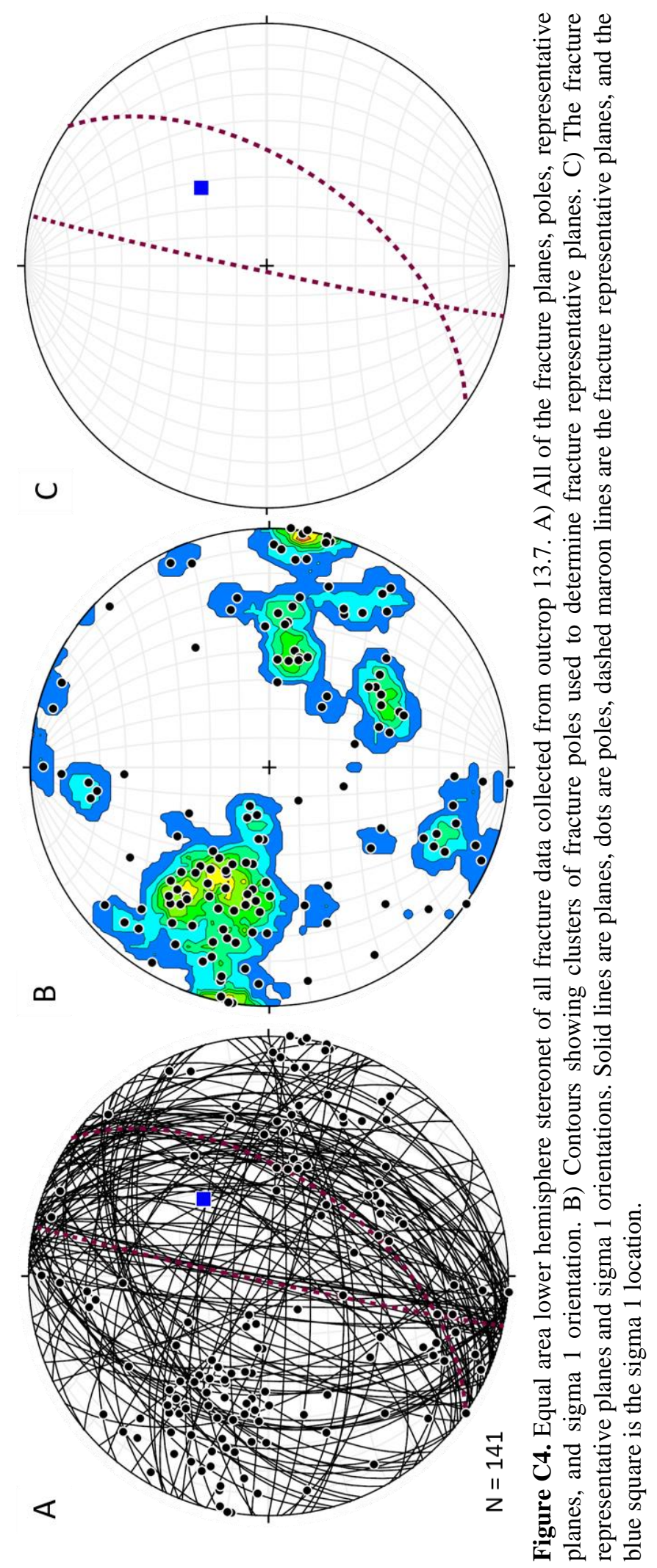

112 

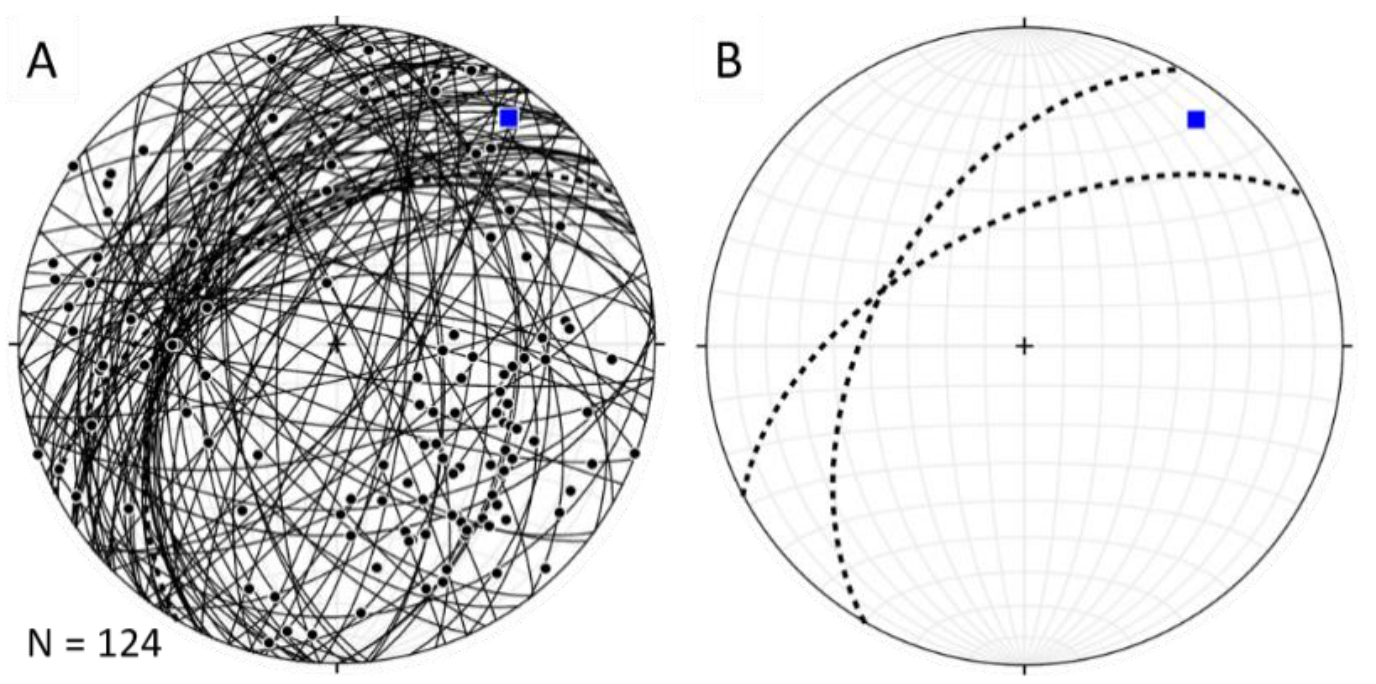

Figure C5. Fracture data for outcrop 11.8. A) Fracture planes (black line) and poles (black dots). B) Representative fracture planes (dashed lines) and predicted Sigma-1 orientation (blue square in A, B). Data are plotted on an equal area lower hemisphere stereonet.
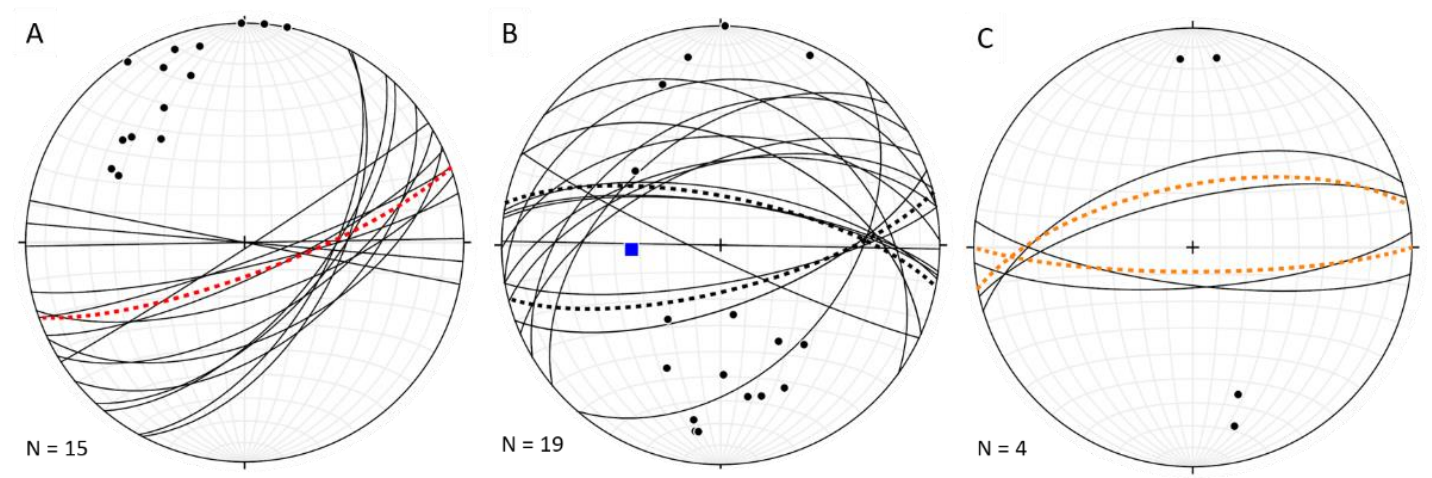

Figure C6. Equal area lower hemisphere stereonets of structural data from outcrop 14.9. For all stereonets: black lines are strike and dip planar measurements, black dots are poles to the planes. A) Bedding orientations. The red dashed line is the representative bedding plane. B) Fracture orientations. Black dashed lines are the representative fracture planes. The blue square is the predicted Sigma-1. C) Foliation orientations. Orange dashed lines are the representative foliation planes. 


\section{Appendix D - Additional Fracture Density Data and Graphs}

Table D1. The Structure from Motion derived fracture per square meter fracture density.

\begin{tabular}{|c|c|c|c|c|c|c|c|c|c|}
\hline \multicolumn{10}{|c|}{ Structure from Motion - Number of Fractures per square meter } \\
\hline \multirow[b]{2}{*}{ Outcrop } & \multirow{2}{*}{$\begin{array}{l}\text { Outcrop } \\
\text { Section } \\
\text { Column }\end{array}$} & \multicolumn{2}{|c|}{ All Fractures } & \multicolumn{2}{|c|}{$\begin{array}{c}\text { NS and EW } \\
\text { Fractures }\end{array}$} & \multicolumn{2}{|c|}{ NS Fractures } & \multicolumn{2}{|c|}{ EW Fractures } \\
\hline & & Counts & Range & Counts & Range & Counts & Range & Counts & Range \\
\hline 14.2 & A1 & 5.7 & 7.0 & 4.3 & 1.0 & 2.3 & 1.0 & 2.0 & 0.0 \\
\hline 14.2 & $\mathrm{~A} 2$ & 3.7 & 4.0 & 3.7 & 4.0 & 2.0 & 2.0 & 1.7 & 2.0 \\
\hline 14.2 & B1 & 35.0 & 0.0 & 18.0 & 0.0 & 14.0 & 0.0 & 4.0 & 0.0 \\
\hline 14.2 & B2 & 11.0 & 0.0 & & 0.0 & & 0.0 & & 0.0 \\
\hline 14.2 & $\mathrm{C} 1$ & 5.0 & 8.0 & 5.0 & 8.0 & 2.5 & 3.0 & 2.5 & 5.0 \\
\hline 14.2 & $\mathrm{C} 2$ & 6.3 & 4.0 & 6.3 & 7.0 & 3.0 & 2.0 & 3.3 & 6.0 \\
\hline 14.2 & $\mathrm{C3}$ & 4.0 & 0.0 & 2.5 & 1.0 & 1.5 & 1.0 & 1.0 & 0.0 \\
\hline 14.2 & $\mathrm{C} 4$ & 7.0 & 3.0 & 6.7 & 4.0 & 3.3 & 2.0 & 3.3 & 3.0 \\
\hline 14.2 & $\mathrm{D} 1$ & 3.7 & 3.0 & 3.7 & 3.0 & 1.0 & 0.0 & 2.7 & 3.0 \\
\hline 14.2 & D2 & 3.0 & 2.0 & 3.0 & 2.0 & 1.0 & 2.0 & 2.0 & 0.0 \\
\hline 13.7 & E1 & 11.0 & 9.0 & 8.7 & 7.0 & 3.7 & 4.0 & 5.0 & 2.0 \\
\hline 13.7 & $\mathrm{E} 2$ & 10.3 & 12.0 & 7.3 & 7.0 & 4.3 & 4.0 & 3.0 & 3.0 \\
\hline 13.7 & E3 & 7.0 & 2.0 & 6.0 & 2.0 & 3.0 & 0.0 & 3.0 & 2.0 \\
\hline 13.7 & E4 & 8.0 & 8.0 & 4.7 & 6.0 & 3.0 & 2.0 & 1.7 & 4.0 \\
\hline 13.7 & F1 & 9.0 & 6.0 & 5.0 & 3.0 & 2.7 & 1.0 & 2.7 & 1.0 \\
\hline 13.7 & $\mathrm{~F} 2$ & 8.7 & 7.0 & 5.7 & 6.0 & 3.3 & 3.0 & 2.3 & 3.0 \\
\hline 13.7 & G1 & 22.7 & 17.0 & 9.7 & 7.0 & 3.3 & 2.0 & 6.3 & 5.0 \\
\hline 13.7 & $\mathrm{G} 2$ & 13.7 & 9.0 & 9.3 & 5.0 & 3.7 & 1.0 & 5.7 & 4.0 \\
\hline 13.7 & G3 & 16.0 & 14.0 & 7.3 & 4.0 & 3.7 & 5.0 & 3.7 & 7.0 \\
\hline 13.7 & G4 & 10.7 & 10.0 & 5.7 & 2.0 & 2.3 & 4.0 & 3.3 & 2.0 \\
\hline 13.7 & $\mathrm{H} 1$ & 15.7 & 9.0 & 10.7 & 9.0 & 7.7 & 11.0 & 3.0 & 2.0 \\
\hline 13.7 & $\mathrm{H} 2$ & 17.0 & 11.0 & 13.3 & 13.0 & 8.3 & 8.0 & 5.0 & 5.0 \\
\hline 13.7 & $\mathrm{H} 3$ & 22.3 & 3.0 & 13.3 & 6.0 & 7.3 & 1.0 & 6.0 & 6.0 \\
\hline 13.7 & $\mathrm{H} 4$ & 14.0 & 17.0 & 13.0 & 12.0 & 8.0 & 3.0 & 5.0 & 9.0 \\
\hline 13.7 & 11 & 12.0 & 10.0 & 5.7 & 6.0 & 4.3 & 2.0 & 1.3 & 4.0 \\
\hline 13.7 & 12 & 17.0 & 5.0 & 5.3 & 3.0 & 3.3 & 4.0 & 2.0 & 3.0 \\
\hline 13.7 & 13 & 9.7 & 8.0 & 4.7 & 3.0 & 1.3 & 1.0 & 3.3 & 3.0 \\
\hline 13.7 & 14 & 10.3 & 14.0 & 6.0 & 7.0 & 3.7 & 7.0 & 2.3 & 2.0 \\
\hline 13.7 & 15 & 12.7 & 9.0 & 5.0 & 5.0 & 2.7 & 3.0 & 2.3 & 2.0 \\
\hline 13.7 & $\mathrm{~J} 1$ & 10.3 & 11.0 & 1.5 & 1.0 & 1.0 & 2.0 & 0.5 & 1.0 \\
\hline 13.7 & $\mathrm{~J} 2$ & 5.0 & 5.0 & 6.0 & 0.0 & 3.0 & 0.0 & 3.0 & 0.0 \\
\hline 13.7 & K1 & 7.0 & 7.0 & 3.3 & 1.0 & 2.0 & 2.0 & 1.3 & 1.0 \\
\hline 13.7 & $\mathrm{~K} 2$ & 20.0 & 0.0 & 3.0 & 0.0 & 3.0 & 0.0 & 0.0 & 0.0 \\
\hline 13.7 & K3 & 21.0 & 0.0 & 2.0 & 0.0 & 1.0 & 0.0 & 1.0 & 0.0 \\
\hline 13.7 & L1 & 30.0 & 12.0 & 7.5 & 3.0 & 3.5 & 1.0 & 4.0 & 2.0 \\
\hline
\end{tabular}




\begin{tabular}{|r|l|r|r|r|r|r|r|r|r|}
\hline 13.7 & L2 & 15.0 & 12.0 & 9.0 & 12.0 & 3.3 & 3.0 & 5.7 & 11.0 \\
\hline 13.7 & L3 & 24.0 & 12.0 & 14.0 & 2.0 & 7.5 & 1.0 & 6.0 & 0.0 \\
\hline 11.8 & C1 & 14.0 & 0.0 & 14.0 & 0.0 & 13.0 & 0.0 & 1.0 & 0.0 \\
\hline 11.8 & D1 & 8.0 & 0.0 & 8.0 & 0.0 & 6.0 & 0.0 & 2.0 & 0.0 \\
\hline 11.8 & E/F1 & 5.0 & 0.0 & 3.0 & 0.0 & 1.0 & 0.0 & 2.0 & 0.0 \\
\hline 11.8 & E/F2 & 10.0 & 0.0 & 5.5 & 5.0 & 3.0 & 2.0 & 2.5 & 3.0 \\
\hline 11.8 & G1 & 4.0 & 2.0 & 3.3 & 2.0 & 2.0 & 2.0 & 1.3 & 1.0 \\
\hline 11.8 & G2 & 4.3 & 6.0 & 3.0 & 4.0 & 1.7 & 2.0 & 1.3 & 3.0 \\
\hline
\end{tabular}

Table D2. Fracture per meter derived from both Structure from Motion and in-situ methods.

\begin{tabular}{|c|c|c|c|c|}
\hline \multicolumn{5}{|c|}{ Fractures per Meter } \\
\hline \multirow{2}{*}{$\begin{array}{l}\text { Outcrop Section } \\
\text { Column }\end{array}$} & \multirow{2}{*}{\multicolumn{2}{|c|}{$\begin{array}{c}\text { SfM } \\
\text { Avg Counts }\end{array}$}} & \multicolumn{2}{|l|}{ In-Situ } \\
\hline & & & Avg Counts & Range \\
\hline 15.1 & & & 10.5 & 1.0 \\
\hline 14.9 & & & 10.5 & 6.0 \\
\hline $14.2 \mathrm{~A}$ & 8.0 & 0.0 & & \\
\hline $14.2 \mathrm{~B}$ & 23.0 & 1.0 & & \\
\hline $14.2 \mathrm{C}$ & 6.0 & 3.0 & 24.3 & 8.0 \\
\hline 14.2 D & 10.0 & 2.0 & 18.6 & 18.0 \\
\hline $14.2 \mathrm{G}$ & & & 26.0 & 24.0 \\
\hline $13.7 \mathrm{C}$ & & & 8.5 & 5.0 \\
\hline $13.7 \mathrm{E}$ & 12.0 & 7.0 & 13.5 & 15.0 \\
\hline $13.7 \mathrm{~F}$ & 12.0 & 2.0 & 8.9 & 12.0 \\
\hline $13.7 \mathrm{G}$ & 22.0 & 4.0 & 14.6 & 14.0 \\
\hline $13.7 \mathrm{H}$ & 23.0 & 6.3 & 17.4 & 14.0 \\
\hline $13.7 \mathrm{I}$ & 16.0 & 2.0 & 16.5 & 12.0 \\
\hline $13.7 \mathrm{~J}$ & 7.0 & 0.0 & 14.5 & 9.0 \\
\hline $13.7 \mathrm{~K}$ & 16.0 & 4.0 & 19.5 & 1.0 \\
\hline $13.7 \mathrm{~L}$ & 29.0 & 3.0 & 18.0 & 20.0 \\
\hline $11.8 \mathrm{~B}$ & & & 9.0 & 0.0 \\
\hline $11.8 \mathrm{C}$ & 14.0 & 0.0 & 11.0 & 6.0 \\
\hline $11.8 \mathrm{D}$ & 8.0 & 0.0 & 5.5 & 1.0 \\
\hline $11.8 \mathrm{E} \& \mathrm{~F}$ & 8.0 & 1.0 & & \\
\hline $11.8 \mathrm{E}$ & & & 7.7 & 13.0 \\
\hline $11.8 \mathrm{~F}$ & & & 7.8 & 5.0 \\
\hline $11.8 \mathrm{G}$ & 6.0 & 2.0 & 5.6 & 9.0 \\
\hline
\end{tabular}




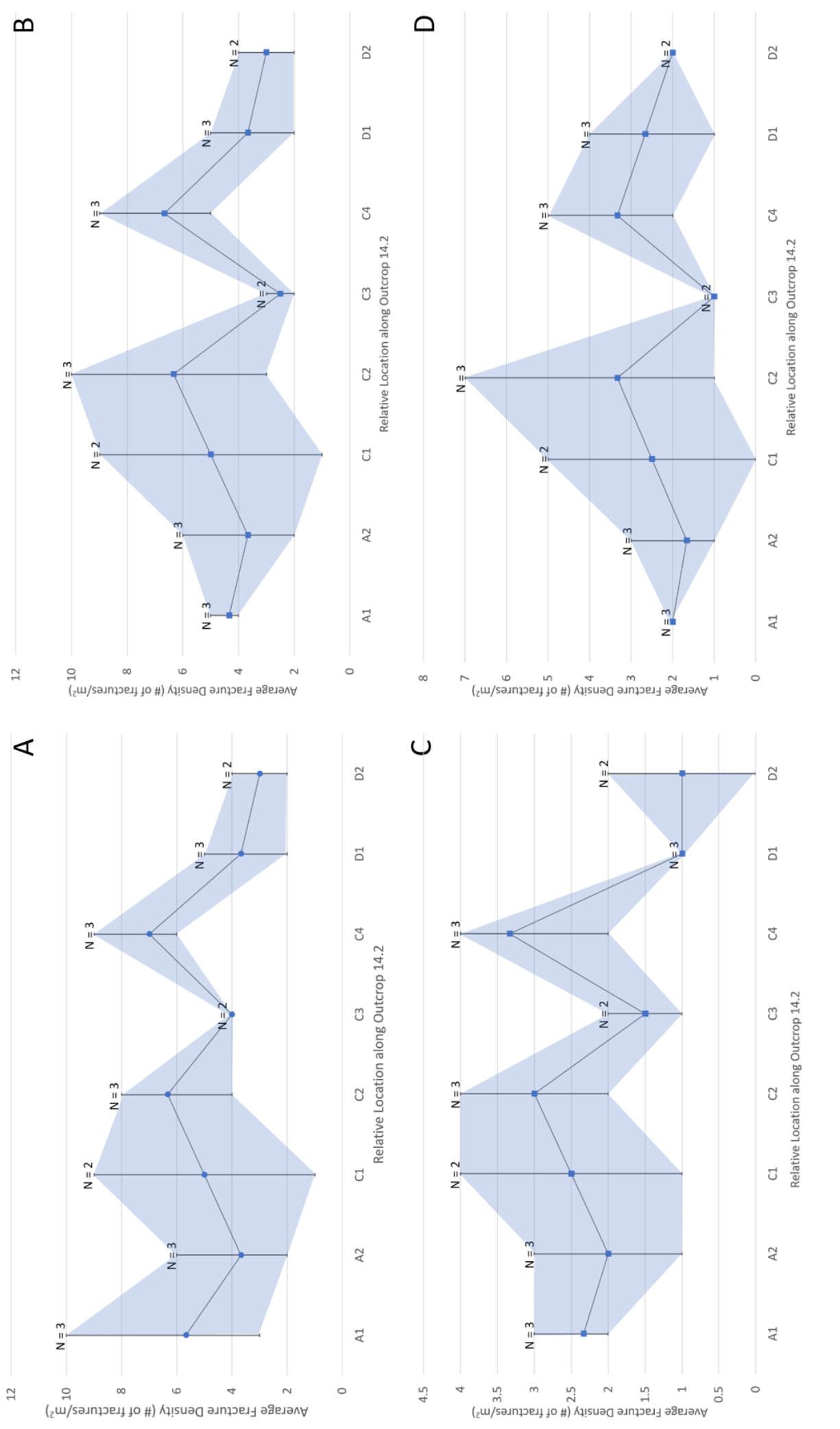

116 \&o

$\stackrel{0}{\mathrm{a}}$

巳 $\dot{\overline{0}}$

各泀总

$\therefore$ : 00

辛 㐘

쿵

要至

包苍

نु ठे

更

응

응

ᄒ 클

윰

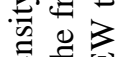

巳

을

픔

ฮิ

总客富

$\Xi 0$

昆

ఫे

उ

的

응

.气

$\sum$ के

ह 든

家

害

ฮี

战。

卷 :

.

응 뭉

楁

ㄷํㅇ

号 勇

○

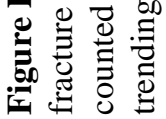



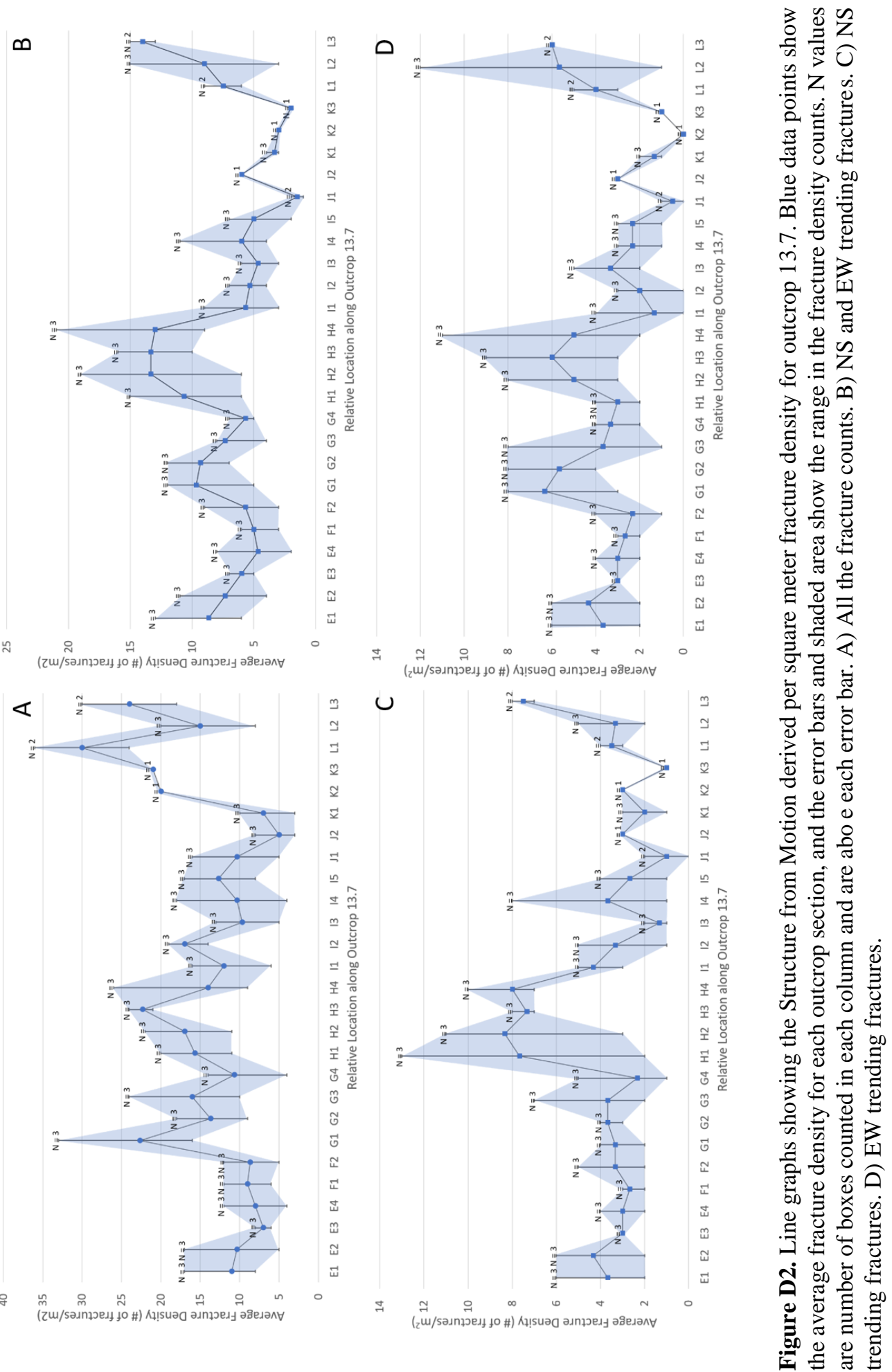


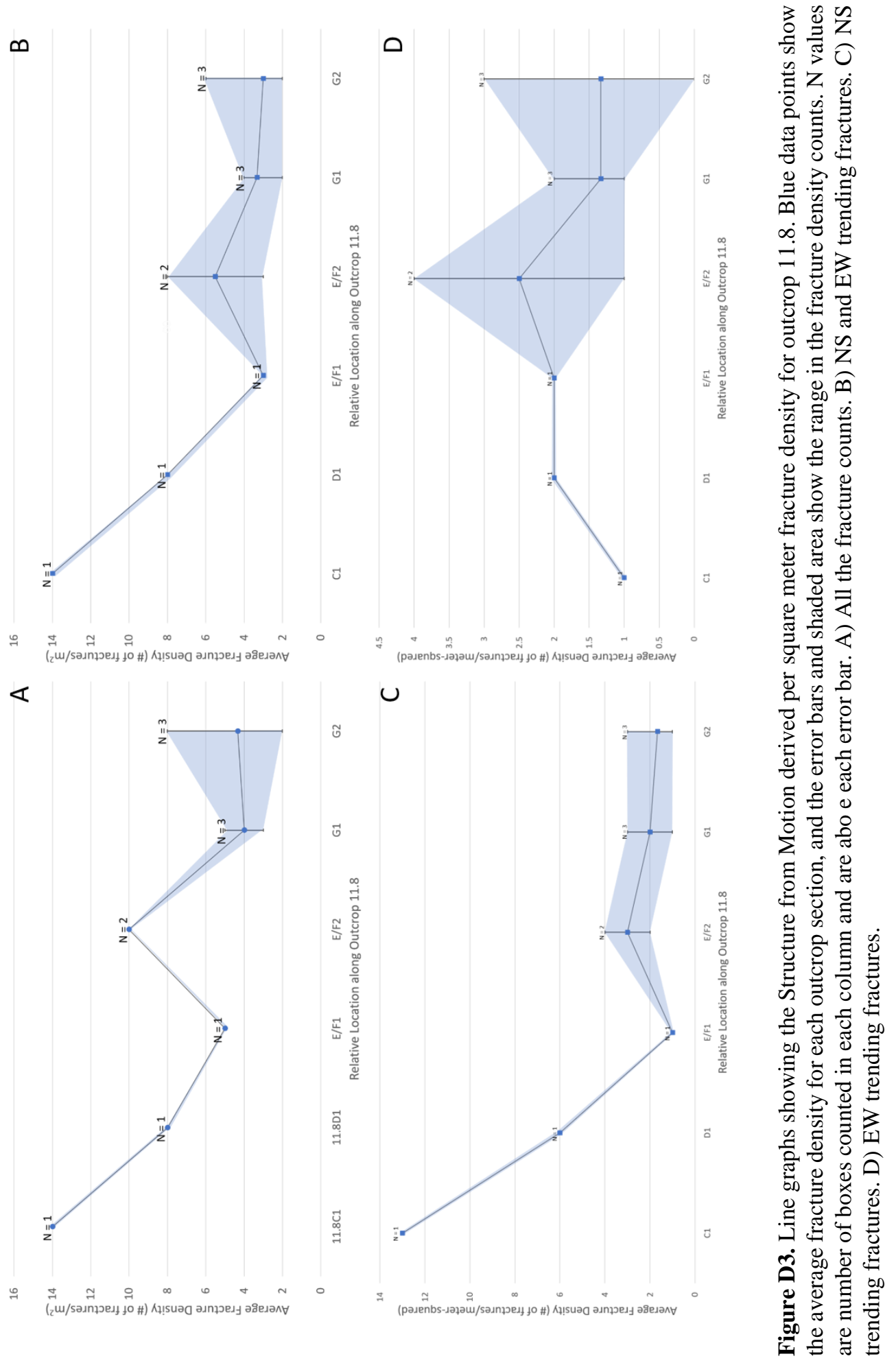

